\title{
ZS Research Suare \\ Ethnobotanical Survey of Medicinal Herbs in the Western Region in Syria (Latakia and Tartus)
}

Chadi Khatib ( $\square$ chadi.khatib@gmail.com )

Damascus University https://orcid.org/0000-0002-4061-1506

Abdulhakim Nattouf

Damascus University

Mohamad Isam Hasan Agha

Damascus University

\section{Research Article}

Keywords: Traditional Arabic Medicine (TAM), herbal medicine, Mediterranean, phytotherapy, medicinal plants, folk uses, ethnobotanical, ethnopharmacology

Posted Date: March 31st, 2021

DOI: https://doi.org/10.21203/rs.3.rs-355008/v1

License: (a) (i) This work is licensed under a Creative Commons Attribution 4.0 International License. Read Full License 


\section{Abstract}

Context

The use of traditional Arabic medicine (TAM) has spread to treat various diseases in Syria since ancient time. They are cost-effective with fewer side effects and are more suitable for long-term use compared with chemically synthesized medicines.

Objective

We conducted ethnobotanical and ethno-medicine research on plants traditionally used to treat various diseases in Western region of Syria.

Methods

Field surveys were conducted during July 2019-December 2020 to document ethnobotanical information through oral interviews and designed semi-structured questionnaire from local herbalists (Tabib Arabi) and the elderly people and others who were familiar with traditional uses of plants particularly for medicinal. The queries were repeatedly made to increase the reliability of the data, during the field survey of 475 local inhabitants of 70 villages.

Results

In this research we listed 258 medicinal plants belonging to 83 families in alphabetical order with the parts used and the method of preparation according to their therapeutic use. Of these studied plants, 185 are used to treat digestive disorders, 118 for respiratory diseases, 91 for several skin diseases, 87 for kidney and urinary tract disorders, 78 for diabetes, 18 for nervous system disorders, and a few plants for treatment the other diseases which are commonly spread in study area. The calculated results of medicinal use-value (MUV) showed that Olea europaea L., Origanum syriacum L. was ranked first (MUV=0.934), while the lowest value was found for Fumana thymifolia (L.) Spach and Cistus creticus L. (MUV=0.003).

Conclusion

A large portion of the uses of medicinal plants mentioned in the research are still under study. There is no doubt that its study will provide many new data that could contribute to further pharmacological discoveries by identifying the active ingredients and their mechanism of effect by doing a lot of pharmacological work to confirm the alleged biological activities of these plants.

\section{Introduction}

Traditional medicine (TM), as defined by the World Health Organization (WHO), is the sum total of the knowledge, skills, and practices based on the theories, beliefs, and experiences indigenous to different cultures, whether explicable or not, used in the maintenance of health as well as in the prevention, diagnosis, improvement, or treatment of physical and mental illness. Some traditional medicine systems are supported by huge volumes of literature and records of the theoretical concepts and practical skills; others pass down 
from generation to generation through verbal teaching. To date, in some parts of the world, the majority of the population continue to rely on their own traditional medicine to meet their primary health care needs. When adopted outside of its traditional culture, traditional medicine is often referred as "complementary and alternative medicine (CAM)" (Che et al. 2017). In the Physicians' Desk Reference (PDR) for herbal medicines, the popular uses of plants are called public uses (Montvale 2000, p.1). TM is often the first choice for providing primary health care in developing countries, and the WHO estimates that more than $80 \%$ of healthcare needs in these countries are met by traditional health care practices, being the cheapest and most accessible (WHO 2002, 2004, 2005). So that the WHO paid special attention to traditional medicine, and it issued its strategy for traditional (folk medicine) 2014-2023 (WHO 2013).

Ethnobotany is the scientific study of the relationships between people and plants. It was first coined in 1896 by the US botanist John Harshberger; however, the history of ethnobotany began long before that (Amjad et al. 2015, Mahmood et al. 2011, Campbell et al. 2002). It plays an important role in understanding the dynamic relationships between biological diversity and social and cultural systems (Amjad et al. 2015, Husain et al. 2008, Amjad et al. 2013). Plants are essential for human beings as they provide food, and medicines(Hameed et al. 2011, Alam et al. 2011, Ahmad et al. 2012). Ethnobotanical approaches are significant in highlighting locally important plant species, particularly for new crude drug sources; Documentation of indigenous knowledge, particularly medicinal values of plant species, provided various modern drugs (Amjad et al. 2015). The indigenous medicinal information of plants is also helpful to ecologists, pharmacologists, taxonomists, watershed and wild life managers in enhancing the prosperity of an area, besides listing the traditional uses (Mahmood et al. 2011, Ibrar et al. 2007).

Arabic traditional medicine (ATM) is one of the famous traditional medical systems, which is occasionally called Unani medicine, Graeco-Arabic medicine, humoral medicine, or Islamic medicine. The subject of traditional medicine in Syria has received little attention in the literature, and very little is known about the traditional medicinal substances used nowadays by the Syrian population to treat the most common diseases.

In 2017 the international center for information and networks for intangible cultural heritage in the Asia-Pacific region (ICHCAP) under the auspices of UNESCO, issued a book entitled Traditional Medicine in which the Syria Trust for Development in Section VII included traditional medicine in Syria within it (Falk et al. 2017).

Syria has a rich diversity of plants that are being used by local communities for medicinal purposes. Proper usages of local plants are common at the community and end-user level. For these reasons, the aim of the present investigation was to gather the uses of medicinal plants in the Western region in Syria (Latakia and Tartus), as a supplement for a national survey, and to document the information concerning the uses of medicinal plants, which may serve as the basis of knowledge for a more intensive scientific research.

\section{Methods}

\subsection{Study area}

Syria, country located on the east coast of the Mediterranean Sea in southwestern Asia. Syria is bounded by Turkey to the north, by Iraq to the east and southeast, by Jordan to the south, and by Lebanon to the 
southwest. The study area is the coast and the western mountains of Syria which is include Latakia governorate and Tartus governorate. (Figure 1).

This area have a Mediterranean climate with a long dry season from May to October. In the extreme northwest there is some light summer rain. On the coast summers are hot, with mean daily maximum temperatures in the low to mid-80s $\mathrm{F}$ (upper 20s C), while the mild winters have daily mean minimum reaching temperatures the low 50s F (low 10s C). Only above about 5,000 feet (1,500 meters) are the summers relatively cool. Inland the climate becomes arid, with colder winters and hotter summers. The coast and western mountains receive 30 to 40 inches (760 to $1000 \mathrm{~mm}$ ) of precipitation annually. Yew, lime, and fir trees grow on the mountain slopes. In coastal region, plants include olive trees, grapevines, apricot trees, oaks, and poplars. Lemon and orange trees grow along the coast (Hamidé et al. 2021).

A reforestation project has been undertaken in the mountains of Latakia and Tartus, and most of forests are protected by the government. Commercially important forest plants include sumac, which is used as a spice, wild pistachio, which is important for its oil-rich fruit, laurel, which is used in the production of cosmetics, and mulberry, whose leaves are fed to silkworms. Pine tree and tobacco. Other useful plants are winter vegetables such as khubbayzah, a kind of spinach; Akkūb, a flowering plant (Hamidé et al. 2021).

The coastal strip is one of the Syria's traditional regions which is cultivated steppe. On the coast the fertile alluvial plains are intensively cultivated in both summer and winter. The region is the site of Syria's two principal ports of Latakia (Al-Lādhiqiyyah) and Tarțūs. In rural areas, work takes place according to the seasonal rhythm of agriculture. Women generally share in much of the agricultural labor (Hamidé et al. 2021).

The Mediterranean port of Latakia is surrounded by a rich agricultural region and contains some industry. Because of its seaside location, the city is a major tourist center (Hamidé et al. 2021).

Agriculture constitutes an important source of income, fruits and vegetables include tomatoes, potatoes, melons, and onions. Olives, grapes, and apples are grown at high altitudes, while citrus fruits are cultivated along the coast. High-grade tobacco is grown in the area around Latakia (Hamidé et al. 2021).

Historically, the ancient Syrian Phoenice in the east coast of the Mediterranean Sea is one of the first civilizations to use alphabets on a large scale.

\subsection{Field work and data collection}

Field surveys were conducted during July 2019-December 2020 to document ethnobotanical information through oral interviews and designed semi-structured questionnaire. 70 villages were visited for field research. 625 people were contacted, and 475 of them accepted to become our informants who have ethnobotanical experience, including local herbalists (Tabib Arabi) and the elderly people and others who were familiar with traditional uses of plants particularly for medicinal. The queries were repeatedly made to increase the reliability of the data. Interviews with the men were usually carried out in the "Mukhtar" house where they come together, and with women in their homes, bazaars and gardens. The Syria trust for development (which is a national development organization, and has a program which is called "Mashrouie" runs innovative microcredit programs that encourage economic growth in disadvantaged areas) helped us in data collecting. 
The information gathered during the present study included socio-demographic characteristics of the interviewed informants (age, gender) and ethnopharmacological information, including the local and scientific name of the species, local names, plant parts used, modes of use, conservation method, administration mode and toxicity, all documented data were then translated into English and Latin.

\subsection{Taxonomic identification of the species}

Medicinal plants being mentioned by the Informants were recorded with local names and photographed. Each reported medicinal plant species was gathered, compressed, dehydrated, mounted on herbarium sheets, and identified, the taxonomic identity of the plants was confirmed by Prof. Abdel Aleem Bello (PhD / Botanical Taxonomy) and Dr. Bayan Tiba (PhD / Botanical Taxonomy) Aleppo university, As far as possible, the name of the plants was updated by consulting the latest literature; generic and species names followed the plant list (http://www.theplantlist.org). All voucher specimens have been preserved during documentation and deposited in the Damascus University, faculty of pharmacy, pharmacognosy labs Herbarium for future reference.

\subsection{Ethics approval and consent to participate}

The study was approved by the Ethics Committee of the University of Damascus. Before beginning data collection, we obtained verbal informed permission in each case site-wide and then individually before each interview. We also informed informants that it was an academic project and that the investigation was for research purposes only, and not for any financial or other benefits. Informants provided verbal informed consent to participate in this study; They were free to withdraw their information at any time. These informants freely accepted the interview.

\subsection{Consent for publication}

The study has a consent for publication by the faculty of pharmacy - University of Damascus on 7/3/2021 .

\subsection{Data analysis}

The data collected through interviews of the informants were classified and examined with the statistical program IBM ${ }^{\circledR}$ SPSS ${ }^{\circledR}$ Statistics 26 , to determine the proportions of different variables such as ethnopharmacological data. Quantitative value indices were analyzed using different statistical quantitative tools i.e. the use reports (UR) of a species, and medicinal use value (MUV) (Chaachouaya et al. 2021).

\section{Medicinal use-value (MUV) and use reports (UR)}

The use reports (UR) of a species or its importance in the culture of a community is denoted by its mentioning rate or its mention frequency by informants. The UR of the species of plants being utilized was evaluated using the formula (Tenté et al 2012):

$\mathrm{UR}=\mathrm{Ni} / \mathrm{n}$

$\mathrm{Ni}$ : the number of times a particular species was mentioned 
$\mathrm{n}$ : the total number of times that all species were mentioned

The MUV of recorded medicinal plants was determined by applying the following formula (Tabuti et al. 2003):

MUV $=\sum U R i / N$

$\sum$ URi: the total number of use reports per plants

$\mathrm{N}$ : the total of interviewees questioned for given medicinal species

The MUV rate will be more important if there are several useful records for a species, implying that the plant is significant, whereas they will be near 0 if there are few reports compared to its use (Chaachouaya et al. 2021, Yaseen et al. 2015).

\section{Results}

\subsection{Demographic data of informants}

In total, 475 local inhabitants of 70 villages were selected based on their experience in traditional uses of plants particularly for medicinal, (Table 1) show the age and gender wise distribution. All of them were interrogated using semi-structured questionnaires. Generally in Syria, both genders were interested in herbal medicines. While in the countryside (the study area), women are more interested in livelihood, treatment, plant collection and processing compared to men, so that the percentage of informants was $54.94 \%$ females, $45.05 \%$, males, and most of them were older than 50 years.

Table 1: Age and gender wise distribution

\begin{tabular}{|c|c|c|}
\hline Age Group & Gender & No. of Informants \\
\hline \multirow[t]{2}{*}{ Old (50+) } & Male & 145 \\
\hline & Female & 163 \\
\hline \multirow[t]{2}{*}{ Middle age $(25+)$} & Male & 65 \\
\hline & Female & 85 \\
\hline \multirow[t]{2}{*}{ Youngster } & Male & 4 \\
\hline & Female & 13 \\
\hline Total & & 475 \\
\hline
\end{tabular}

\subsection{Ethnobotanical uses of plant species}

A total of 258 plant species belonging to 83 families are recorded in the present study, which are being used for a variety of purposes by native people. The detailed inventory is provided in Table 2, which includes botanical names, followed by local name, family and ethnobotanical uses. 
Table 2: Ethnobotanical uses of plant species according to ethnomedicinal survey of Western region in Syria (Latakia and Tartus). 


\begin{tabular}{|c|c|c|c|c|c|c|}
\hline No. & $\begin{array}{l}\text { Name of } \\
\text { Species }\end{array}$ & $\begin{array}{l}\text { Common } \\
\text { Name (Arabic } \\
\text { Language) }\end{array}$ & Family & $\begin{array}{l}\text { Part } \\
\text { Used }\end{array}$ & MUV & Ethnobotanical Uses \\
\hline 1. & $\begin{array}{l}\text { Abies cilicica } \\
\text { (Antoine \& } \\
\text { Kotschy) } \\
\text { Carrière }\end{array}$ & वस्पा (Shouh) & Pinaceae & Rs & 0.036 & $\begin{array}{l}\text { An aromatic oil and } \\
\text { the resin is used } \\
\text { externally as an } \\
\text { antiseptic, it helps in } \\
\text { relaxing the muscles, } \\
\text { and to rid of } \\
\text { unpleasant odors of } \\
\text { the body. }\end{array}$ \\
\hline 2. & $\begin{array}{l}\text { Acanthus } \\
\text { syriacus boiss. }\end{array}$ & 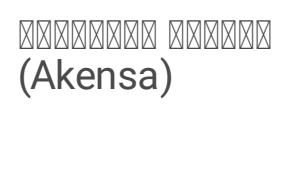 & Acanthaceae & $\mathrm{L}$ & 0.018 & $\begin{array}{l}\text { An infusion of the } \\
\text { leaves is used } \\
\text { externally to ease } \\
\text { irritation }\end{array}$ \\
\hline 3. & $\begin{array}{l}\text { Acer syriacum } \\
\text { Boiss. \& Gaill. }\end{array}$ & 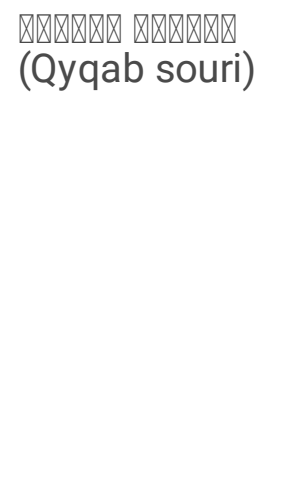 & Aceraceae & $\mathrm{F}$ & 0.09 & $\begin{array}{l}\text { Sugary maple juice is } \\
\text { produced in a } \\
\text { primitive way, by } \\
\text { inserting tubes into } \\
\text { the tree trunk on } \\
\text { spring days between } \\
\text { February and March, } \\
\text { Maple fruits are used } \\
\text { to treat diabetes, } \\
\text { urinary infections, } \\
\text { and prostate } \\
\text { disorders. }\end{array}$ \\
\hline 4. & $\begin{array}{l}\text { Achillea } \\
\text { falcata } \mathrm{L} .\end{array}$ & 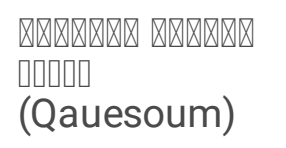 & Asteraceae & $\mathrm{R}$ & 0.181 & $\begin{array}{l}\text { A decoction of roots } \\
\text { is used as diuretic. }\end{array}$ \\
\hline 5. & $\begin{array}{l}\text { Achillea } \\
\text { fragrantissima } \\
\text { (Forssk.) Sch. } \\
\text { Bip. }\end{array}$ & प्राप्र (Alphieh) & Asteraceae & L & 0.072 & $\begin{array}{l}\text { An infusion of the } \\
\text { leaves is used for } \\
\text { fever, common cold, } \\
\text { hay fever, absence of } \\
\text { menstruation, } \\
\text { dysentery, diarrhea, } \\
\text { loss of appetite, } \\
\text { gastrointestinal (GI) } \\
\text { tract discomfort, and } \\
\text { to induce sweating. }\end{array}$ \\
\hline 6. & $\begin{array}{l}\text { Achillea } \\
\text { millefolium } \mathrm{L} .\end{array}$ & 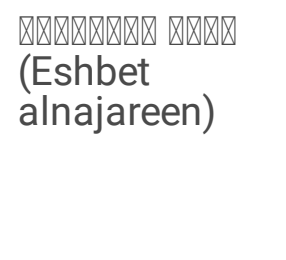 & Asteraceae & $\mathrm{L}, \mathrm{Fl}$ & 0.127 & $\begin{array}{l}\text { An infusion of the } \\
\text { leaves and flowers is } \\
\text { used for asthma and } \\
\text { common cold, and } \\
\text { for treat urinary } \\
\text { infections. }\end{array}$ \\
\hline
\end{tabular}




\begin{tabular}{|c|c|c|c|c|c|c|}
\hline No. & $\begin{array}{l}\text { Name of } \\
\text { Species }\end{array}$ & $\begin{array}{l}\text { Common } \\
\text { Name (Arabic } \\
\text { Language) }\end{array}$ & Family & $\begin{array}{l}\text { Part } \\
\text { Used }\end{array}$ & MUV & Ethnobotanical Uses \\
\hline 7. & $\begin{array}{l}\text { Achillea } \\
\text { maritima (L.) } \\
\text { Ehrend. \& } \\
\text { Y.P.Guo }\end{array}$ & प्रापा (Akhelia) & Asteraceae & L & 0.654 & $\begin{array}{l}\text { An infusion of leaves } \\
\text { is used as a cough } \\
\text { suppressant and } \\
\text { expectorant, } \\
\text { anthelmintic, for } \\
\text { varicose veins, } \\
\text { menstrual pain relief, } \\
\text { diuretic, urinary } \\
\text { disinfectant, } \\
\text { hemorrhoids. }\end{array}$ \\
\hline 8. & $\begin{array}{l}\text { Acorus } \\
\text { calamus L. }\end{array}$ & 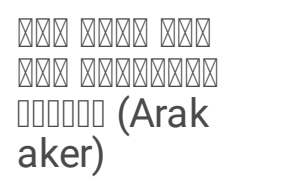 & Acoraceae & $\mathrm{R}$ & 0.134 & $\begin{array}{l}\text { A decoction of roots } \\
\text { is used as diuretic } \\
\text { and tonic. }\end{array}$ \\
\hline 9. & $\begin{array}{l}\text { Adiantum } \\
\text { capillus-veneris } \\
\text { L. }\end{array}$ & 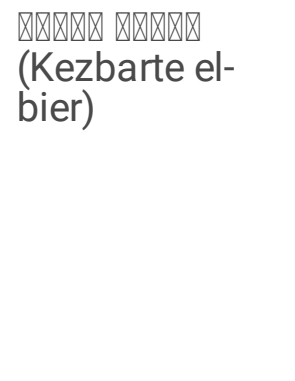 & Pteridaceae & $\mathrm{L}$ & 0.581 & $\begin{array}{l}\text { An infusion of leaves } \\
\text { is used for cleansing } \\
\text { respiratory system, } \\
\text { asthma, and for } \\
\text { gastrointestinal } \\
\text { disorders such as } \\
\text { jaundice, diarrhea, } \\
\text { also it is used as a } \\
\text { diuretic agent. }\end{array}$ \\
\hline 10. & $\begin{array}{l}\text { Aeluropus } \\
\text { lagopoides (L.) } \\
\text { Thwaites }\end{array}$ & 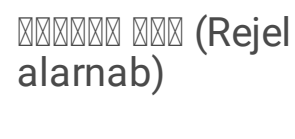 & Poaceae & L & 0.065 & $\begin{array}{l}\text { A fresh green leaves } \\
\text { are used as a tonic. }\end{array}$ \\
\hline 11. & $\begin{array}{l}\text { Agrimonia } \\
\text { eupatoria L. }\end{array}$ & 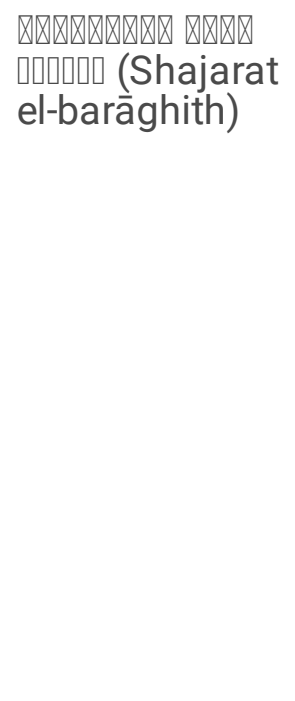 & Rosaceae & W, FI & 0.109 & $\begin{array}{l}\text { An infusion of whole } \\
\text { herb with flowers is } \\
\text { used for cough, } \\
\text { diabetes, diarrhea, } \\
\text { and jaundice, and } \\
\text { used as diuretic, and } \\
\text { infusion of flowers is } \\
\text { used as gargle for the } \\
\text { symptomatic relief of } \\
\text { minor inflammations } \\
\text { of the mouth and } \\
\text { throat, and the } \\
\text { decoction of flowers } \\
\text { is used for skin } \\
\text { diseases anti-itch, } \\
\text { relieve congestion of } \\
\text { hemorrhoids. }\end{array}$ \\
\hline 12. & $\begin{array}{l}\text { Agropyron } \\
\text { junceum (L.) } \\
\text { P.Beauv. }\end{array}$ & 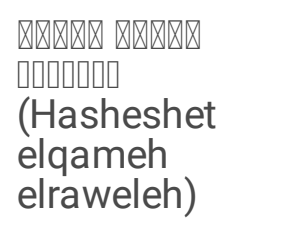 & Poaceae & $\mathrm{R}$ & 0.054 & $\begin{array}{l}\text { A decoction of roots } \\
\text { is used as diuretic. }\end{array}$ \\
\hline
\end{tabular}




\begin{tabular}{|c|c|c|c|c|c|c|}
\hline No. & $\begin{array}{l}\text { Name of } \\
\text { Species }\end{array}$ & $\begin{array}{l}\text { Common } \\
\text { Name (Arabic } \\
\text { Language) }\end{array}$ & Family & $\begin{array}{l}\text { Part } \\
\text { Used }\end{array}$ & MUV & Ethnobotanical Uses \\
\hline 13. & $\begin{array}{l}\text { Alcea setosa } \\
\text { (Boiss.) Alef. }\end{array}$ & प्राप्र (Khetmi) & Malvaceae & $\mathrm{Fl}, \mathrm{W}$ & 0.781 & $\begin{array}{l}\text { An infusion of } \\
\text { flowers is used as } \\
\text { demulcent, } \\
\text { expectorant, diuretic, } \\
\text { emollient, digestive, } \\
\text { decongestant, anti- } \\
\text { rheumatic, the juice } \\
\text { of the plant is used to } \\
\text { treat injuries, burns. }\end{array}$ \\
\hline 14. & $\begin{array}{l}\text { Alchemilla } \\
\text { vulgaris L. }\end{array}$ & 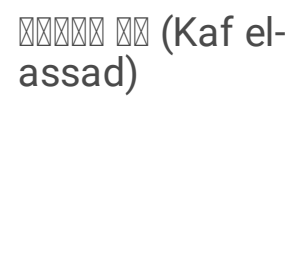 & Rosaceae & Ap & 0.094 & $\begin{array}{l}\text { An infusion of aerial } \\
\text { parts is used for } \\
\text { stomach problems, } \\
\text { mild diarrhea, } \\
\text { diabetes, and anti- } \\
\text { obesity. }\end{array}$ \\
\hline 15. & Allium cepa L. & प्राप्र (Al-basal) & Alliaceae & $\mathrm{Bb}$ & 0.909 & $\begin{array}{l}\text { A juice of the fresh } \\
\text { bulb is used internally } \\
\text { for cough, asthma } \\
\text { attacks, typhoid, and } \\
\text { the roasted bulb is } \\
\text { eaten for diabetes, A } \\
\text { juice of the fresh } \\
\text { bulb is used } \\
\text { externally for } \\
\text { whooping cough, } \\
\text { back pain, neck pain, } \\
\text { and warts. }\end{array}$ \\
\hline 16. & $\begin{array}{l}\text { Allium } \\
\text { trifoliatum } \\
\text { Cirillo }\end{array}$ & 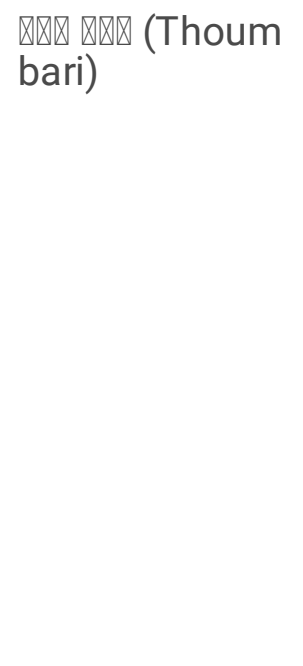 & Alliaceae & $\mathrm{Bb}$ & 0.887 & $\begin{array}{l}\text { Fresh bulb is used for } \\
\text { hypertension } \\
\text { treatment, vermifuge, } \\
\text { diseases of the } \\
\text { gastrointestinal tract, } \\
\text { and urinary tract } \\
\text { infection, relieve } \\
\text { atherosclerosis, } \\
\text { diabetes, anti- } \\
\text { inflammatory, the } \\
\text { bulb oil is used } \\
\text { topical for } \\
\text { rheumatism, } \\
\text { dandruff, scabies, } \\
\text { fungi, and treating } \\
\text { insect bites. }\end{array}$ \\
\hline 17. & $\begin{array}{l}\text { Alnus orientalis } \\
\text { Decne. }\end{array}$ & प्राप्र (Nagat) & Betulaceae & L, Bk & 0.054 & $\begin{array}{l}\text { A decoction of leaves } \\
\text { is used for treatment } \\
\text { of rheumatism, } \\
\text { hemorrhoids and for } \\
\text { wound healing, a } \\
\text { decoction of bark is } \\
\text { used for insect bites, } \\
\text { and skin irritations. }\end{array}$ \\
\hline
\end{tabular}




\begin{tabular}{|c|c|c|c|c|c|c|}
\hline No. & $\begin{array}{l}\text { Name of } \\
\text { Species }\end{array}$ & $\begin{array}{l}\text { Common } \\
\text { Name (Arabic } \\
\text { Language) }\end{array}$ & Family & $\begin{array}{l}\text { Part } \\
\text { Used }\end{array}$ & MUV & Ethnobotanical Uses \\
\hline 18. & $\begin{array}{l}\text { Ammi visnaga } \\
\text { (L.) Lam. }\end{array}$ & 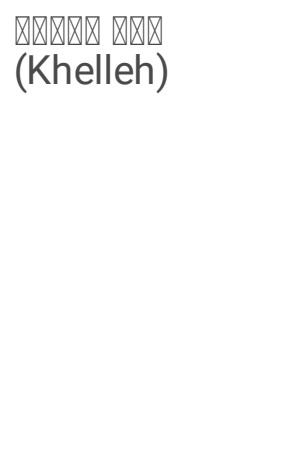 & Apiaceae & $\begin{array}{l}\text { Sk, } \\
\text { Sd }\end{array}$ & 0.872 & $\begin{array}{l}\text { Sticks of this plant } \\
\text { used to clean the } \\
\text { teeth, and seeds } \\
\text { decoction used as a } \\
\text { diuretic, } \\
\text { antispasmodic and } \\
\text { for bladder stones. } \\
\text { Also it is used as a } \\
\text { smooth muscle } \\
\text { relaxant for asthma, } \\
\text { and whooping cough. }\end{array}$ \\
\hline 19. & $\begin{array}{l}\text { Amygdalus } \\
\text { communis L./ } \\
\text { Prunus dulcis } \\
\text { (Mill.) } \\
\text { D.A.Webb }\end{array}$ & 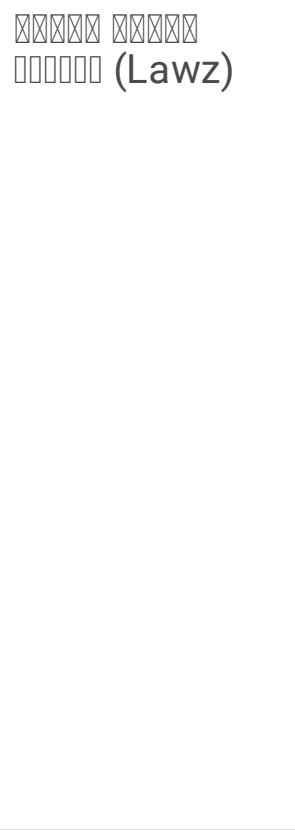 & Rosaceae & Sd & 0.781 & $\begin{array}{l}\text { Sweet almond seed } \\
\text { oil is used internally } \\
\text { for constipation and } \\
\text { for bronchial } \\
\text { diseases and asthma, } \\
\text { and for digestive } \\
\text { system, and } \\
\text { externally the oil is } \\
\text { used for skin } \\
\text { diseases, massage } \\
\text { and to nourish the } \\
\text { skin, also it is used in } \\
\text { traditional recipes for } \\
\text { hair care. } \\
\text { Bitter almond seed oil } \\
\text { is used topically for } \\
\text { increasing hair } \\
\text { growth, and to relieve } \\
\text { mild pain. }\end{array}$ \\
\hline 20. & $\begin{array}{l}\text { Anagallis } \\
\text { arvensis } \mathrm{L} .\end{array}$ & $\begin{array}{l}\text { Q } \\
\text { qet) }\end{array}$ & Primulaceae & Ap & 0.163 & $\begin{array}{l}\text { Despite the toxicity of } \\
\text { the herb, an infusion } \\
\text { of aerial parts is used } \\
\text { to treat rheumatism, } \\
\text { diuretic, expectorant, } \\
\text { and it is also used in } \\
\text { the treatment of gout. }\end{array}$ \\
\hline 21. & $\begin{array}{l}\text { Anchusa } \\
\text { azurea Mill. }\end{array}$ & 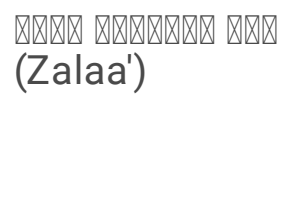 & Boraginaceae & W & 0.218 & $\begin{array}{l}\text { A cooked herb is used } \\
\text { as diuretic in bladder } \\
\text { and kidney stones, } \\
\text { tonic, fever, cough } \\
\text { and asthma. }\end{array}$ \\
\hline
\end{tabular}




\begin{tabular}{|c|c|c|c|c|c|c|}
\hline No. & $\begin{array}{l}\text { Name of } \\
\text { Species }\end{array}$ & $\begin{array}{l}\text { Common } \\
\text { Name (Arabic } \\
\text { Language) }\end{array}$ & Family & $\begin{array}{l}\text { Part } \\
\text { Used }\end{array}$ & MUV & Ethnobotanical Uses \\
\hline 22. & $\begin{array}{l}\text { Anthemis } \\
\text { cotula L. }\end{array}$ & 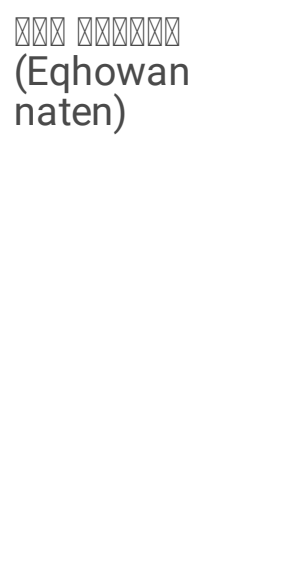 & Asteraceae & $\begin{array}{l}\mathrm{Fl}, \\
\mathrm{Ap}\end{array}$ & 0.09 & $\begin{array}{l}\text { Hot boiled of flowers } \\
\text { is used topically to } \\
\text { treat hemorrhoids } \\
\text { and insect repellent, } \\
\text { and internally for } \\
\text { menstrual cramps } \\
\text { and pain and } \\
\text { intestinal ailments, } \\
\text { The plant is toxic and } \\
\text { causes miscarriage, } \\
\text { an aerial parts } \\
\text { powder is used as a } \\
\text { very effective } \\
\text { insecticide. }\end{array}$ \\
\hline 23. & $\begin{array}{l}\text { Anthemis } \\
\text { tinctoria L. }\end{array}$ & 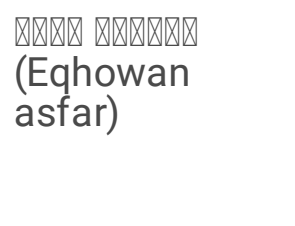 & Asteraceae & $\mathrm{FI}$ & 0.247 & $\begin{array}{l}\text { An infusion of } \\
\text { flowers is used as } \\
\text { diuretic, and for } \\
\text { menstrual, migraine, } \\
\text { and relaxing. }\end{array}$ \\
\hline 24. & $\begin{array}{l}\text { Arachis } \\
\text { hypogaea L. }\end{array}$ & 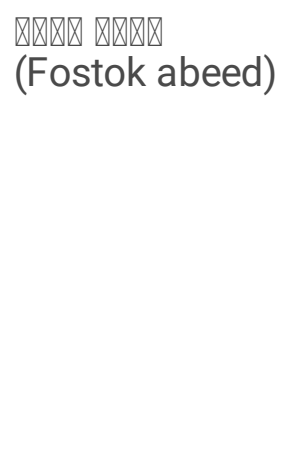 & Fabaceae & Sd & 0.672 & $\begin{array}{l}\text { A seeds are an } \\
\text { important source of } \\
\text { protein used to } \\
\text { provide the body with } \\
\text { energy, peanut butter } \\
\text { is used to improve } \\
\text { mood and reduce } \\
\text { feelings of tiredness } \\
\text { and fatigue, and } \\
\text { stimulate blood } \\
\text { circulation. }\end{array}$ \\
\hline 25. & $\begin{array}{l}\text { Arbutus } \\
\text { andrachne L. }\end{array}$ & प्रा (Katlab) & Ericaceae & $\begin{array}{l}\mathrm{L}, \mathrm{F} \\
\mathrm{R}\end{array}$ & 0.083 & $\begin{array}{l}\text { A decoction of leaves } \\
\text { and fruits is used for } \\
\text { urinary infections and } \\
\text { cystitis and urethritis, } \\
\text { diuretic and as tonic } \\
\text { for digestive system } \\
\text { and antispasmodic, A } \\
\text { decoction of roots is } \\
\text { used for lowering } \\
\text { high blood pressure, } \\
\text { Its ripe fruits are } \\
\text { eaten causing } \\
\text { diarrhea. }\end{array}$ \\
\hline 26. & $\begin{array}{l}\text { Arctium lappa } \\
\text { L. }\end{array}$ & 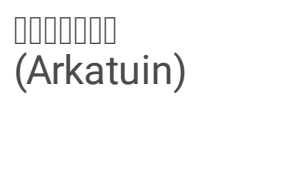 & Asteraceae & $\begin{array}{l}\mathrm{L}, \\
\mathrm{Sd} \\
\mathrm{R}\end{array}$ & 0.098 & $\begin{array}{l}\text { A decoction of leaves } \\
\text { and seeds and roots } \\
\text { is used as diuretic } \\
\text { and for diabetes. }\end{array}$ \\
\hline 27. & $\begin{array}{l}\text { Arisarum } \\
\text { vulgare } \\
\text { O.Targ.Tozz. }\end{array}$ & 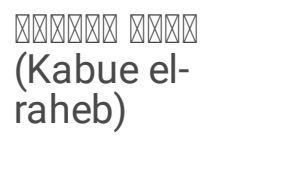 & Araceae & $\mathrm{R}$ & 0.101 & $\begin{array}{l}\text { A decoction of roots } \\
\text { is used for } \\
\text { constipation and } \\
\text { rheumatism. }\end{array}$ \\
\hline
\end{tabular}




\begin{tabular}{|c|c|c|c|c|c|c|}
\hline No. & $\begin{array}{l}\text { Name of } \\
\text { Species }\end{array}$ & $\begin{array}{l}\text { Common } \\
\text { Name (Arabic } \\
\text { Language) }\end{array}$ & Family & $\begin{array}{l}\text { Part } \\
\text { Used }\end{array}$ & MUV & Ethnobotanical Uses \\
\hline 28. & $\begin{array}{l}\text { Aristolochia } \\
\text { sempervirens } \\
\text { L. }\end{array}$ & $\begin{array}{l}\text { (Aretesheh) } \\
\text { (Aretesheh) }\end{array}$ & Aristolochiaceae & $\begin{array}{l}W_{1} \\
\mathrm{Ap}\end{array}$ & 0.203 & $\begin{array}{l}\text { An edible herbs, an } \\
\text { aerial parts are used } \\
\text { as liver tonic. }\end{array}$ \\
\hline 29. & $\begin{array}{l}\text { Armeniaca } \\
\text { vulgaris } \mathrm{L} .\end{array}$ & $\begin{array}{l}\text { (mushamash) } \\
\text { (mula }\end{array}$ & Rosaceae & $\mathrm{F}$ & 0.487 & $\begin{array}{l}\text { Dried Fruits are used } \\
\text { to strengthen the } \\
\text { body's immunity. }\end{array}$ \\
\hline 30. & $\begin{array}{l}\text { Artemisia } \\
\text { herba-alba } \\
\text { Asso. }\end{array}$ & 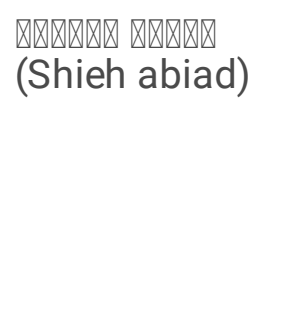 & Asteraceae & $\mathrm{L}$ & 0.709 & $\begin{array}{l}\text { An infusion of leaves } \\
\text { is used for cancer, } \\
\text { nerve system } \\
\text { disorders, heart } \\
\text { diseases, diabetes, to } \\
\text { increase appetite, and } \\
\text { anthelmintic. }\end{array}$ \\
\hline 31. & $\begin{array}{l}\text { Artemisia } \\
\text { verlotiorum } \\
\text { Lamotte. }\end{array}$ & 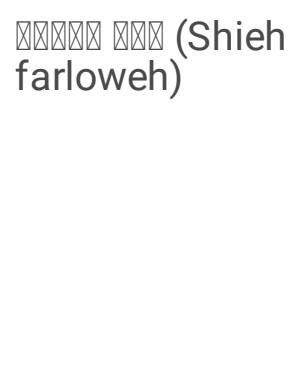 & Asteraceae & $\mathrm{L}$ & 0.036 & $\begin{array}{l}\text { A decoction of leaves } \\
\text { is used as } \\
\text { anthelmintic, and for } \\
\text { diabetes, respiratory } \\
\text { problems, diarrhea, } \\
\text { the powder of leaves } \\
\text { is used for skin } \\
\text { diseases, sores, } \\
\text { wounds. }\end{array}$ \\
\hline 32. & $\begin{array}{l}\text { Arum } \\
\text { dioscoridis Sm. }\end{array}$ & प्रा (Louf) & Araceae & $\mathrm{L}$ & 0.414 & $\begin{array}{l}\text { A cooked leaves are } \\
\text { used for digestion } \\
\text { disorders treatment, } \\
\text { asthma treatment, } \\
\text { internal bacterial } \\
\text { infection, and } \\
\text { anthelmintic. }\end{array}$ \\
\hline 33. & $\begin{array}{l}\text { Asparagus } \\
\text { officinalis } \mathrm{L} \text {. }\end{array}$ & 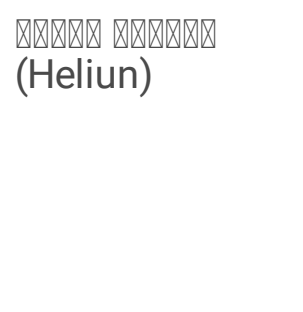 & Asparagaceae & $\begin{array}{l}\text { R, } \\
\text { Sh }\end{array}$ & 0.636 & $\begin{array}{l}\text { A cooked roots and } \\
\text { shoots are used for } \\
\text { urinary tract diseases, } \\
\text { lowering blood } \\
\text { pressure, analgesic, } \\
\text { and anti- } \\
\text { inflammatory. }\end{array}$ \\
\hline 34. & $\begin{array}{l}\text { Asphodelus } \\
\text { microcarpus } \\
\text { Salzm. et Viv. }\end{array}$ & 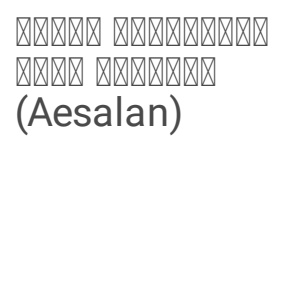 & Alliaceae & W & 0.029 & $\begin{array}{l}\text { The juice of this plant } \\
\text { has been applied } \\
\text { dermatologically to } \\
\text { treat cutaneous } \\
\text { lichen, even though } \\
\text { the plant is } \\
\text { poisonous. }\end{array}$ \\
\hline
\end{tabular}




\begin{tabular}{|c|c|c|c|c|c|c|}
\hline No. & $\begin{array}{l}\text { Name of } \\
\text { Species }\end{array}$ & $\begin{array}{l}\text { Common } \\
\text { Name (Arabic } \\
\text { Language) }\end{array}$ & Family & $\begin{array}{l}\text { Part } \\
\text { Used }\end{array}$ & MUV & Ethnobotanical Uses \\
\hline
\end{tabular}

\begin{tabular}{|c|c|c|c|c|c|c|}
\hline 35. & Avena sativa $\mathrm{L}$. & प्राप्य (Shofan) & Poaceae & $\begin{array}{l}\mathrm{Sd} \\
\mathrm{Pe}\end{array}$ & 0.72 & $\begin{array}{l}\text { The bran husk of } \\
\text { seed is a mealy } \\
\text { nutritive herb used for } \\
\text { weight reduction, and } \\
\text { constipation, the } \\
\text { whole grinded seeds } \\
\text { are used for } \\
\text { diabetes, } \\
\text { hypercholesterolemia, } \\
\text { diuretic, and } \\
\text { antispasmodic, and } \\
\text { tonic for the nervous } \\
\text { system. }\end{array}$ \\
\hline
\end{tabular}

\begin{tabular}{|c|c|c|c|c|c|c|}
\hline 36. & $\begin{array}{l}\text { Bellis sylvestris } \\
\text { Cirillo }\end{array}$ & 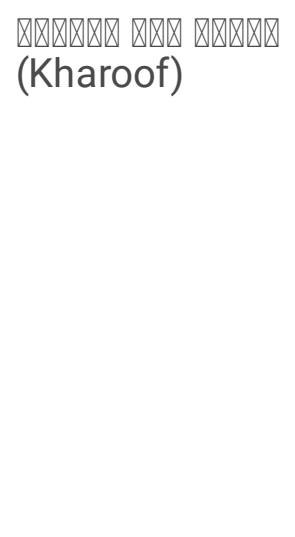 & Asteraceae & $S$ & 0.152 & $\begin{array}{l}\text { An infusion of stems } \\
\text { is used in the } \\
\text { treatment of catarrh, } \\
\text { rheumatism, arthritis, } \\
\text { liver and kidney } \\
\text { disorders, as a blood } \\
\text { purifier, A mild } \\
\text { decoction may ease } \\
\text { complaints of the } \\
\text { respiratory tract, } \\
\text { rheumatic pains and } \\
\text { painful or heavy } \\
\text { menstruation. }\end{array}$ \\
\hline
\end{tabular}

\begin{tabular}{|c|c|c|c|c|c|c|}
\hline 37. & Beta vulgaris $\mathrm{L}$. & प्रा (Solk) & Amaranthaceae & Ap & 0.723 & $\begin{array}{l}\text { An green parts of the } \\
\text { herb are eaten to treat } \\
\text { constipation, } \\
\text { diabetes, anemia and } \\
\text { general weakness, } \\
\text { and is used for } \\
\text { hypertension. }\end{array}$ \\
\hline
\end{tabular}

\begin{tabular}{|c|c|c|c|c|c|}
\hline $\begin{array}{ll}\text { 38. } & \text { Bidens pilosa } \\
\text { L. }\end{array}$ & 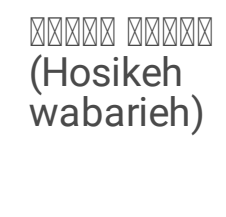 & Asteraceae & Ap & 0.105 & $\begin{array}{l}\text { A decoction is used } \\
\text { for digestive } \\
\text { disorders, fresh aerial } \\
\text { parts are used to treat } \\
\text { bites, wounds. }\end{array}$ \\
\hline
\end{tabular}

\begin{tabular}{|c|c|c|c|c|c|c|}
\hline 39. & $\begin{array}{l}\text { Borago } \\
\text { officinalis L. }\end{array}$ & 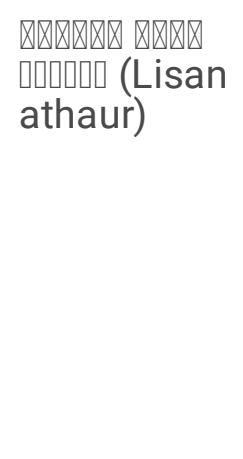 & Boraginaceae & $\begin{array}{l}L_{1} \\
\text { Sd, } F\end{array}$ & 0.701 & $\begin{array}{l}\text { An infusion of leaves } \\
\text { and seeds and } \\
\text { flowers is used for } \\
\text { treatments for } \\
\text { infections, respiratory } \\
\text { complaints, } \\
\text { depression, arthritis, } \\
\text { asthma, and the fresh } \\
\text { leaves are used as } \\
\text { mealy nutritive herb } \\
\text { and diuretic. }\end{array}$ \\
\hline
\end{tabular}




\begin{tabular}{|c|c|c|c|c|c|c|}
\hline No. & $\begin{array}{l}\text { Name of } \\
\text { Species }\end{array}$ & $\begin{array}{l}\text { Common } \\
\text { Name (Arabic } \\
\text { Language) }\end{array}$ & Family & $\begin{array}{l}\text { Part } \\
\text { Used }\end{array}$ & MUV & Ethnobotanical Uses \\
\hline 40. & $\begin{array}{l}\text { Calendula } \\
\text { arvensis } \\
\text { M.Bieb. }\end{array}$ & $\begin{array}{l}\text { (Ain El-Baquar) } \\
\text { (Ain El }\end{array}$ & Asteraceae & Ap & 0.098 & $\begin{array}{l}\text { An infusion of aerial } \\
\text { parts is used as a } \\
\text { remedy for skin } \\
\text { problems and is } \\
\text { applied externally to } \\
\text { bites and stings, } \\
\text { sprains, wounds, sore } \\
\text { eyes, varicose veins. }\end{array}$ \\
\hline 41. & $\begin{array}{l}\text { Capparis } \\
\text { spinosa L. }\end{array}$ & प्रा (Cabar) & Capparaceae & $\begin{array}{l}\text { Sh, } \\
\mathrm{R}\end{array}$ & 0.629 & $\begin{array}{l}\text { A young shoots } \\
\text { pickled either in } \\
\text { vinegar or preserved } \\
\text { in granular salt are } \\
\text { used for diseases of } \\
\text { the nervous system, } \\
\text { back pain, liver } \\
\text { diseases, the fresh } \\
\text { roots are used } \\
\text { topically for back } \\
\text { pain and } \\
\text { rheumatism. }\end{array}$ \\
\hline 42. & $\begin{array}{l}\text { Capsella bursa- } \\
\text { pastoris (L.) } \\
\text { Medik. }\end{array}$ & 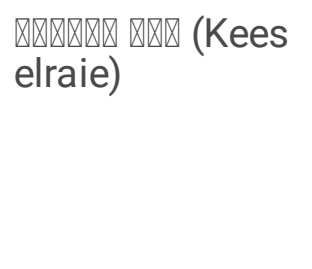 & Brassicaceae & $\mathrm{L}$ & 0.101 & $\begin{array}{l}\text { A decoction of leaves } \\
\text { is used for treat sores } \\
\text { and menstrual pain, } \\
\text { hypertension, diuretic } \\
\text { and relieve stomach } \\
\text { acid. }\end{array}$ \\
\hline 43. & $\begin{array}{l}\text { Capsicum } \\
\text { annuum L. }\end{array}$ & प्राप्रा (Flefleh) & Solanaceae & $\mathrm{F}$ & 0.694 & $\begin{array}{l}\text { The fresh fruits are } \\
\text { used for common } \\
\text { cold, and it soaked in } \\
\text { olive oil and used } \\
\text { topically for joint pain } \\
\text { and back pain. }\end{array}$ \\
\hline 44. & $\begin{array}{l}\text { Carissa edulis } \\
\text { (Forssk.) Vahl }\end{array}$ & प्राप्र (Airon) & Apocynaceae & $\mathrm{R}$ & 0.094 & $\begin{array}{l}\text { A preparation from } \\
\text { root is used topically } \\
\text { for lichen disease. }\end{array}$ \\
\hline 45. & $\begin{array}{l}\text { Carduus } \\
\text { argentatus L. }\end{array}$ & 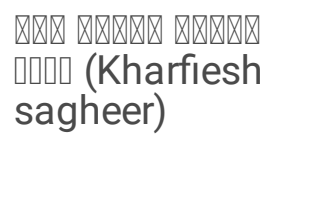 & Asteraceae & Ap & 0.836 & $\begin{array}{l}\text { A decoction of aerial } \\
\text { parts is used for liver } \\
\text { diseases and low } \\
\text { blood sugar, and } \\
\text { cases of infertility. }\end{array}$ \\
\hline
\end{tabular}




\begin{tabular}{|c|c|c|c|c|c|c|}
\hline No. & $\begin{array}{l}\text { Name of } \\
\text { Species }\end{array}$ & $\begin{array}{l}\text { Common } \\
\text { Name (Arabic } \\
\text { Language) }\end{array}$ & Family & $\begin{array}{l}\text { Part } \\
\text { Used }\end{array}$ & MUV & Ethnobotanical Uses \\
\hline 46. & $\begin{array}{l}\text { Carduus } \\
\text { pycnocephalus } \\
\text { L. }\end{array}$ & $\begin{array}{l}\text { Q } \\
\text { (Lesan el-kalb) }\end{array}$ & Asteraceae & L & 0.589 & $\begin{array}{l}\text { A decoction of leaves } \\
\text { of the plant are used } \\
\text { to treat the diseases } \\
\text { of the gallbladder } \\
\text { and liver, and } \\
\text { hepatitis, tonic, } \\
\text { diabetes and } \\
\text { atherosclerosis, } \\
\text { reduce cholesterol in } \\
\text { the blood, stimulates } \\
\text { digestion and } \\
\text { strengthens the } \\
\text { appetite, anti-worms. }\end{array}$ \\
\hline 47. & $\begin{array}{l}\text { Carex } \\
\text { stenophylla } \\
\text { Wahlenb. }\end{array}$ & पस्पा (Namees) & Cyperaceae & W & 0.08 & $\begin{array}{l}\text { A decoction of grass } \\
\text { is used as diaphoretic } \\
\text { and carminative. }\end{array}$ \\
\hline 48. & $\begin{array}{l}\text { Carthamus } \\
\text { tenuis (Boiss. \& } \\
\text { Blanche) } \\
\text { Bornm. }\end{array}$ & 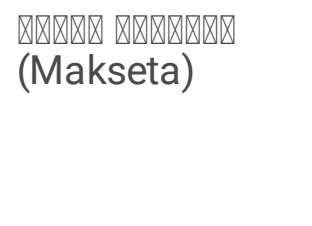 & Asteraceae & Ap & 0.68 & $\begin{array}{l}\text { The aerial parts of } \\
\text { the plant are boiled, } \\
\text { then squeezed and } \\
\text { fried in oil as a } \\
\text { nutrient. }\end{array}$ \\
\hline 49. & $\begin{array}{l}\text { Carthamus } \\
\text { tinctorius } \mathrm{L} .\end{array}$ & प्राप (Isfer) & Asteraceae & Sd & 0.243 & $\begin{array}{l}\text { A seed oil is used to } \\
\text { prevent heart disease, } \\
\text { dysmenorrhea, } \\
\text { amenorrhea, } \\
\text { postpartum } \\
\text { abdominal pain, pain } \\
\text { of joints. }\end{array}$ \\
\hline 50. & $\begin{array}{l}\text { Celosia cristata } \\
\text { L. }\end{array}$ & 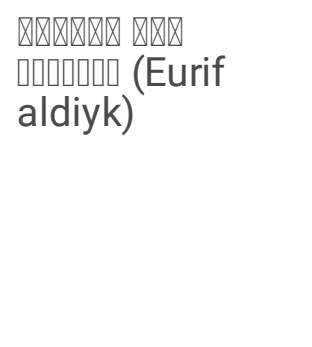 & Amaranthaceae & L, Sd & 0.265 & $\begin{array}{l}\text { The leaves decoction } \\
\text { is used as an } \\
\text { antidiarrheal, seed } \\
\text { decoction is used as } \\
\text { a laxative, in cases of } \\
\text { cough, and dysarthria } \\
\text { urination, and for } \\
\text { pain. }\end{array}$ \\
\hline 51. & $\begin{array}{l}\text { Centaurea } \\
\text { calcitrapa L. }\end{array}$ & 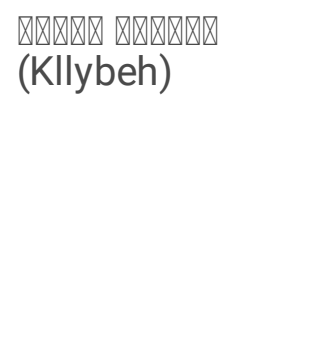 & Asteraceae & L & 0.625 & $\begin{array}{l}\text { The fresh leaves are } \\
\text { used as appetite } \\
\text { enhancer, and for } \\
\text { diarrhea, the cooked } \\
\text { leaves are edible as } \\
\text { special traditional } \\
\text { Syrian recipe known } \\
\text { as Syrian saleeg. }\end{array}$ \\
\hline
\end{tabular}




\begin{tabular}{|c|c|c|c|c|c|c|}
\hline No. & $\begin{array}{l}\text { Name of } \\
\text { Species }\end{array}$ & $\begin{array}{l}\text { Common } \\
\text { Name (Arabic } \\
\text { Language) }\end{array}$ & Family & $\begin{array}{l}\text { Part } \\
\text { Used }\end{array}$ & MUV & Ethnobotanical Uses \\
\hline 52. & $\begin{array}{l}\text { Centaurea } \\
\text { cyanus L. }\end{array}$ & $\begin{array}{l}\text { (Nada amber) } \\
\text { (Nada amb }\end{array}$ & Asteraceae & $\mathrm{FI}$ & 0.083 & $\begin{array}{l}\text { An infusion of } \\
\text { flowers for treating } \\
\text { fever, constipation } \\
\text { and urinary tract } \\
\text { infections, Cornflower } \\
\text { floral water is used } \\
\text { topically as antiseptic } \\
\text { agent. }\end{array}$ \\
\hline 53. & $\begin{array}{l}\text { Centaurium } \\
\text { erythraea Rafn }\end{array}$ & 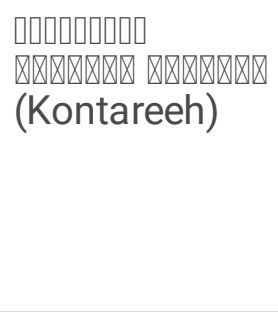 & Gentianaceae & Ap & 0.254 & $\begin{array}{l}\text { An infusion of aerial } \\
\text { parts is used for } \\
\text { diabetes, and for } \\
\text { digestive system } \\
\text { disorders, and topical } \\
\text { it is used to treat } \\
\text { sores. }\end{array}$ \\
\hline 54. & $\begin{array}{l}\text { Cephalanthera } \\
\text { kurdica Bornm. } \\
\text { ex Kraenzl. }\end{array}$ & प्राप्या (Orkid) & Orchidaceae & $\mathrm{T}$ & 0.069 & $\begin{array}{l}\text { Orchid powder } \\
\text { (Salep) is extracted } \\
\text { from orchid tubers, } \\
\text { and it is the main } \\
\text { ingredient of the } \\
\text { winter Syrian } \\
\text { traditional drink with } \\
\text { milk, which is used } \\
\text { for reducing } \\
\text { heartburn, } \\
\text { indigestion. }\end{array}$ \\
\hline 55. & $\begin{array}{l}\text { Cephalaria } \\
\text { joppensis } \\
\text { (Rchb.) Coult. } \\
\text { ex DC. }\end{array}$ & 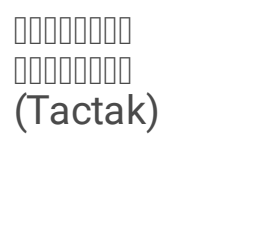 & Dipsacaceae & L & 0.021 & $\begin{array}{l}\text { An infusion of leaves } \\
\text { is used to treat } \\
\text { diabetes, digestive } \\
\text { disorders, and as a } \\
\text { laxative and diuretic. }\end{array}$ \\
\hline 56. & $\begin{array}{l}\text { Ceratonia } \\
\text { siliqua L. }\end{array}$ & 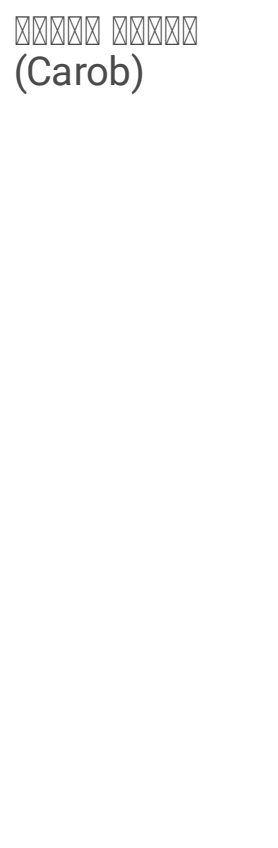 & Fabaceae & $\mathrm{F}$ & 0.592 & $\begin{array}{l}\text { The carob fruits are } \\
\text { soaked in water ( } 1 \\
\text { kilogram to two liters } \\
\text { of water) for three } \\
\text { hours, then placed on } \\
\text { a strong fire for about } \\
\text { an hour, after which it } \\
\text { cools, and we filter it } \\
\text { with a clean piece of } \\
\text { gauze, then add two } \\
\text { cups of sugar for } \\
\text { sweetening and } \\
\text { preservation, and add } \\
\text { to it Damask rose } \\
\text { water, it is used for } \\
\text { the treatment of } \\
\text { heartburn, and reduce } \\
\text { the frequency of } \\
\text { vomiting, } \\
\text { constipation, and } \\
\text { Increased breast milk. }\end{array}$ \\
\hline
\end{tabular}




\begin{tabular}{|c|c|c|c|c|c|c|}
\hline No. & $\begin{array}{l}\text { Name of } \\
\text { Species }\end{array}$ & $\begin{array}{l}\text { Common } \\
\text { Name (Arabic } \\
\text { Language) }\end{array}$ & Family & $\begin{array}{l}\text { Part } \\
\text { Used }\end{array}$ & MUV & Ethnobotanical Uses \\
\hline 57. & $\begin{array}{l}\text { Cercis } \\
\text { siliquastrum L. }\end{array}$ & 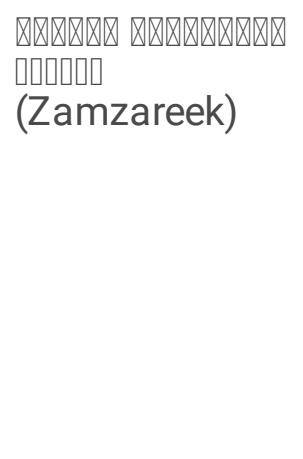 & Fabaceae & $\begin{array}{l}\mathrm{Fl}, \\
\mathrm{Bk}\end{array}$ & 0.029 & $\begin{array}{l}\text { The honey of flower's } \\
\text { nectar is used in the } \\
\text { treatment of some } \\
\text { diseases, such as } \\
\text { anemia, general } \\
\text { weakness, fatigue, } \\
\text { stress, and the } \\
\text { infusion of flowers } \\
\text { and bark is used as a } \\
\text { tonic, and for } \\
\text { digestive disorders. }\end{array}$ \\
\hline 58. & $\begin{array}{l}\text { Chrozophora } \\
\text { tinctoria (L.) } \\
\text { A.Juss. }\end{array}$ & 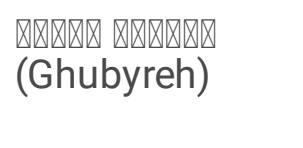 & Euphorbiaceae & $\mathrm{L}$ & 0.032 & $\begin{array}{l}\text { The fresh leaves are } \\
\text { used as diuretic, and } \\
\text { for kidney stones. }\end{array}$ \\
\hline 59. & $\begin{array}{l}\text { Cichorium } \\
\text { intybus L. }\end{array}$ & $\begin{array}{l}\text { प्राप्रा } \\
\text { (Hinduba) }\end{array}$ & Asteraceae & $L, R$ & 0.85 & $\begin{array}{l}\text { An infusion of leaves } \\
\text { is used for improving } \\
\text { immunity, protecting } \\
\text { the heart, and for } \\
\text { cancer, and eye } \\
\text { inflammation, the } \\
\text { fresh leaves are used } \\
\text { as diuretic, laxative, } \\
\text { and slimming, the } \\
\text { roasted of roots for } \\
\text { liver diseases, the } \\
\text { leaves are edible as } \\
\text { special salad. }\end{array}$ \\
\hline 60. & $\begin{array}{l}\text { Cirsium amani } \\
\text { Post. }\end{array}$ & 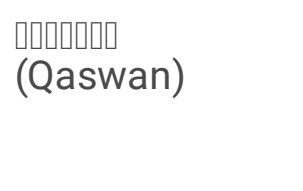 & Asteraceae & $\mathrm{L}$ & 0.01 & $\begin{array}{l}\text { A decoction of leaves } \\
\text { is used as } \\
\text { expectorant and } \\
\text { diuretic. }\end{array}$ \\
\hline 61. & $\begin{array}{l}\text { Cistus creticus } \\
\text { L. }\end{array}$ & 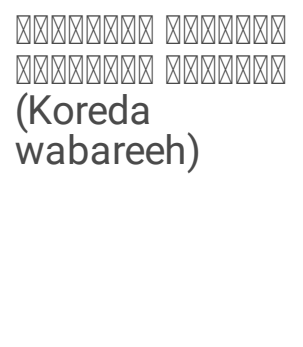 & Cistaceae & $L, G$ & 0.003 & $\begin{array}{l}\text { An infusion of leaves } \\
\text { is used as an } \\
\text { expectorant, and as } \\
\text { an emmenagogue, } \\
\text { the gum of its tree is } \\
\text { solved with olive oil } \\
\text { and topical is used } \\
\text { for bronchitis. }\end{array}$ \\
\hline 62. & $\begin{array}{l}\text { Cistus } \\
\text { salviifolius L. }\end{array}$ & 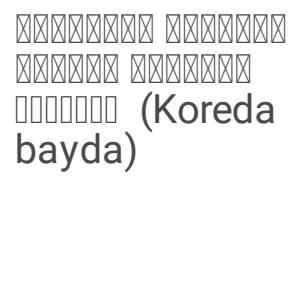 & Cistaceae & Ap & 0.007 & $\begin{array}{l}\text { A decoction of aerial } \\
\text { parts is used as anti- } \\
\text { diarrheal and } \\
\text { digestive teas, and } \\
\text { for diabetes and } \\
\text { gastrointestinal } \\
\text { ulcers. }\end{array}$ \\
\hline
\end{tabular}




\begin{tabular}{|c|c|c|c|c|c|c|}
\hline No. & $\begin{array}{l}\text { Name of } \\
\text { Species }\end{array}$ & $\begin{array}{l}\text { Common } \\
\text { Name (Arabic } \\
\text { Language) }\end{array}$ & Family & $\begin{array}{l}\text { Part } \\
\text { Used }\end{array}$ & MUV & Ethnobotanical Uses \\
\hline 63. & $\begin{array}{l}\text { Citrus limon } \\
\text { (L.) Osbeck }\end{array}$ & $\begin{array}{l}\text { (Limun hamd) } \\
\text { (Limu姆 }\end{array}$ & Rutaceae & $\mathrm{F}$ & 0.861 & $\begin{array}{l}\text { A fresh juice of fruits } \\
\text { is used for flu, } \\
\text { common cold, the } \\
\text { dried peels of fruits } \\
\text { are used for diseases } \\
\text { of stomach, intestine } \\
\text { and urinary tract. }\end{array}$ \\
\hline 64. & $\begin{array}{l}\text { Citrus } x \\
\text { aurantium L. }\end{array}$ & $\begin{array}{l}\text { प्राप्राप } \\
\text { (Bortokal) }\end{array}$ & Rutaceae & $\mathrm{F}$ & 0.88 & $\begin{array}{l}\text { A fresh juice of fruits } \\
\text { is used for refreshing } \\
\text { and anti-cough and } \\
\text { flu, and aromatic oil } \\
\text { of peels is used } \\
\text { inhalation as a } \\
\text { decongestant. }\end{array}$ \\
\hline 65. & $\begin{array}{l}\text { Clematis } \\
\text { flammula L. }\end{array}$ & 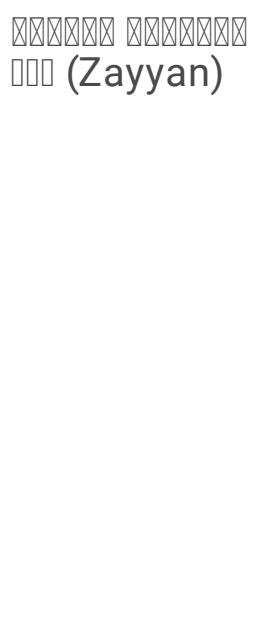 & Ranunculaceae & $\mathrm{L}, \mathrm{FI}$ & 0.04 & $\begin{array}{l}\text { The ancient use of } \\
\text { the leaves and } \\
\text { flowers is for gout } \\
\text { and arthritis both } \\
\text { orally as an infusion, } \\
\text { and topically with } \\
\text { olive oil, also the } \\
\text { dried grinded of } \\
\text { leaves and flowers is } \\
\text { used for vitiligo } \\
\text { topically with a } \\
\text { vinegar. Some } \\
\text { caution is advised } \\
\text { due to reports of } \\
\text { toxicity. }\end{array}$ \\
\hline 66. & $\begin{array}{l}\text { Cochlearia } \\
\text { officinalis } \mathrm{L} .\end{array}$ & $\begin{array}{l}\text { (Hasheshate } \\
\text { elmalaek) }\end{array}$ & Brassicaceae & $\begin{array}{l}\text { W, } \\
A p\end{array}$ & 0.232 & $\begin{array}{l}\text { A fresh herb is used } \\
\text { as tonic and } \\
\text { nutritious agent, an } \\
\text { infusion of aerial } \\
\text { parts is used } \\
\text { internally for } \\
\text { rheumatism and as a } \\
\text { diuretic, while the } \\
\text { external applications } \\
\text { a decoction is used } \\
\text { as a mouthwash for } \\
\text { diseases of the } \\
\text { mouth, throat and } \\
\text { larynx. }\end{array}$ \\
\hline 67. & $\begin{array}{l}\text { Convolvulus } \\
\text { betonicifolius } \\
\text { Mill. }\end{array}$ & 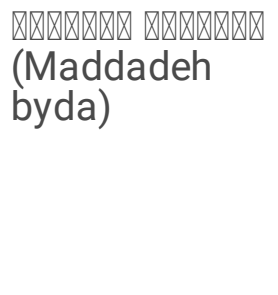 & Convolvulaceae & $A p$ & 0.101 & $\begin{array}{l}\text { A decoction of aerial } \\
\text { parts is used } \\
\text { internally for fever, } \\
\text { loss of memory, } \\
\text { insomnia, and as } \\
\text { antispasmodic, } \\
\text { laxative, diuretic. }\end{array}$ \\
\hline
\end{tabular}




\begin{tabular}{|c|c|c|c|c|c|c|}
\hline No. & $\begin{array}{l}\text { Name of } \\
\text { Species }\end{array}$ & $\begin{array}{l}\text { Common } \\
\text { Name (Arabic } \\
\text { Language) }\end{array}$ & Family & $\begin{array}{l}\text { Part } \\
\text { Used }\end{array}$ & MUV & Ethnobotanical Uses \\
\hline 68. & $\begin{array}{l}\text { Convolvulus } \\
\text { cantabrica L. }\end{array}$ & $\begin{array}{l}\text { (Maddadeh) } \\
\text { (Mand }\end{array}$ & Convolvulaceae & L & 0.094 & $\begin{array}{l}\text { An infusion of leaves } \\
\text { is used as diuretic, } \\
\text { and for kidney stone. }\end{array}$ \\
\hline 69. & $\begin{array}{l}\text { Convolvulus } \\
\text { sepium L. }\end{array}$ & 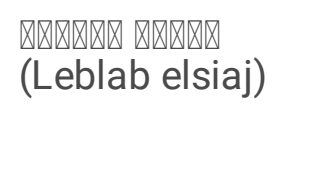 & Convolvulaceae & $\mathrm{R}, \mathrm{FI}$ & 0.101 & $\begin{array}{l}\text { A decoction of roots } \\
\text { and flowering herbs } \\
\text { are used to treat } \\
\text { constipation. }\end{array}$ \\
\hline 70. & $\begin{array}{l}\text { Coriandrum } \\
\text { sativum } \mathrm{L} .\end{array}$ & 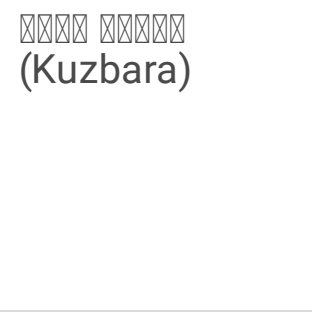 & Apiaceae & Sd & 0.68 & $\begin{array}{l}\text { A decoction of seeds } \\
\text { is used for intestinal } \\
\text { inflammation, weight } \\
\text { loss and intestinal } \\
\text { gas, treating } \\
\text { narrowed arteries, } \\
\text { diabetes. }\end{array}$ \\
\hline 71. & $\begin{array}{l}\text { Cornus } \\
\text { sanguinea } \\
\text { subsp. } \\
\text { australis } \\
\text { (C.A.Mey.) Jáv. }\end{array}$ & 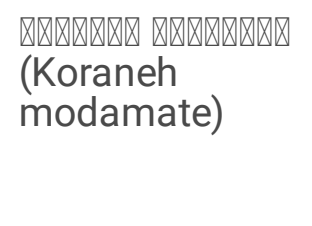 & Cornaceae & $\mathrm{F}, \mathrm{FI}$ & 0.076 & $\begin{array}{l}\text { An infusion of fruit } \\
\text { and flowers is used } \\
\text { for rheumatism and } \\
\text { menstrual bleeding } \\
\text { and as tonic. }\end{array}$ \\
\hline 72. & $\begin{array}{l}\text { Crataegus } \\
\text { monogyna } \\
\text { Jacq. }\end{array}$ & 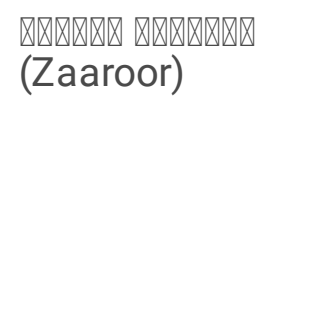 & Rosaceae & $\mathrm{F}$ & 0.603 & $\begin{array}{l}\text { A decoction of fruits } \\
\text { is used for } \\
\text { cardiovascular } \\
\text { diseases, } \\
\text { hypertension, sexual } \\
\text { weakness, cancer } \\
\text { and diabetes. }\end{array}$ \\
\hline 73. & $\begin{array}{l}\text { Crepis } \\
\text { reuteriana } \\
\text { Boiss. / Crepis } \\
\text { syriaca } \\
\text { (Bornm.) Babc. } \\
\text { \& Navashin }\end{array}$ & 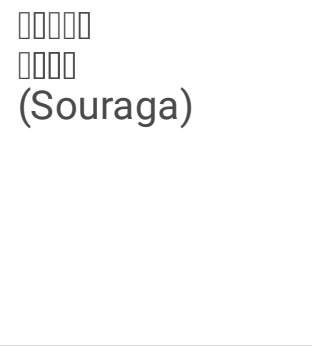 & Asteraceae & W & 0.018 & $\begin{array}{l}\text { The fresh young } \\
\text { leaves are resemble a } \\
\text { dandelion and they } \\
\text { are confused and this } \\
\text { wild edible plant is } \\
\text { used as salad for } \\
\text { relieve joint diseases } \\
\text { pain, appetizer. }\end{array}$ \\
\hline 74. & $\begin{array}{l}\text { Cupressus } \\
\text { sempervirens } \\
\text { L. }\end{array}$ & $\begin{array}{l}\text { W } \\
\text { (Saru akhdar) }\end{array}$ & Cuppressaceae & L & 0.236 & $\begin{array}{l}\text { A decoction of leaves } \\
\text { and cones is used as } \\
\text { an antispasmodic } \\
\text { and for treating colds, } \\
\text { flu and sore throats, } \\
\text { Externally cypress oil } \\
\text { is used for varicose } \\
\text { veins and } \\
\text { hemorrhoids and as } \\
\text { antirheumatic. }\end{array}$ \\
\hline
\end{tabular}




\begin{tabular}{|c|c|c|c|c|c|c|}
\hline No. & $\begin{array}{l}\text { Name of } \\
\text { Species }\end{array}$ & $\begin{array}{l}\text { Common } \\
\text { Name (Arabic } \\
\text { Language) }\end{array}$ & Family & $\begin{array}{l}\text { Part } \\
\text { Used }\end{array}$ & MUV & Ethnobotanical Uses \\
\hline 75. & $\begin{array}{l}\text { Cucurbita Pepo } \\
\text { L. }\end{array}$ & 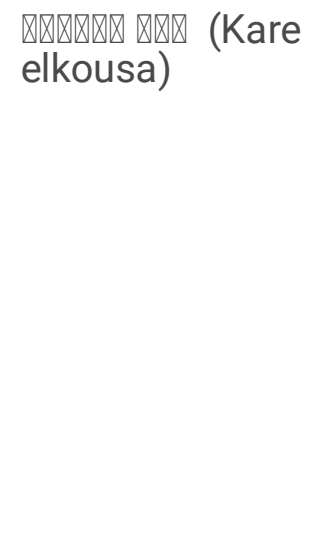 & Cucurbitaceae & Sd & 0.589 & $\begin{array}{l}\text { The dried and roasted } \\
\text { seeds and the oil are } \\
\text { used to get rid of } \\
\text { intestinal worms, } \\
\text { especially } \\
\text { tapeworms. also } \\
\text { used to relieve the } \\
\text { symptoms of benign } \\
\text { prostatic hyperplasia } \\
\text { in the elderly. and for } \\
\text { vomiting in pregnant } \\
\text { women. also for } \\
\text { seasickness. }\end{array}$ \\
\hline 76. & $\begin{array}{l}\text { Cyclamen } \\
\text { persicum Mill. }\end{array}$ & 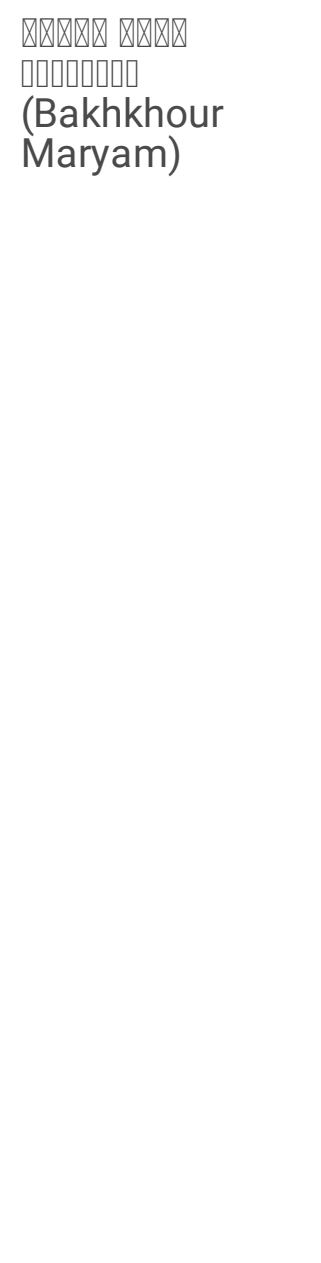 & Primulaceae & $\mathrm{L}, \mathrm{T}$ & 0.069 & $\begin{array}{l}\text { Its leaves are } \\
\text { wrapped with rice like } \\
\text { grape leaves which } \\
\text { is called (ybraq or } \\
\text { warak enab) and } \\
\text { cooked. and it is used } \\
\text { in cases of } \\
\text { impotence by eating } \\
\text { it, the herb boiled is } \\
\text { used to expel } \\
\text { abdominal worms, } \\
\text { constipation, } \\
\text { rheumatism and lack } \\
\text { of sensation in the } \\
\text { limbs in patients with } \\
\text { diabetes and peptic } \\
\text { ulcers. Externally, the } \\
\text { tubers are used to } \\
\text { treat boils, sores and } \\
\text { festering wounds. } \\
\text { The tuber is grinded } \\
\text { and placed in a piece } \\
\text { of cloth then placed } \\
\text { on it, but it is toxic. } \\
\text { must be used } \\
\text { carefully. Skin burns } \\
\text { are also treated by } \\
\text { drying leaves, } \\
\text { grinding them and } \\
\text { spraying their powder } \\
\text { on the burns. }\end{array}$ \\
\hline
\end{tabular}




\begin{tabular}{|c|c|c|c|c|c|c|}
\hline No. & $\begin{array}{l}\text { Name of } \\
\text { Species }\end{array}$ & $\begin{array}{l}\text { Common } \\
\text { Name (Arabic } \\
\text { Language) }\end{array}$ & Family & $\begin{array}{l}\text { Part } \\
\text { Used }\end{array}$ & MUV & Ethnobotanical Uses \\
\hline 77. & $\begin{array}{l}\text { Cynodon } \\
\text { dactylon (L.) } \\
\text { Pers. }\end{array}$ & 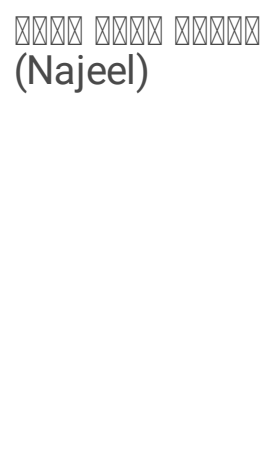 & Poaceae & $\mathrm{R}$ & 0.174 & $\begin{array}{l}\text { A decoction of roots } \\
\text { is used internally as } \\
\text { bile tonic, fever } \\
\text { repellent, } \\
\text { anthelmintic, to get } \\
\text { rid of toxins and } \\
\text { arthritis, diuretic, } \\
\text { helps to slim, and } \\
\text { externally used for } \\
\text { urticaria and skin } \\
\text { eczema. }\end{array}$ \\
\hline 78. & $\begin{array}{l}\text { Cydonia } \\
\text { oblonga Mill. }\end{array}$ & $\begin{array}{l}\text { (Sapharjal) } \\
\text { (Saphat }\end{array}$ & Rosaceae & $\mathrm{F}$ & 0.53 & $\begin{array}{l}\text { The fruits juice is } \\
\text { used for gastric } \\
\text { acidity, and as } \\
\text { astringent and } \\
\text { intestinal } \\
\text { disinfectant, it } \\
\text { contributes to the } \\
\text { treatment of peptic } \\
\text { ulcers and intestinal } \\
\text { upset, and in the } \\
\text { treatment of diarrhea, } \\
\text { intestinal infections } \\
\text { and constipation, and } \\
\text { quince is considered } \\
\text { a diuretic and thus } \\
\text { helps in cleaning the } \\
\text { body from toxins, and } \\
\text { commonly the fruits } \\
\text { jam is prepared to } \\
\text { use for some } \\
\text { medicinal and } \\
\text { nutritional uses } \\
\text { mentioned above. }\end{array}$ \\
\hline 79. & $\begin{array}{l}\text { Cynoglossum } \\
\text { creticum Mill. }\end{array}$ & 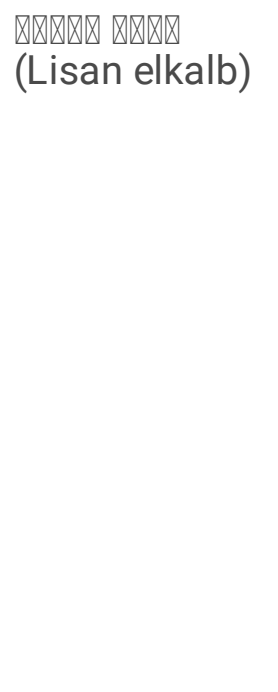 & Boraginaceae & $L, R$ & 0.069 & $\begin{array}{l}\text { Fresh or dried young } \\
\text { leaves are used } \\
\text { internally in the form } \\
\text { of infusions or boiled } \\
\text { as antipyretic and } \\
\text { diuretic, useful for } \\
\text { lung diseases, } \\
\text { antispasmodic, and } \\
\text { the decoction of roots } \\
\text { is used as analgesic } \\
\text { for cough, and the } \\
\text { fresh leaves are used } \\
\text { as salad, and } \\
\text { externally the oil of } \\
\text { herb is used for sores, } \\
\text { and for treating skin } \\
\text { infections. }\end{array}$ \\
\hline
\end{tabular}




\begin{tabular}{|c|c|c|c|c|c|c|}
\hline No. & $\begin{array}{l}\text { Name of } \\
\text { Species }\end{array}$ & $\begin{array}{l}\text { Common } \\
\text { Name (Arabic } \\
\text { Language) }\end{array}$ & Family & $\begin{array}{l}\text { Part } \\
\text { Used }\end{array}$ & MUV & Ethnobotanical Uses \\
\hline 80. & $\begin{array}{l}\text { Cyperus } \\
\text { rotundus L. }\end{array}$ & प्राप्र (Sued) & Cyperaceae & $\mathrm{T}, \mathrm{Sd}$ & 0.105 & $\begin{array}{l}\text { A decoction of tuber } \\
\text { part is used for } \\
\text { digestion, bedwetting, } \\
\text { diarrhea, diabetes, } \\
\text { inflammation, and } \\
\text { gastrointestinal } \\
\text { disorder, the oil of } \\
\text { seeds is used } \\
\text { topically for } \\
\text { permanent hair } \\
\text { remove and for } \\
\text { burns. }\end{array}$ \\
\hline 81. & $\begin{array}{l}\text { Dactylis } \\
\text { glomerata L. }\end{array}$ & 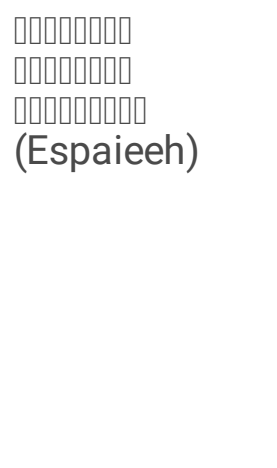 & Poaceae & $\mathrm{R}$ & 0.007 & $\begin{array}{l}\text { Gargling with boiled } \\
\text { roots for dental pain, } \\
\text { and applying the } \\
\text { decoction of boiled } \\
\text { roots to the skin to } \\
\text { treat a rash, and } \\
\text { internally, drinking } \\
\text { boiled roots as a } \\
\text { diuretic, and for } \\
\text { cystitis and } \\
\text { rheumatism. }\end{array}$ \\
\hline 82. & $\begin{array}{l}\text { Datura } \\
\text { stramonium L. }\end{array}$ & प्रापा (Datura) & Solanaceae & $\mathrm{R}$ & 0.014 & $\begin{array}{l}\text { Although it is a toxic } \\
\text { plant, a decoction of } \\
\text { roots is used for } \\
\text { some skin diseases. }\end{array}$ \\
\hline 83. & $\begin{array}{l}\text { Daucus carota } \\
\text { L. }\end{array}$ & 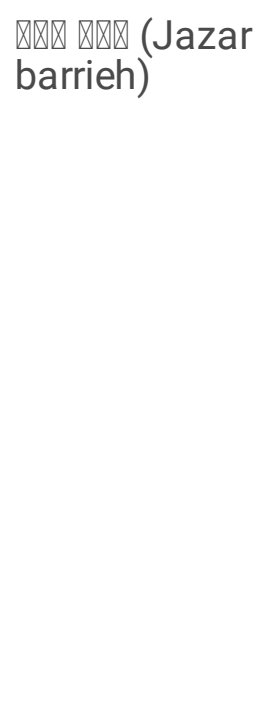 & Apiaceae & $\begin{array}{l}\mathrm{R}, \mathrm{L}, \\
\mathrm{Sd}\end{array}$ & 0.68 & $\begin{array}{l}\text { The juice of roots is } \\
\text { used for intestinal } \\
\text { infections, and } \\
\text { stomach ulcers, and } \\
\text { used as diuretic for } \\
\text { kidney patients, the } \\
\text { leaves decoction is } \\
\text { used as antiseptic for } \\
\text { skin, the seeds } \\
\text { decoction is used as } \\
\text { diuretic for those with } \\
\text { kidney problems, an } \\
\text { infusion of the roots, } \\
\text { leaves and seeds is } \\
\text { used for acne and } \\
\text { skin infections, and } \\
\text { for eczema. }\end{array}$ \\
\hline 84. & $\begin{array}{l}\text { Dianthus } \\
\text { strictus Banks } \\
\text { ex Sol. }\end{array}$ & $\begin{array}{l}\text { प } \\
\text { (Koronfel } \\
\text { barrieh) }\end{array}$ & Caryophyllaceae & $\mathrm{F}$ & 0.123 & $\begin{array}{l}\text { A decoction of fruits } \\
\text { is used for toothache } \\
\text { topically, and } \\
\text { sometimes this } \\
\text { decoction is used } \\
\text { internally as liver } \\
\text { tonic and laxative. }\end{array}$ \\
\hline
\end{tabular}




\begin{tabular}{|c|c|c|c|c|c|c|}
\hline No. & $\begin{array}{l}\text { Name of } \\
\text { Species }\end{array}$ & $\begin{array}{l}\text { Common } \\
\text { Name (Arabic } \\
\text { Language) }\end{array}$ & Family & $\begin{array}{l}\text { Part } \\
\text { Used }\end{array}$ & MUV & Ethnobotanical Uses \\
\hline 85. & $\begin{array}{l}\text { Dianthus } \\
\text { caryophyllus L. }\end{array}$ & 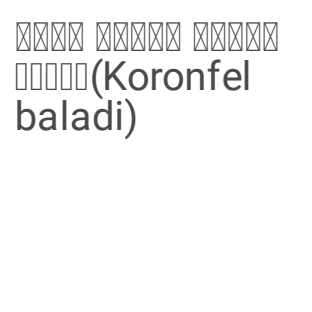 & Caryophyllaceae & $\mathrm{Bu}$ & 0.047 & $\begin{array}{l}\text { A decoction of buds } \\
\text { is used for treatment } \\
\text { of gum infections, } \\
\text { gastrointestinal } \\
\text { disorder, wounds, } \\
\text { throat, and used as } \\
\text { vermifuge. }\end{array}$ \\
\hline 86. & $\begin{array}{l}\text { Ecballium } \\
\text { elaterium (L.) } \\
\text { A. Rich. }\end{array}$ & 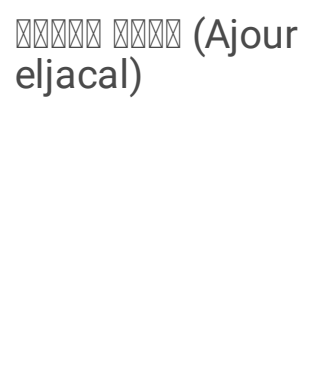 & Cucurbitaceae & $\mathrm{F}$ & 0.516 & $\begin{array}{l}\text { A fresh juice of fruits } \\
\text { is used for liver } \\
\text { diseases, jaundice } \\
\text { and sinusitis by nasal } \\
\text { administration (just } \\
\text { one drop of juice is } \\
\text { inhaled in each } \\
\text { nostril), and topical it } \\
\text { is used for eczema. }\end{array}$ \\
\hline 87. & $\begin{array}{l}\text { Echinops } \\
\text { viscosus Rchb. }\end{array}$ & 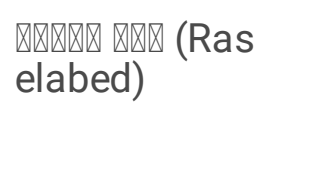 & Asteraceae & $\begin{array}{l}\text { S, R, } \\
L\end{array}$ & 0.05 & $\begin{array}{l}\text { A decoction of stem } \\
\text { and root and leaf is } \\
\text { used for renal } \\
\text { disorders. }\end{array}$ \\
\hline 88. & $\begin{array}{l}\text { Echium } \\
\text { glomeratum } \\
\text { Poir. }\end{array}$ & 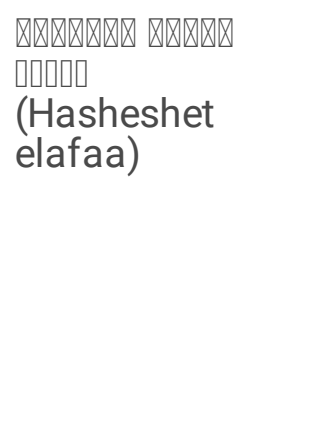 & Boraginaceae & Ap & 0.032 & $\begin{array}{l}\text { A decoction of aerial } \\
\text { parts is used as folk } \\
\text { remedy internally for } \\
\text { dry mouth and } \\
\text { belching, and used } \\
\text { for rheumatic, and } \\
\text { treatment of diabetes, } \\
\text { and used as diuretic, } \\
\text { and topically is used } \\
\text { for wound healing. }\end{array}$ \\
\hline 89. & $\begin{array}{l}\text { Elymus repens } \\
\text { L. Gould = } \\
\text { Agropyron } \\
\text { repens }(\mathrm{L} .) \\
\text { P.Beauv. }\end{array}$ & प्रा (Najeel) & Poaceae & $\mathrm{R}$ & 0.148 & $\begin{array}{l}\text { A decoction of roots } \\
\text { is used as laxative, } \\
\text { diuretic, diaphoretic } \\
\text { in cases of fever, and } \\
\text { for cystitis. }\end{array}$ \\
\hline 90. & $\begin{array}{l}\text { Ephedra } \\
\text { campylopoda } \\
\text { C.A.Mey. }\end{array}$ & 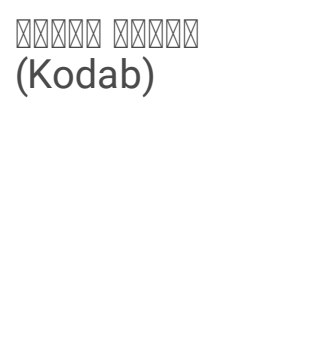 & Ephedraceae & W & 0.098 & $\begin{array}{l}\text { A decoction of whole } \\
\text { herb is used for } \\
\text { reducing arterial } \\
\text { blood pressure and } \\
\text { used for respiratory } \\
\text { diseases such as } \\
\text { asthma and chest } \\
\text { infections. }\end{array}$ \\
\hline
\end{tabular}




\begin{tabular}{|c|c|c|c|c|c|c|}
\hline No. & $\begin{array}{l}\text { Name of } \\
\text { Species }\end{array}$ & $\begin{array}{l}\text { Common } \\
\text { Name (Arabic } \\
\text { Language) }\end{array}$ & Family & $\begin{array}{l}\text { Part } \\
\text { Used }\end{array}$ & MUV & Ethnobotanical Uses \\
\hline 91. & $\begin{array}{l}\text { Epipactis } \\
\text { latifolia (L.) All. }\end{array}$ & 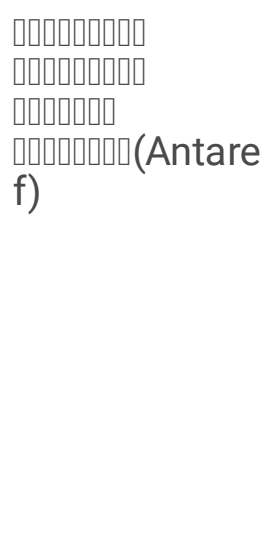 & Orchidaceae & $\begin{array}{l}\mathrm{T}, \\
\mathrm{Rm}, \\
\mathrm{L}\end{array}$ & 0.061 & $\begin{array}{l}\text { A decoction of plant } \\
\text { tubers used to treat } \\
\text { gouts, rheumatism. } \\
\text { The rhizomes powder } \\
\text { are used to treat } \\
\text { nervous disorders, } \\
\text { and aphrodisiac. } \\
\text { Infusion of leaves is } \\
\text { given in fever, and it } \\
\text { is used as an enema } \\
\text { in the case of colitis } \\
\text { and intestinal colic } \\
\text { and hemorrhoids. }\end{array}$ \\
\hline 92. & $\begin{array}{l}\text { Equisetum } \\
\text { arvense L. }\end{array}$ & $\begin{array}{l}\text { (Zanab elkhyl) } \\
\text { (Zanab }\end{array}$ & Equisetaceae & L, Sh & 0.636 & $\begin{array}{l}\text { An infusion of leaves } \\
\text { and shoots is used } \\
\text { for kidney stones and } \\
\text { has diuretic effect, for } \\
\text { gout. }\end{array}$ \\
\hline 93. & $\begin{array}{l}\text { Eremopyrum } \\
\text { orientale (L.) } \\
\text { Jaub. \& Spach. }\end{array}$ & 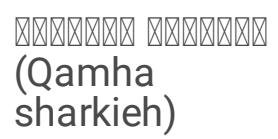 & Poaceae & $\mathrm{R}$ & 0.083 & $\begin{array}{l}\text { A decoction of roots } \\
\text { is used to clean } \\
\text { wounds. }\end{array}$ \\
\hline 94. & $\begin{array}{l}\text { Eremostachys } \\
\text { laciniata L. } \\
\text { Bunge }\end{array}$ & $\begin{array}{l}\text { (Hoznobul) } \\
\text { (Houl }\end{array}$ & Lamiaceae & $\mathrm{R}, \mathrm{FI}$ & 0.236 & $\begin{array}{l}\text { A decoction of root } \\
\text { and flower is used for } \\
\text { allergy, headache and } \\
\text { liver diseases, } \\
\text { sedative. }\end{array}$ \\
\hline 95. & $\begin{array}{l}\text { Erica } \\
\text { Manipuliflora } \\
\text { Salisb. }\end{array}$ & 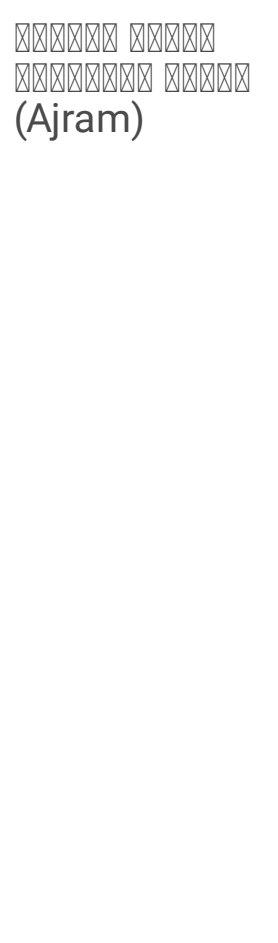 & Ericaceae & $\mathrm{FI}$ & 0.592 & $\begin{array}{l}\text { A decoction of } \\
\text { flowers is used as } \\
\text { diuretic, sedative, and } \\
\text { for treating gout and } \\
\text { urinary tract } \\
\text { infection. The heather } \\
\text { honey is commonly } \\
\text { used as tonic, anti- } \\
\text { asthma, expectorant. } \\
\text { anti-rheumatism, } \\
\text { arthritis, laxative, } \\
\text { dysmenorrhea, } \\
\text { disinfectant for the } \\
\text { respiratory tract, and } \\
\text { useful in acute } \\
\text { nephritis, bladder and } \\
\text { urinary tract } \\
\text { infections, prostate } \\
\text { pain and } \\
\text { enlargement, relieving } \\
\text { nerve pain, treating } \\
\text { insomnia and } \\
\text { depression. }\end{array}$ \\
\hline
\end{tabular}




\begin{tabular}{|c|c|c|c|c|c|c|}
\hline No. & $\begin{array}{l}\text { Name of } \\
\text { Species }\end{array}$ & $\begin{array}{l}\text { Common } \\
\text { Name (Arabic } \\
\text { Language) }\end{array}$ & Family & $\begin{array}{l}\text { Part } \\
\text { Used }\end{array}$ & MUV & Ethnobotanical Uses \\
\hline 96. & $\begin{array}{l}\text { Eriobotrya } \\
\text { japonica } \\
\text { (Thunb.) Lindl. }\end{array}$ & 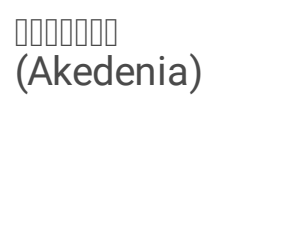 & Rosaceae & L & 0.534 & $\begin{array}{l}\text { An infusion of leaves } \\
\text { is used as sedative, } \\
\text { and for diabetes, liver } \\
\text { tonic, respiratory } \\
\text { diseases. }\end{array}$ \\
\hline 97. & $\begin{array}{l}\text { Eruca sativa } \\
\text { Miller. }\end{array}$ & प्राप्र (Jarjeer) & Brassicaceae & $\mathrm{L}, \mathrm{Sd}$ & 0.85 & $\begin{array}{l}\text { A fresh leaves are } \\
\text { used for sexual } \\
\text { weakness and blood } \\
\text { purification, diabetes, } \\
\text { anti-toxicant, oil from } \\
\text { seeds is used for hair } \\
\text { tonic, burns, skin } \\
\text { lesions, the leaves are } \\
\text { edible as special } \\
\text { salad. }\end{array}$ \\
\hline 98. & $\begin{array}{l}\text { Eryngium } \\
\text { creticum Lam. }\end{array}$ & 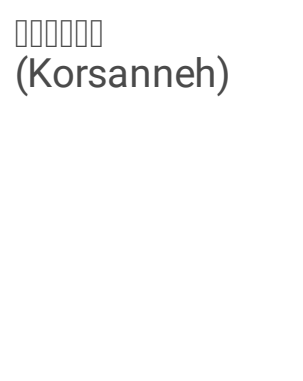 & Apiaceae & $R, L$ & 0.781 & $\begin{array}{l}\text { A decoction of roots } \\
\text { and leaves is used for } \\
\text { liver diseases, } \\
\text { poisonous, insect } \\
\text { bites, anemia and } \\
\text { infertility problems, } \\
\text { the whole plant is } \\
\text { edible as special } \\
\text { salad. }\end{array}$ \\
\hline 99. & $\begin{array}{l}\text { Eucalyptus } \\
\text { globulus Labill. }\end{array}$ & 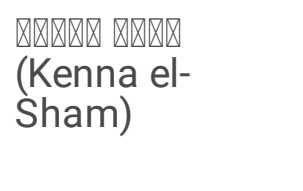 & Myrtaceae & $\mathrm{L}$ & 0.861 & $\begin{array}{l}\text { An infusion of leaves } \\
\text { is used as inhalation } \\
\text { for respiratory } \\
\text { diseases. }\end{array}$ \\
\hline 100. & $\begin{array}{l}\text { Eupatorium } \\
\text { album L. }\end{array}$ & 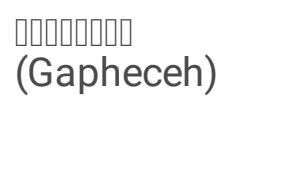 & Asteraceae & $\begin{array}{l}\text { Ap, } \\
\mathrm{R}\end{array}$ & 0.083 & $\begin{array}{l}\text { An infusion of aerial } \\
\text { part and roots is used } \\
\text { as expectorant and } \\
\text { diuretic. }\end{array}$ \\
\hline 101. & $\begin{array}{l}\text { Euphorbia } \\
\text { paralias L. }\end{array}$ & 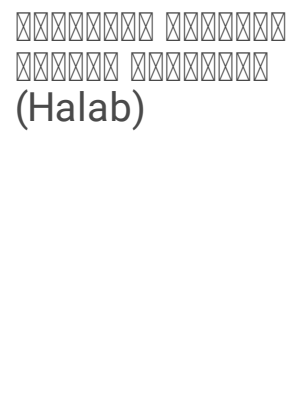 & Euphorbiaceae & $\begin{array}{l}\mathrm{R}, \\
\mathrm{Rm}\end{array}$ & 0.247 & $\begin{array}{l}\text { A decoction of roots } \\
\text { and rhizomes is used } \\
\text { for getting rid of } \\
\text { phlegm and relieving } \\
\text { congestion of the } \\
\text { respiratory system, } \\
\text { for cases of gout and } \\
\text { arthritis, and it is } \\
\text { used in cases of } \\
\text { constipation. }\end{array}$ \\
\hline
\end{tabular}




\begin{tabular}{|c|c|c|c|c|c|c|}
\hline No. & $\begin{array}{l}\text { Name of } \\
\text { Species }\end{array}$ & $\begin{array}{l}\text { Common } \\
\text { Name (Arabic } \\
\text { Language) }\end{array}$ & Family & $\begin{array}{l}\text { Part } \\
\text { Used }\end{array}$ & MUV & Ethnobotanical Uses \\
\hline 102. & Ficus carica L. & प्राप्र (At-tīn) & Moraceae & $\mathrm{F}$ & 0.818 & $\begin{array}{l}\text { The dried fruits } \\
\text { externally for } \\
\text { wounds, the milk of } \\
\text { the fruit is used } \\
\text { topical for warts, } \\
\text { orally the decoction is } \\
\text { used for catarrh and } \\
\text { bronchitis, and for } \\
\text { diabetes, } \\
\text { hypertriglyceridemia, } \\
\text { laxative. }\end{array}$ \\
\hline 103. & $\begin{array}{l}\text { Filipendula } \\
\text { ulmaria L. } \\
\text { Maxim. }\end{array}$ & 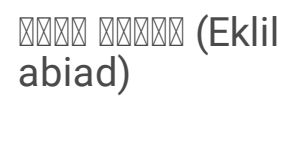 & Rosaceae & Ap & 0.061 & $\begin{array}{l}\text { An infusion of aerial } \\
\text { parts is used as } \\
\text { diuretic. }\end{array}$ \\
\hline 104. & $\begin{array}{l}\text { Foeniculum } \\
\text { vulgare L. }\end{array}$ & प्राप्र (Shomra) & Apiaceae & Sd & 0.527 & $\begin{array}{l}\text { An infusion of seeds } \\
\text { is used as } \\
\text { carminative, } \\
\text { digestive, increased } \\
\text { breast milk and } \\
\text { diuretic and in } \\
\text { treating of } \\
\text { respiratory and } \\
\text { gastrointestinal } \\
\text { disorders. }\end{array}$ \\
\hline 105. & $\begin{array}{l}\text { Frankenia } \\
\text { hirsute L. }\end{array}$ & $\begin{array}{l}\text { (Hamrah) } \\
\text { (Hambents }\end{array}$ & Frankeniaceae & W & 0.007 & $\begin{array}{l}\text { A herb is used in } \\
\text { cosmetics due to its } \\
\text { astringent action. }\end{array}$ \\
\hline 106. & $\begin{array}{l}\text { Fraxinus } \\
\text { Syriaca L. }\end{array}$ & पराप्र (Dardar) & Oleaceae & $\mathrm{L}$ & 0.527 & $\begin{array}{l}\text { An infusion of leaves } \\
\text { is used for facilitate } \\
\text { digestion, treat } \\
\text { tracheitis, } \\
\text { strengthening the } \\
\text { immune system, it is } \\
\text { famous for its honey } \\
\text { of which is called } \\
\text { (Asal El-Dardar) } \\
\text { means Syrian ash- } \\
\text { tree honey. }\end{array}$ \\
\hline 107. & $\begin{array}{l}\text { Fumana } \\
\text { thymifolia (L.) } \\
\text { Spach }\end{array}$ & 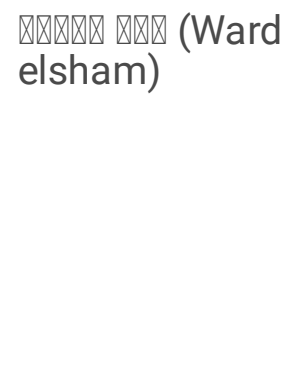 & Cistaceae & Ap & 0.003 & $\begin{array}{l}\text { An infusion of aerial } \\
\text { parts is used against } \\
\text { common cold, flu and } \\
\text { as diuretic and } \\
\text { analgesic properties } \\
\text { and it is } \\
\text { recommended for } \\
\text { pain during } \\
\text { menstruation. }\end{array}$ \\
\hline 108. & $\begin{array}{l}\text { Galium aparine } \\
\text { L. }\end{array}$ & $\begin{array}{l}\text { (Bulsaka) } \\
\text { (Balsaka }\end{array}$ & Rubiaceae & Ap & 0.014 & $\begin{array}{l}\text { An infusion of aerial } \\
\text { parts is used as } \\
\text { diuretic. }\end{array}$ \\
\hline
\end{tabular}




\begin{tabular}{|c|c|c|c|c|c|c|}
\hline No. & $\begin{array}{l}\text { Name of } \\
\text { Species }\end{array}$ & $\begin{array}{l}\text { Common } \\
\text { Name (Arabic } \\
\text { Language) }\end{array}$ & Family & $\begin{array}{l}\text { Part } \\
\text { Used }\end{array}$ & MUV & Ethnobotanical Uses \\
\hline 109. & $\begin{array}{l}\text { Genista } \\
\text { acanthoclada } \\
\text { DC. }\end{array}$ & प्राप्रा (Shweek) & Fabaceae & Ap & 0.018 & $\begin{array}{l}\text { An infusion of aerial } \\
\text { parts is used to } \\
\text { treatment of the } \\
\text { respiratory diseases, } \\
\text { rheumatic disorders, } \\
\text { diabetes and ulcer. }\end{array}$ \\
\hline 110. & $\begin{array}{l}\text { Geranium } \\
\text { crenophilum } \\
\text { Boiss. }\end{array}$ & 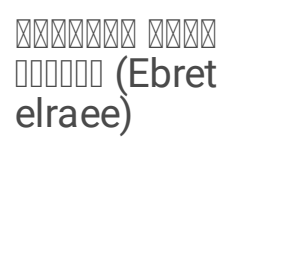 & Geraniaceae & $\mathrm{FI}$ & 0.127 & $\begin{array}{l}\text { An infusion of } \\
\text { flowering herb as } \\
\text { analgesic and } \\
\text { antiseptic and topical } \\
\text { is used to stopped } \\
\text { bleeding. }\end{array}$ \\
\hline 111. & $\begin{array}{l}\text { Gladiolus } \\
\text { segetum Ker } \\
\text { Gawl. }\end{array}$ & 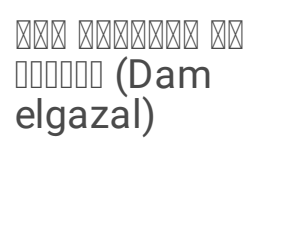 & Iridaceae & Ap & 0.083 & $\begin{array}{l}\text { An infusion of aerial } \\
\text { parts is used for } \\
\text { stomach pain, } \\
\text { delayed } \\
\text { menstruation, gout. }\end{array}$ \\
\hline 112. & $\begin{array}{l}\text { Glaucium } \\
\text { flavum Crantz }\end{array}$ & 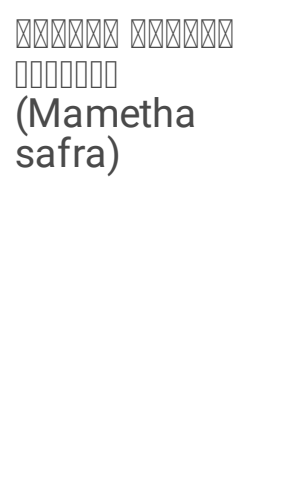 & Papaveraceae & W & 0.098 & $\begin{array}{l}\text { A decoction of whole } \\
\text { plant is used in the } \\
\text { treatment of wounds, } \\
\text { burns and } \\
\text { hemorrhoids, and it is } \\
\text { used in the form of } \\
\text { cough medicines and } \\
\text { is used as a mild } \\
\text { sedative. It was used } \\
\text { in the past as a } \\
\text { diuretic and } \\
\text { galactagogue. }\end{array}$ \\
\hline 113. & $\begin{array}{l}\text { Gundelia } \\
\text { tournifortii L. }\end{array}$ & 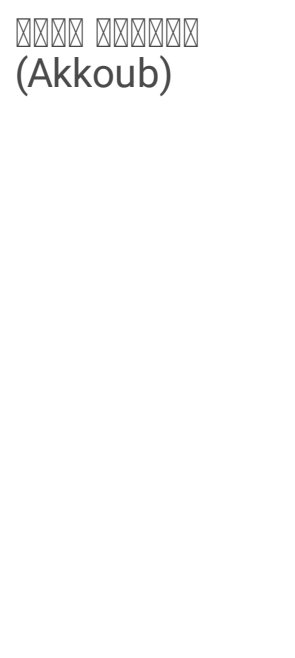 & Asteraceae & $\begin{array}{l}\mathrm{R}, \mathrm{S}, \\
\mathrm{L}\end{array}$ & 0.636 & $\begin{array}{l}\text { A decoction of roots } \\
\text { and stems is used for } \\
\text { improving digestion, } \\
\text { and increasing sexual } \\
\text { ability in both sexes, } \\
\text { and treating diabetes, } \\
\text { also it is used as liver } \\
\text { tonic, anti- } \\
\text { constipation, and the } \\
\text { fresh leaves are used } \\
\text { within traditional } \\
\text { recipes in food after } \\
\text { removing the spines, } \\
\text { where it is boiled and } \\
\text { then fried in ghee or } \\
\text { olive oil. }\end{array}$ \\
\hline
\end{tabular}




\begin{tabular}{|c|c|c|c|c|c|c|}
\hline & $\begin{array}{l}\text { Name of } \\
\text { Snecies }\end{array}$ & Common & Family & $\begin{array}{l}\text { Part } \\
\text { Used }\end{array}$ & MUV & Ethnobotanical Uses \\
\hline No. & & $\begin{array}{l}\text { Name (Arab } \\
\text { Language) }\end{array}$ & & & & \\
\hline
\end{tabular}

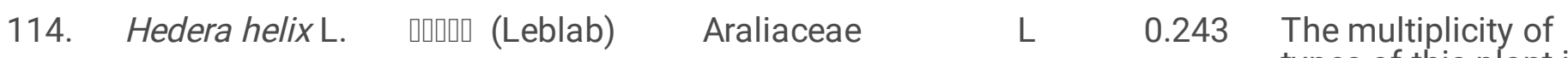
types of this plant in Syria, including the small "ivy", the madadeh Calystegia sepium (L.) R. Br., the Convolvulus arvensis L. field ivy, and the "crow's cowl", and the commonly used is the Convolvulus althaeoides $\mathrm{L}$. "khatami ivy" widely spread in coastal villages, and it is used as animal fodder because they contain great nutritional value that reflects positively on production. also a decoction of leaves is used externally for to treat arthritis and warts, and for treatment of sores, wounds, burns, and fingernails as a dermal paste which it is placed on the affected places.

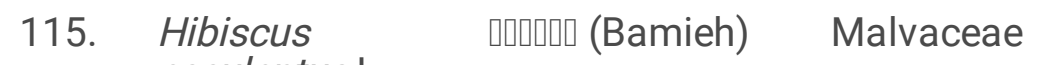
esculentus $\mathrm{L}$.

$\begin{array}{ll}\mathrm{F}_{\text {, }} & 0.098 \\ \mathrm{P} & \end{array}$

An edible pod-like fruits can be used fresh or dried, an infusion of the roasted seeds is used to treat diabetes, it facilitates the digestion process, due to its high content of fiber, it is used in the treatment of sore throats, arthritis, asthma, and urinary infections. 


\begin{tabular}{|c|c|c|c|c|c|c|}
\hline No. & $\begin{array}{l}\text { Name of } \\
\text { Species }\end{array}$ & $\begin{array}{l}\text { Common } \\
\text { Name (Arabic } \\
\text { Language) }\end{array}$ & Family & $\begin{array}{l}\text { Part } \\
\text { Used }\end{array}$ & MUV & Ethnobotanical Uses \\
\hline 116. & $\begin{array}{l}\text { Hordeum } \\
\text { bulbosum } \mathrm{L} .\end{array}$ & 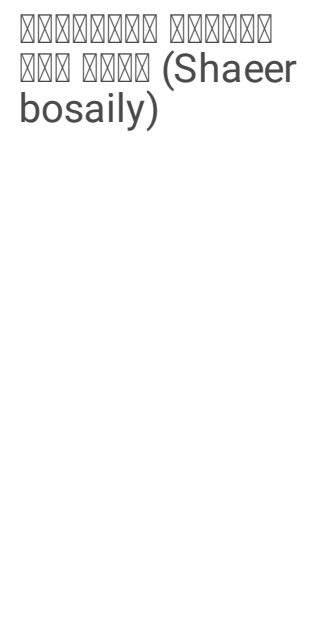 & Poaceae & W & 0.141 & $\begin{array}{l}\text { The barley water as } \\
\text { infusion is used the } \\
\text { chest pain, coughs, } \\
\text { and topically used for } \\
\text { scabies, and } \\
\text { melasma, and the } \\
\text { barley tea as } \\
\text { decoction is used as } \\
\text { diuretic and anti- } \\
\text { constipation, and for } \\
\text { the treatment of } \\
\text { common colds, and } \\
\text { nerve infections, also } \\
\text { the sprouted barley is } \\
\text { used as antioxidant. }\end{array}$ \\
\hline 117. & $\begin{array}{l}\text { Humulus } \\
\text { lupulus } \mathrm{L} \text {. }\end{array}$ & 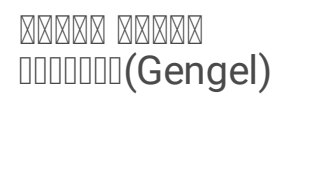 & Cannabaceae & $\mathrm{FI}$ & 0.41 & $\begin{array}{l}\text { An infusion of } \\
\text { flowering parts is } \\
\text { used as anxiolytic, } \\
\text { and digestive tonic. }\end{array}$ \\
\hline 118. & $\begin{array}{l}\text { Hypecoum } \\
\text { pendulum } \mathrm{L} .\end{array}$ & $\begin{array}{l}\text { Q } \\
\text { (Barbara } \\
\text { penduleh) }\end{array}$ & Papaveraceae & $\mathrm{R}$ & 0.01 & $\begin{array}{l}\text { A decoction of roots } \\
\text { is used as diaphoretic } \\
\text { and diuretic. }\end{array}$ \\
\hline 119. & $\begin{array}{l}\text { Hypericum } \\
\text { perforatum } \mathrm{L} \text {. }\end{array}$ & 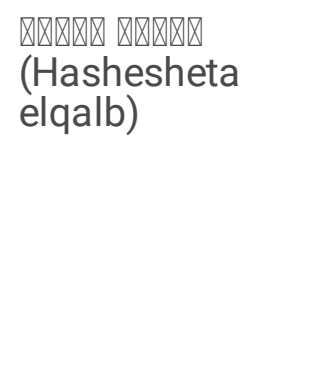 & Hypericaceae & Ap & 0.341 & $\begin{array}{l}\text { An infusion of aerial } \\
\text { parts is used } \\
\text { internally for cases of } \\
\text { constipation and } \\
\text { spasms, and as } \\
\text { antiseptic and } \\
\text { analgesic, externally } \\
\text { for the treatment of } \\
\text { wounds and ulcers. }\end{array}$ \\
\hline 120. & $\begin{array}{l}\text { Hypericum } \\
\text { triquetrifolium } \\
\text { Turra. }\end{array}$ & प्रा (Aran) & Hypericaceae & $\mathrm{FI}$ & 0.243 & $\begin{array}{l}\text { An infusion of } \\
\text { flowers is used as } \\
\text { anxiolytic, and } \\
\text { antidepressant. }\end{array}$ \\
\hline 121. & $\begin{array}{l}\text { Inula viscosa } \\
\text { L. }\end{array}$ & 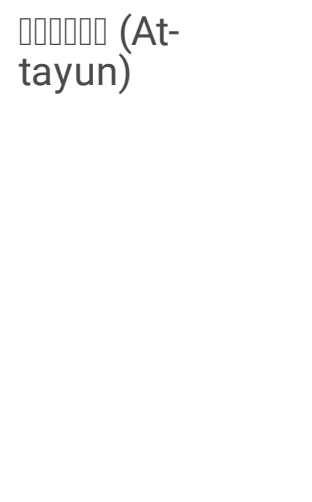 & Asteraceae & $\mathrm{L}, \mathrm{Fl}$ & 0.694 & $\begin{array}{l}\text { A decoction of } \\
\text { leaves is used } \\
\text { externally for burns, } \\
\text { wounds, cutaneous } \\
\text { leishmaniasis, and } \\
\text { the oil of the flowers } \\
\text { is prepared in olive oil } \\
\text { to use topically. and it } \\
\text { is used orally for } \\
\text { anemia, respiratory } \\
\text { problems, ulcers of } \\
\text { the gums, diarrea. }\end{array}$ \\
\hline
\end{tabular}




\begin{tabular}{|c|c|c|c|c|c|c|}
\hline No. & $\begin{array}{l}\text { Name of } \\
\text { Species }\end{array}$ & $\begin{array}{l}\text { Common } \\
\text { Name (Arabic } \\
\text { Language) }\end{array}$ & Family & $\begin{array}{l}\text { Part } \\
\text { Used }\end{array}$ & MUV & Ethnobotanical Uses \\
\hline 122. & $\begin{array}{l}\text { Iris } \\
\text { unguicularis } \\
\text { Poir. }\end{array}$ & 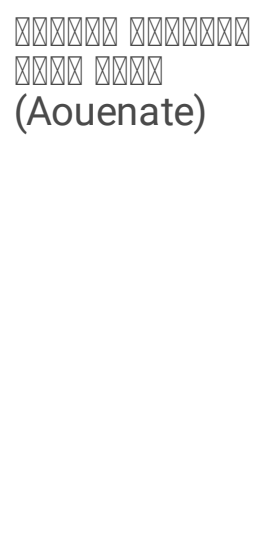 & Iridaceae & $\begin{array}{l}\text { Sd, } \\
\text { L, } \\
\text { Rm, } \\
\mathrm{Fl}\end{array}$ & 0.04 & $\begin{array}{l}\text { An infusion of seeds, } \\
\text { rhizomes, leaves and } \\
\text { flowers is used for } \\
\text { treating colds, } \\
\text { influenza, malaria, } \\
\text { toothache, trauma } \\
\text { and for diabetics, and } \\
\text { the volatile oil is used } \\
\text { for preparing } \\
\text { perfume is used due } \\
\text { to its aromatic smell } \\
\text { close to the smell of } \\
\text { violet. }\end{array}$ \\
\hline 123. & $\begin{array}{l}\text { Jasminum } \\
\text { fruticans L. }\end{array}$ & $\begin{array}{l}\text { (Yasmin bari) } \\
\text { (Yasm }\end{array}$ & Oleaceae & $\mathrm{Fl}$ & 0.16 & $\begin{array}{l}\text { An infusion of } \\
\text { flowers is used } \\
\text { internally to relieve } \\
\text { liver pain resulting } \\
\text { from its } \\
\text { inflammation, it is } \\
\text { used in the treatment } \\
\text { of stomach and } \\
\text { intestinal pain and } \\
\text { headache as a result } \\
\text { of burning heat } \\
\text { stroke, and it is also } \\
\text { used externally in the } \\
\text { treatment of skin } \\
\text { ulcers and burns. }\end{array}$ \\
\hline 124. & $\begin{array}{l}\text { Juglans regia } \\
\text { L. }\end{array}$ & प्रा (Jauz) & Juglandaceae & $\begin{array}{l}S d \\
F, L\end{array}$ & 0.86 & $\begin{array}{l}\text { A decoction of seeds } \\
\text { and leaves is used } \\
\text { orally for sexual } \\
\text { impotency, blood } \\
\text { purification, lymph } \\
\text { gland enlargement, } \\
\text { and bleeding, and } \\
\text { topically is used for } \\
\text { scrofula disease, } \\
\text { sores, blisters, the } \\
\text { fresh fruits are used } \\
\text { for poor memory, } \\
\text { strengthen immunity. }\end{array}$ \\
\hline 125. & $\begin{array}{l}\text { Juncus acutus } \\
\text { L. }\end{array}$ & 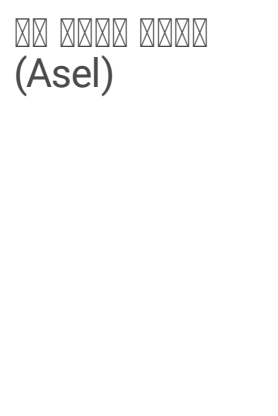 & Juncaceae & $\begin{array}{l}\mathrm{Sd} \\
\mathrm{R}\end{array}$ & 0.083 & $\begin{array}{l}\text { This is a toxic plant, } \\
\text { but rarely a decoction } \\
\text { of seeds is used for } \\
\text { treatment diarrhea, } \\
\text { anemia, and as } \\
\text { hypoallergenic, and a } \\
\text { decoction of roots is } \\
\text { used in the treatment } \\
\text { of some skin } \\
\text { diseases. }\end{array}$ \\
\hline
\end{tabular}




\begin{tabular}{|c|c|c|c|c|c|c|}
\hline No. & $\begin{array}{l}\text { Name of } \\
\text { Species }\end{array}$ & $\begin{array}{l}\text { Common } \\
\text { Name (Arabic } \\
\text { Language) }\end{array}$ & Family & $\begin{array}{l}\text { Part } \\
\text { Used }\end{array}$ & MUV & Ethnobotanical Uses \\
\hline 126. & $\begin{array}{l}\text { Juniperus } \\
\text { communis L. }\end{array}$ & प्रा (Arâr) & Cupressaceae & $\mathrm{F}$ & 0.549 & $\begin{array}{l}\text { A decoction of fruits } \\
\text { is used for } \\
\text { rheumatism, } \\
\text { paralysis, } \\
\text { tuberculosis, anemia, } \\
\text { diuretic, and for } \\
\text { urinary tract } \\
\text { infection. }\end{array}$ \\
\hline 127. & $\begin{array}{l}\text { Juniperus } \\
\text { drupacea } \\
\text { Labill. }\end{array}$ & 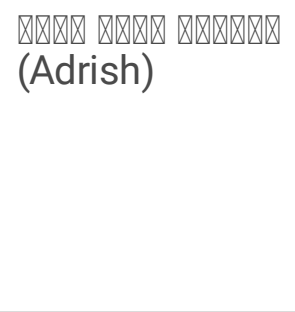 & Cupressaceae & $\mathrm{F}$ & 0.043 & $\begin{array}{l}\text { A decoction of the } \\
\text { Syrian juniper fruits is } \\
\text { used for treating the } \\
\text { nervous disorders, } \\
\text { kidney and bladder } \\
\text { diseases, and used } \\
\text { as antispasmodic. }\end{array}$ \\
\hline 128. & $\begin{array}{l}\text { Juniperus } \\
\text { oxycedrus L. }\end{array}$ & 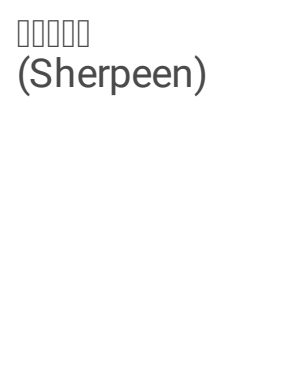 & Cupressaceae & $\mathrm{F}$ & 0.105 & $\begin{array}{l}\text { Decoction of berries } \\
\text { was used internally } \\
\text { as tea for diabetes, } \\
\text { obesity, bronchitis, } \\
\text { and pneumonia, and } \\
\text { externally is used for } \\
\text { chronic eczema and } \\
\text { other several skin } \\
\text { diseases. }\end{array}$ \\
\hline
\end{tabular}




\begin{tabular}{|c|c|c|c|c|c|c|}
\hline No. & $\begin{array}{l}\text { Name of } \\
\text { Species }\end{array}$ & $\begin{array}{l}\text { Common } \\
\text { Name (Arabic } \\
\text { Language) }\end{array}$ & Family & $\begin{array}{l}\text { Part } \\
\text { Used }\end{array}$ & MUV & Ethnobotanical Uses \\
\hline 129. & $\begin{array}{l}\text { Lactuca } \\
\text { saligna L. }\end{array}$ & $\begin{array}{l}\text { 财 (Khas } \\
\text { bari) }\end{array}$ & Asteraceae & L & 0.127 & $\begin{array}{l}\text { A decoction of leaves } \\
\text { drink before bed for } \\
\text { those who suffer } \\
\text { from insomnia. } \\
\text { because of its } \\
\text { analgesic property, it } \\
\text { is used to relieve } \\
\text { intestinal colic pain in } \\
\text { cases of irritable } \\
\text { bowel syndrome. It is } \\
\text { used in mental } \\
\text { illnesses as a } \\
\text { sedative for nerves } \\
\text { and as a remedy for } \\
\text { tension and } \\
\text { frustration, and } \\
\text { epilepsy and also } \\
\text { removes depression, } \\
\text { also lettuce leaves } \\
\text { infusion is used to } \\
\text { increase sweating, } \\
\text { relieve gout, and as } \\
\text { antipyretic, diuretic, } \\
\text { and to remove stones } \\
\text { from the kidneys, } \\
\text { also used to } \\
\text { eliminate thirst and it } \\
\text { is useful in cases of } \\
\text { summer heat and } \\
\text { sunstroke, and as } \\
\text { tonic, aperitif, and a } \\
\text { decoction of leaves is } \\
\text { used externally as a } \\
\text { tonic for hair. }\end{array}$ \\
\hline 130. & $\begin{array}{l}\text { Lamium album } \\
\text { L. }\end{array}$ & प्राप्रा (Lamiun) & Lamiaceae & $\mathrm{FI}$ & 0.04 & $\begin{array}{l}\text { A decoction of } \\
\text { flowers without calyx } \\
\text { is used as analgesic } \\
\text { and for gynecological } \\
\text { diseases. }\end{array}$ \\
\hline 131. & $\begin{array}{l}\text { Lathyrus } \\
\text { aphaca L. }\end{array}$ & 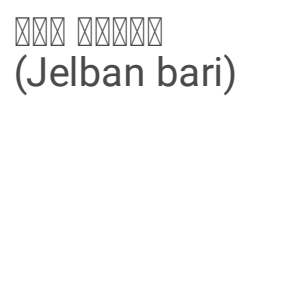 & Fabaceae & $\mathrm{Sd}$ & 0.061 & $\begin{array}{l}\text { The seeds - cooked, } \\
\text { only use when } \\
\text { immature is used for } \\
\text { respiratory tract } \\
\text { infection, and anti- } \\
\text { obesity, anti- } \\
\text { constipation. }\end{array}$ \\
\hline
\end{tabular}




\begin{tabular}{|c|c|c|c|c|c|c|}
\hline No. & $\begin{array}{l}\text { Name of } \\
\text { Species }\end{array}$ & $\begin{array}{l}\text { Common } \\
\text { Name (Arabic } \\
\text { Language) }\end{array}$ & Family & $\begin{array}{l}\text { Part } \\
\text { Used }\end{array}$ & MUV & Ethnobotanical Uses \\
\hline
\end{tabular}
132. Lagenaria $\quad$ Cucurbitaceae Sd 0.207 A decoction of seed siceraria (Molina) (Qarea

elyaqteen)

Standl. and its oil is used internally for cases of high blood pressure, kidney disease as diuretic, it is useful for liver, stomach, intestine, diabetes, obesity, and for removing worms and topically is used for rashes.

133. Laurus nobilis $\quad$ प(Gar) L.

Lauraceae

L, F $\quad 0.923$

The industry of

Aleppo laurel soap in Syria from laurel oil in the Syrian coast, especially the Kassab region with olive oil, and this industry has developed so that it produces one of the best types of soap in the world. An infusion of leaves is used to treat common cold, flu, and bronchitis, to facilitate digestion, appetite, stomach and intestinal infections, diabetics, relief from fatigue and psychological frustration, and used as body refreshment, and for migraine and headache relief. Gargle with laurel leaves water, which helps to clean the mouth, throat and nose, and to calm tooth ache. Laurel fruits oil is used externally to relieve rheumatism, joint and muscle pain, treat mycosis, skin diseases, psoriasis, and treat boils and premolars. Aromatic laurel leaves water is used for cosmetic purposes, to cleanse the face, and to relieve acne and pimples. 


\begin{tabular}{|c|c|c|c|c|c|c|}
\hline No. & $\begin{array}{l}\text { Name of } \\
\text { Species }\end{array}$ & $\begin{array}{l}\text { Common } \\
\text { Name (Arabic } \\
\text { Language) }\end{array}$ & Family & $\begin{array}{l}\text { Part } \\
\text { Used }\end{array}$ & MUV & Ethnobotanical Uses \\
\hline 134. & $\begin{array}{l}\text { Lavandula } \\
\text { stoechas } \mathrm{L} \text {. }\end{array}$ & $\begin{array}{l}\text { (Khozama) } \\
\text { (Khozamale }\end{array}$ & Lamiaceae & Ap & 0.774 & $\begin{array}{l}\text { A decoction of aerial } \\
\text { parts is used } \\
\text { antispasmodic in } \\
\text { colic pain and for } \\
\text { various diseases of } \\
\text { the central nervous } \\
\text { system, such as } \\
\text { epilepsy and } \\
\text { migraine and urinary } \\
\text { tract infections, also } \\
\text { used as analgesic, } \\
\text { sedative and } \\
\text { antiseptic properties., } \\
\text { while a decoction of } \\
\text { aerial parts is used } \\
\text { topically for wounds, } \\
\text { and eczema. }\end{array}$ \\
\hline
\end{tabular}




\begin{tabular}{|c|c|c|c|c|c|c|}
\hline No. & $\begin{array}{l}\text { Name of } \\
\text { Species }\end{array}$ & $\begin{array}{l}\text { Common } \\
\text { Name (Arabic } \\
\text { Language) }\end{array}$ & Family & $\begin{array}{l}\text { Part } \\
\text { Used }\end{array}$ & MUV & Ethnobotanical Uses \\
\hline 135. & $\begin{array}{l}\text { Lavatera } \\
\text { punctata All. }\end{array}$ & $\begin{array}{l}\text { (Khobezeh) } \\
\text { (Khober }\end{array}$ & Malvaceae & $\mathrm{L}, \mathrm{FI}$ & 0.916 & $\begin{array}{l}\text { A decoction of leaves } \\
\text { are used in cases of } \\
\text { bronchitis, cough } \\
\text { accompanied by dry } \\
\text { sputum that makes it } \\
\text { easier to pass and } \\
\text { harshness of the } \\
\text { voice, and as a } \\
\text { sedative to relieve } \\
\text { minor pain and } \\
\text { inflammation of the } \\
\text { membranes, it can } \\
\text { also be used to treat } \\
\text { inflammation of the } \\
\text { digestive system and } \\
\text { is useful in relieving } \\
\text { constipation, ulcers, } \\
\text { hemorrhoids, urinary } \\
\text { system infections } \\
\text { and used as diuretics, } \\
\text { useful in case } \\
\text { asthenia. It can also } \\
\text { be used externally to } \\
\text { treat skin diseases } \\
\text { and used for wounds, } \\
\text { sores, insect stings } \\
\text { and hemorrhoids. A } \\
\text { decoction of flowers } \\
\text { is used as a pain } \\
\text { reliever for throat } \\
\text { pain and used as a } \\
\text { gargle for the mouth } \\
\text { and throat. Also the } \\
\text { mucilage of leaves is } \\
\text { also useful for the } \\
\text { skin and used for } \\
\text { preparing cosmetic } \\
\text { creams that nourish } \\
\text { the skin and remove } \\
\text { wrinkles, it is also } \\
\text { used in the } \\
\text { manufacture of soap } \\
\text { and shampoo. } \\
\text { Making dips with } \\
\text { boiled mallow leaves } \\
\text { soothes uterine } \\
\text { congestion. }\end{array}$ \\
\hline
\end{tabular}




\begin{tabular}{|c|c|c|c|c|c|c|}
\hline No. & $\begin{array}{l}\text { Name of } \\
\text { Species }\end{array}$ & $\begin{array}{l}\text { Common } \\
\text { Name (Arabic } \\
\text { Language) }\end{array}$ & Family & $\begin{array}{l}\text { Part } \\
\text { Used }\end{array}$ & MUV & Ethnobotanical Uses \\
\hline 136. & $\begin{array}{l}\text { Lepidium } \\
\text { sativum L. }\end{array}$ & प्राप (Rashad) & Brassicaceae & L, Sd & 0.487 & $\begin{array}{l}\text { A decoction of leaves } \\
\text { is used for kidney } \\
\text { disorders, diuretic, } \\
\text { kidney stone, to } \\
\text { increase breast milk } \\
\text { in female, and tonic, } \\
\text { it used to regulate the } \\
\text { menstrual cycle in } \\
\text { women, and to } \\
\text { reduce blood sugar } \\
\text { for diabetics. and } \\
\text { triglyceride levels and } \\
\text { blood cholesterol } \\
\text { level, the oil of seed is } \\
\text { used as hair tonic. }\end{array}$ \\
\hline 137. & $\begin{array}{l}\text { Linum } \\
\text { pubescens L. }\end{array}$ & प्राप (kettan) & Linaceae & Sd & 0.25 & $\begin{array}{l}\text { Seeds oil is used as } \\
\text { laxative and for } \\
\text { obesity. The seeds } \\
\text { are used in treatment } \\
\text { of urinary tract } \\
\text { infections and } \\
\text { hypertriglyceridemia. }\end{array}$ \\
\hline 138. & $\begin{array}{l}\text { Lonicera } \\
\text { orientalis Lam. }\end{array}$ & 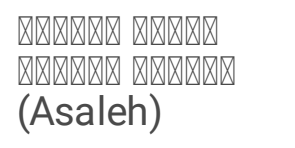 & Caprifoliaceae & Ap & 0.05 & $\begin{array}{l}\text { An infusion of aerial } \\
\text { parts is used for } \\
\text { respiratory infections. }\end{array}$ \\
\hline 139. & $\begin{array}{l}\text { Lotus } \\
\text { corniculatus L. }\end{array}$ & 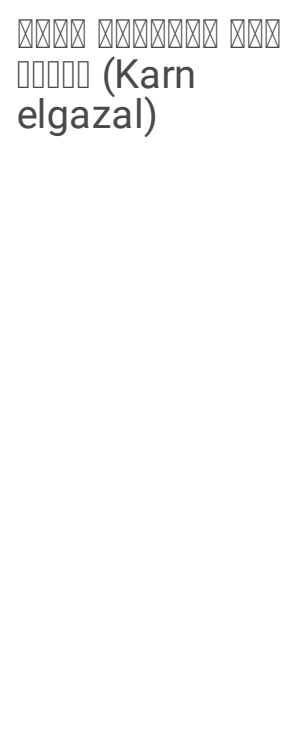 & Fabaceae & $\mathrm{R}, \mathrm{T}$ & 0.04 & $\begin{array}{l}\text { An infusion of roots } \\
\text { is used for } \\
\text { constipation and } \\
\text { snakebite, and } \\
\text { prostate diseases, } \\
\text { peptic ulcers, helps to } \\
\text { eliminate the problem } \\
\text { of frequent urination, } \\
\text { cough, treatment of } \\
\text { rheumatism, diarrhea. } \\
\text { The tubers powder is } \\
\text { used externally in } \\
\text { getting rid of boils } \\
\text { and burns, especially } \\
\text { in diabetics, and in } \\
\text { the treatment of fungi } \\
\text { and nail fungi that } \\
\text { grow on the skin. }\end{array}$ \\
\hline 140. & $\begin{array}{l}\text { Lotus gebelia } \\
\text { Vent. }\end{array}$ & 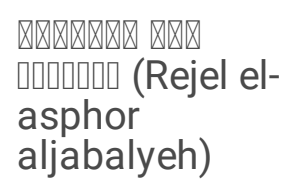 & Fabaceae & $\mathrm{R}$ & 0.014 & $\begin{array}{l}\text { A decoction of roots } \\
\text { is used as diaphoretic } \\
\text { and carminative. }\end{array}$ \\
\hline
\end{tabular}




\begin{tabular}{|c|c|c|c|c|c|c|}
\hline No. & $\begin{array}{l}\text { Name of } \\
\text { Species }\end{array}$ & $\begin{array}{l}\text { Common } \\
\text { Name (Arabic } \\
\text { Language) }\end{array}$ & Family & $\begin{array}{l}\text { Part } \\
\text { Used }\end{array}$ & MUV & Ethnobotanical Uses \\
\hline 141. & $\begin{array}{l}\text { Malus } \\
\text { silvestris } \mathrm{L} \text {. } \\
\text { Mill. }\end{array}$ & प्राप (Tofah) & Rosaceae & $\mathrm{F}$ & 0.89 & $\begin{array}{l}\text { Apple cider vinegar is } \\
\text { used orally for } \\
\text { slimming and } \\
\text { reducing blood lipids, } \\
\text { externally, it is used } \\
\text { to treat skin diseases, } \\
\text { remove corns, and as } \\
\text { an antiseptic, and to } \\
\text { treat lichen. }\end{array}$ \\
\hline 142. & $\begin{array}{l}\text { Malva } \\
\text { sylvestris L. }\end{array}$ & $\begin{array}{l}\text { (Khubbeizeh) } \\
\text { (Khubber }\end{array}$ & Malvaceae & $\mathrm{L}, \mathrm{FI}$ & 0.916 & $\begin{array}{l}\text { A decoction of leaves } \\
\text { and flowers is used } \\
\text { orally for cough as } \\
\text { expectorant, sedative } \\
\text { for sleep problems, } \\
\text { digestion problems, } \\
\text { and mouth sores, and } \\
\text { externally for skin } \\
\text { diseases. }\end{array}$ \\
\hline 143. & $\begin{array}{l}\text { Marrubium } \\
\text { vulgare L. }\end{array}$ & 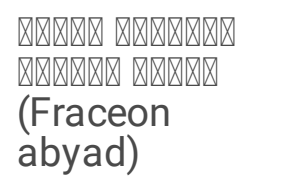 & Lamiaceae & L & 0.08 & $\begin{array}{l}\text { A decoction of leaves } \\
\text { is used as } \\
\text { expectorant. }\end{array}$ \\
\hline 144. & $\begin{array}{l}\text { Matricaria } \\
\text { aurea (Loefl.) } \\
\text { Sch.Bip. }\end{array}$ & 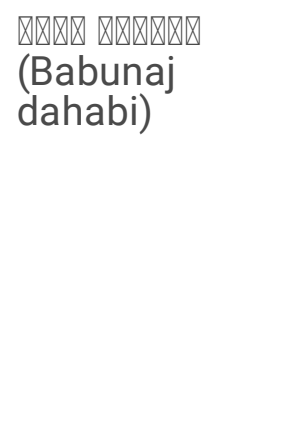 & Asteraceae & $\mathrm{FI}$ & 0.549 & $\begin{array}{l}\text { The flower decoction } \\
\text { or infusion is used } \\
\text { orally for fever, } \\
\text { coughing and heart } \\
\text { diseases, chest pain, } \\
\text { headache, and kidney } \\
\text { stone, and its used to } \\
\text { treat skin infections, } \\
\text { burns, wounds, } \\
\text { eczema. }\end{array}$ \\
\hline 145. & $\begin{array}{l}\text { Matricaria } \\
\text { chamomilla L. } \\
\text { (Loefl) Sch.Bip. }\end{array}$ & 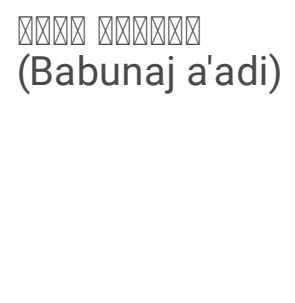 & Asteraceae & $\mathrm{FI}$ & 0.716 & $\begin{array}{l}\text { The flower decoction } \\
\text { or infusion is used } \\
\text { orally for chest } \\
\text { diseases, treatment } \\
\text { of stomach ache, } \\
\text { diabetes, } \\
\text { antispasmodic. }\end{array}$ \\
\hline
\end{tabular}




\begin{tabular}{|c|c|c|c|c|c|c|}
\hline No. & $\begin{array}{l}\text { Name of } \\
\text { Species }\end{array}$ & $\begin{array}{l}\text { Common } \\
\text { Name (Arabic } \\
\text { Language) }\end{array}$ & Family & $\begin{array}{l}\text { Part } \\
\text { Used }\end{array}$ & MUV & Ethnobotanical Uses \\
\hline 146. & $\begin{array}{l}\text { Medicago } \\
\text { ciliaris (L.) } \\
\text { Krock. }\end{array}$ & प्र (Fasa) & Fabaceae & $\mathrm{Fl}, \mathrm{L}$ & 0.407 & $\begin{array}{l}\text { An infusion of } \\
\text { flowers and leaves is } \\
\text { used to treat } \\
\text { menopause, diabetes, } \\
\text { respiratory infections, } \\
\text { dermatitis, } \\
\text { gastrointestinal } \\
\text { disorders, arthritis, } \\
\text { and kidney problems, } \\
\text { as it helps to increase } \\
\text { breast milk } \\
\text { production for } \\
\text { breastfeeding } \\
\text { mothers, and for } \\
\text { coughing. }\end{array}$ \\
\hline 147. & $\begin{array}{l}\text { Melia } \\
\text { azedarach L. }\end{array}$ & 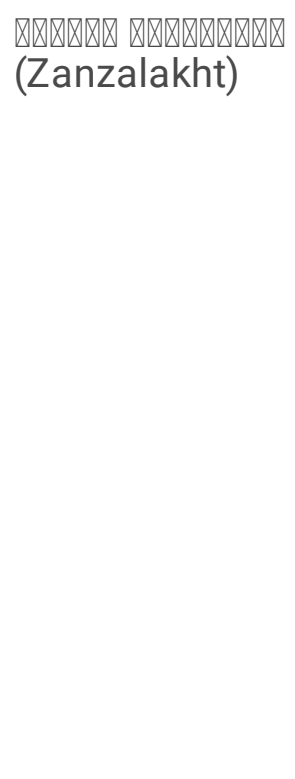 & Meliaceae & Sd, L & 0.134 & $\begin{array}{l}\text { The tree is a repellent } \\
\text { to insects and } \\
\text { mosquitoes, and the } \\
\text { seed oil is used } \\
\text { externally to } \\
\text { strengthen and } \\
\text { lengthen hair, and to } \\
\text { treat eczema, } \\
\text { cramping pain and } \\
\text { nerve pain, and boiled } \\
\text { leaves are also used } \\
\text { to prevent hair loss } \\
\text { and strengthen hair, } \\
\text { also housewives put } \\
\text { daisies and leaves } \\
\text { under bedspreads } \\
\text { and carpets so as not } \\
\text { to be exposed to the } \\
\text { moth. }\end{array}$ \\
\hline 148. & $\begin{array}{l}\text { Melica } \\
\text { angustifolia } \\
\text { Boiss. \& } \\
\text { Blanche. }\end{array}$ & $\begin{array}{l}\text { (Malika dayka) } \\
\text { (Malik }\end{array}$ & Poaceae & $\mathrm{FI}$ & 0.04 & $\begin{array}{l}\text { A decoction of } \\
\text { flowers is used as } \\
\text { diuretics and } \\
\text { antispasmodic, } \\
\text { analgesic and is used } \\
\text { to treat stomach } \\
\text { pain. One of the uses } \\
\text { of this plant is that it } \\
\text { is packed in small } \\
\text { bags and placed in } \\
\text { wardrobes for its } \\
\text { scented effect. }\end{array}$ \\
\hline 149. & $\begin{array}{l}\text { Melissa } \\
\text { officinalis L. }\end{array}$ & 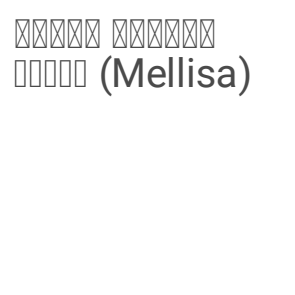 & Lamiaceae & $\mathrm{L}$ & 0.647 & $\begin{array}{l}\text { A decoction of leaves } \\
\text { is used orally as } \\
\text { carminative, } \\
\text { antispasmodic, } \\
\text { depression, anxiety, } \\
\text { cough, respiratory } \\
\text { infection. }\end{array}$ \\
\hline
\end{tabular}




\begin{tabular}{|c|c|c|c|c|c|c|}
\hline No. & $\begin{array}{l}\text { Name of } \\
\text { Species }\end{array}$ & $\begin{array}{l}\text { Common } \\
\text { Name (Arabic } \\
\text { Language) }\end{array}$ & Family & $\begin{array}{l}\text { Part } \\
\text { Used }\end{array}$ & MUV & Ethnobotanical Uses \\
\hline 150. & $\begin{array}{l}\text { Mentha } \\
\text { pulegium L. }\end{array}$ & $\begin{array}{l}\text { 叫 } \\
\text { bari) }\end{array}$ & Lamiaceae & L & 0.858 & $\begin{array}{l}\text { A decoction of leaves } \\
\text { is used orally as } \\
\text { antiseptic, menstrual } \\
\text { complaints, } \\
\text { diaphoretic, sedative, } \\
\text { itching, common } \\
\text { cold, respiratory tract } \\
\text { disorder, } \\
\text { antispasmodic. }\end{array}$ \\
\hline 151. & $\begin{array}{l}\text { Menyanthes } \\
\text { trifoliata L. }\end{array}$ & 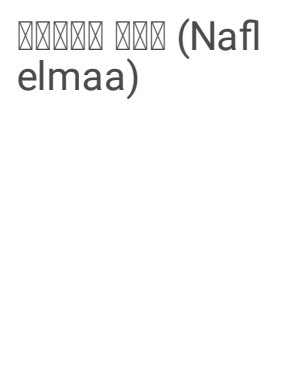 & Menyanthaceae & $\mathrm{L}$ & 0.083 & $\begin{array}{l}\text { A decoction of leaves } \\
\text { is used to treating } \\
\text { rheumatism and } \\
\text { arthritis, and } \\
\text { improving digestion, } \\
\text { increasing appetite } \\
\text { and weight, } \\
\text { stimulating secretion } \\
\text { of glands, and tonic. }\end{array}$ \\
\hline 152. & $\begin{array}{l}\text { Michauxia } \\
\text { campanuloides } \\
\text { L'Hér. }\end{array}$ & 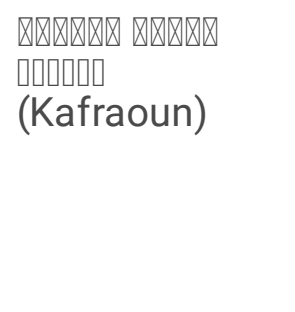 & Campanulaceae & $\begin{array}{l}\mathrm{R}, \mathrm{S}, \\
\mathrm{L}\end{array}$ & 0.15 & $\begin{array}{l}\text { Roots and stems are } \\
\text { peeled and eaten raw. } \\
\text { Young leaves are } \\
\text { sautéed with onions } \\
\text { and oil and used as a } \\
\text { nutritious and } \\
\text { digestive stimulant. }\end{array}$ \\
\hline 153. & $\begin{array}{l}\text { Micromeria } \\
\text { myrtifolia } \\
\text { Boiss. \& } \\
\text { Hohen. }\end{array}$ & प्राप (Zufa) & Lamiaceae & L & 0.632 & $\begin{array}{l}\text { A decoction of leaves } \\
\text { is used externally for } \\
\text { wounds, sores, skin } \\
\text { diseases, and its } \\
\text { used orally for colic } \\
\text { and cold, heart } \\
\text { diseases, digestive } \\
\text { system and asthma, } \\
\text { expectorant, } \\
\text { carminative. }\end{array}$ \\
\hline 154. & $\begin{array}{l}\text { Myrtus } \\
\text { communis } \mathrm{L} .\end{array}$ & 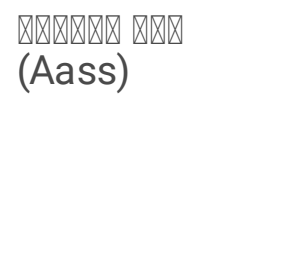 & Myrtaceae & $\mathrm{L}$ & 0.73 & $\begin{array}{l}\text { A decoction of leaves } \\
\text { is used for diarrhea, } \\
\text { respiratory tract } \\
\text { diseases, and } \\
\text { topically for } \\
\text { hemorrhoids. }\end{array}$ \\
\hline
\end{tabular}




\begin{tabular}{|c|c|c|c|c|c|c|}
\hline No. & $\begin{array}{l}\text { Name of } \\
\text { Species }\end{array}$ & $\begin{array}{l}\text { Common } \\
\text { Name (Arabic } \\
\text { Language) }\end{array}$ & Family & $\begin{array}{l}\text { Part } \\
\text { Used }\end{array}$ & MUV & Ethnobotanical Uses \\
\hline 155. & $\begin{array}{l}\text { Nigella sativa } \\
\text { L. }\end{array}$ & 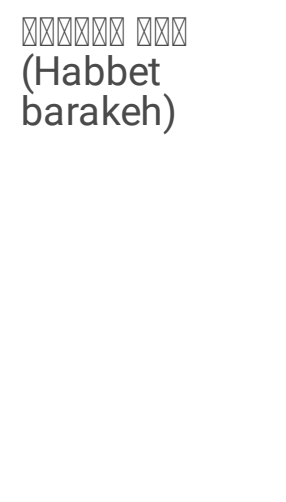 & Ranunculaceae & Sd & 0.738 & $\begin{array}{l}\text { Seeds are ground } \\
\text { finely and used as } \\
\text { expectorant, } \\
\text { carminative, } \\
\text { impotency in male, } \\
\text { antispasmodic, } \\
\text { hypoglycemic, oil } \\
\text { used topically for } \\
\text { skin diseases, hair } \\
\text { growth, and orally to } \\
\text { strengthen the body's } \\
\text { immunity. }\end{array}$ \\
\hline 156. & $\begin{array}{l}\text { Nerium } \\
\text { oleander L. }\end{array}$ & प्राप (Dephleh) & Apocynaceae & $F, R$ & 0.036 & $\begin{array}{l}\text { A toxic plant, rarely } \\
\text { the juice of fruits is } \\
\text { used topically with } \\
\text { careful } \\
\text { administration for } \\
\text { anal fissure, an oil } \\
\text { which is extracted } \\
\text { from the peel of the } \\
\text { roots is used for } \\
\text { topically treating } \\
\text { psoriasis and } \\
\text { dandruff diseases. }\end{array}$ \\
\hline 157. & $\begin{array}{l}\text { Olea europaea } \\
\text { L. }\end{array}$ & प्राप्र (Zaitoon) & Oleaceae & L & 0.934 & $\begin{array}{l}\text { A decoction of leaves } \\
\text { is used for diabetes, } \\
\text { high blood pressure, } \\
\text { and slimming, the } \\
\text { olive oil is used for } \\
\text { coughing, vasodilator, } \\
\text { laxative, hyperacidity } \\
\text { and stones in kidney, } \\
\text { and its used topically } \\
\text { for skin diseases. }\end{array}$ \\
\hline
\end{tabular}




\begin{tabular}{|c|c|c|c|c|c|c|}
\hline No. & $\begin{array}{l}\text { Name of } \\
\text { Species }\end{array}$ & $\begin{array}{l}\text { Common } \\
\text { Name (Arabic } \\
\text { Language) }\end{array}$ & Family & $\begin{array}{l}\text { Part } \\
\text { Used }\end{array}$ & MUV & Ethnobotanical Uses \\
\hline 158. & $\begin{array}{l}\text { Ononis hirta } \\
\text { Poir. \& Ononis } \\
\text { Spinosa L. }\end{array}$ & 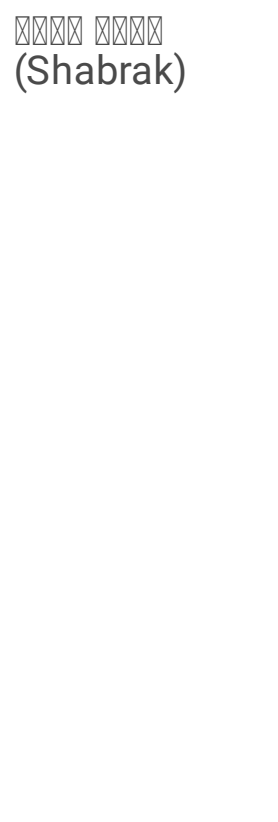 & Fabaceae & $\begin{array}{l}\mathrm{R}, \mathrm{Fl} \\
\mathrm{L}\end{array}$ & 0.054 & $\begin{array}{l}\text { A decoction of roots } \\
\text { is used to treat kidney } \\
\text { and bladder stones, } \\
\text { as a diuretic, and for } \\
\text { gout, cystitis, } \\
\text { excessive fluid } \\
\text { retention and } \\
\text { rheumatism, and is } \\
\text { also popularly used } \\
\text { for slimming and } \\
\text { antitussive. } \\
\text { Externally, it was } \\
\text { used for the healing } \\
\text { of wounds, eczema } \\
\text { and the other skin } \\
\text { disorders, also an } \\
\text { infusion of leaves } \\
\text { and flowers is used } \\
\text { as astringent, and } \\
\text { antiseptic. }\end{array}$ \\
\hline 159. & $\begin{array}{l}\text { Opuntia ficus- } \\
\text { indica L. Mill. }\end{array}$ & 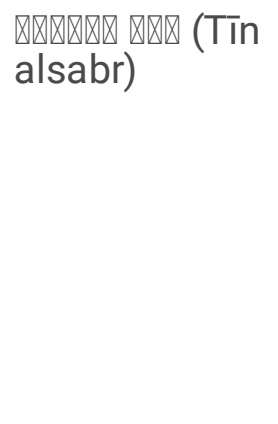 & Cactaceae & $F, L$ & 0.698 & $\begin{array}{l}\text { Fresh fruits and leaf } \\
\text { extract or juice are } \\
\text { used orally as } \\
\text { laxative, anti- } \\
\text { inflammatory, } \\
\text { carminative, } \\
\text { digestive, and are } \\
\text { used topically for sun } \\
\text { burns, skin care, burn, } \\
\text { wound. }\end{array}$ \\
\hline 160. & $\begin{array}{l}\text { Origanum } \\
\text { syriacum L. }\end{array}$ & 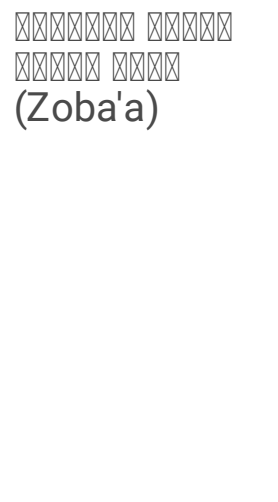 & Lamiaceae & Ap & 0.934 & $\begin{array}{l}\text { A decoction of aerial } \\
\text { parts is used for } \\
\text { catarrh, carminative, } \\
\text { diuretic, headache, } \\
\text { rheumatism, } \\
\text { antiseptic, neck } \\
\text { stiffness, stomach } \\
\text { cramps, stomach } \\
\text { discomfort, } \\
\text { indigestion, } \\
\text { cholesterol reduction, } \\
\text { expectorant, diuretic. }\end{array}$ \\
\hline 161. & $\begin{array}{l}\text { Orlaya } \\
\text { daucoides } \mathrm{L} . \\
\text { Greuter }\end{array}$ & 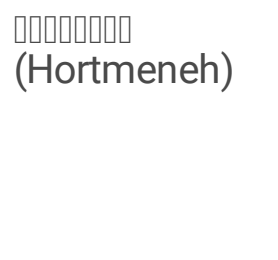 & Apiaceae & W & 0.28 & $\begin{array}{l}\text { It is cooked as a } \\
\text { mixture with other } \\
\text { types of an edible } \\
\text { herbs, and this is } \\
\text { called } \\
\text { (marshousheh). }\end{array}$ \\
\hline 162. & $\begin{array}{l}\text { Oryzopsis } \\
\text { miliacea L. } \\
\text { Asch.\& } \\
\text { Schweinf. }\end{array}$ & $\begin{array}{l}\text { Q } \\
\text { (Rezieh } \\
\text { naemeh) }\end{array}$ & Poaceae & W, R & 0.04 & $\begin{array}{l}\text { A decoction of grass } \\
\text { and roots is used as } \\
\text { diuretic. }\end{array}$ \\
\hline
\end{tabular}




\begin{tabular}{|c|c|c|c|c|c|c|}
\hline No. & $\begin{array}{l}\text { Name of } \\
\text { Species }\end{array}$ & $\begin{array}{l}\text { Common } \\
\text { Name (Arabic } \\
\text { Language) }\end{array}$ & Family & $\begin{array}{l}\text { Part } \\
\text { Used }\end{array}$ & MUV & Ethnobotanical Uses \\
\hline 163. & Osyris alba L. & प्रापा (Maknis) & Santalaceae & W & 0.025 & $\begin{array}{l}\text { A decoction of whole } \\
\text { plant is used rarely } \\
\text { for diarrhea and } \\
\text { dysentery. }\end{array}$ \\
\hline 164. & $\begin{array}{l}\text { Paliurus spina- } \\
\text { christi Mill. }\end{array}$ & 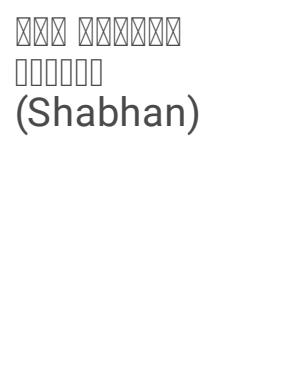 & Rhamnaceae & $\mathrm{F}$ & 0.007 & $\begin{array}{l}\text { A decoction of fruits } \\
\text { is used as anti- } \\
\text { rheumatic, diuretic, } \\
\text { and for diarrhea, and } \\
\text { used to lowering } \\
\text { cholesterol and } \\
\text { triglyceride levels in } \\
\text { the blood, and as } \\
\text { antihypertensive. }\end{array}$ \\
\hline 165. & $\begin{array}{l}\text { Papaver } \\
\text { rhoeas } \mathrm{L} .\end{array}$ & 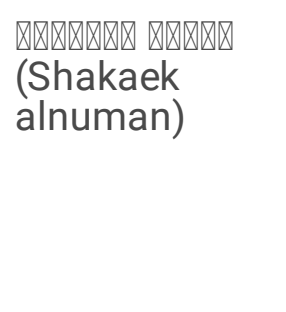 & Papaveraceae & $\mathrm{FI}$ & 0.407 & $\begin{array}{l}\text { A decoction of } \\
\text { flowers is used for } \\
\text { whooping cough, } \\
\text { headache, and has } \\
\text { hypnotic effect, } \\
\text { analgesic, as relieves } \\
\text { stress. }\end{array}$ \\
\hline 166. & $\begin{array}{l}\text { Paronychia } \\
\text { argentea Lam. }\end{array}$ & 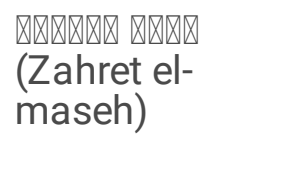 & Caryophyllaceae & $\mathrm{FI}$ & 0.64 & $\begin{array}{l}\text { An infusion of } \\
\text { flowers is used as } \\
\text { diuretic, and for } \\
\text { kidney stone. }\end{array}$ \\
\hline 167. & $\begin{array}{l}\text { Petroselinum } \\
\text { sativum } \\
\text { Hoffm. }\end{array}$ & 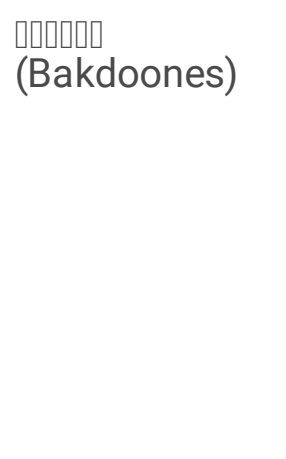 & Apiaceae & $\mathrm{FI}$ & 0.65 & $\begin{array}{l}\text { An infusion of } \\
\text { flowers is used for } \\
\text { anemia, and calms } \\
\text { nerves, and for } \\
\text { treating bruises, } \\
\text { insect bites and } \\
\text { rough skin, and anti- } \\
\text { toxic, it helps reduce } \\
\text { inflammation and } \\
\text { also helps cleanse } \\
\text { the liver. }\end{array}$ \\
\hline 168. & $\begin{array}{l}\text { Phaseolus } \\
\text { vulgaris L. }\end{array}$ & 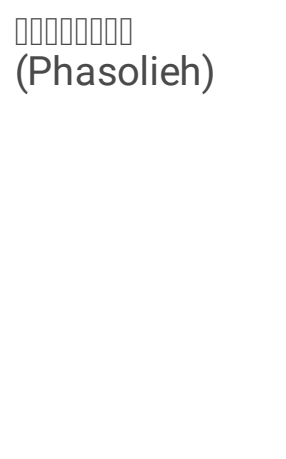 & Fabaceae & $\mathrm{F}, \mathrm{Bu}$ & 0.6 & $\begin{array}{l}\text { The fruits are boiled } \\
\text { and taken as a } \\
\text { diuretic and a } \\
\text { treatment for kidney } \\
\text { diseases, diabetes, } \\
\text { joint diseases and } \\
\text { rheumatism. Also, } \\
\text { grind the buds and } \\
\text { place them in the } \\
\text { form of dermal paste } \\
\text { on the affected area. }\end{array}$ \\
\hline
\end{tabular}




\begin{tabular}{|c|c|c|c|c|c|c|}
\hline No. & $\begin{array}{l}\text { Name of } \\
\text { Species }\end{array}$ & $\begin{array}{l}\text { Common } \\
\text { Name (Arabic } \\
\text { Language) }\end{array}$ & Family & $\begin{array}{l}\text { Part } \\
\text { Used }\end{array}$ & MUV & Ethnobotanical Uses \\
\hline 169. & $\begin{array}{l}\text { Phlomis } \\
\text { longifolia } \\
\text { Boiss. \& } \\
\text { Blanche }\end{array}$ & $\begin{array}{l}\text { A } \\
\text { (Laheeb) }\end{array}$ & Lamiaceae & Ap & 0.047 & $\begin{array}{l}\text { It is a bee plant and a } \\
\text { source of nectar and } \\
\text { pollen, and an } \\
\text { infusion of aerial } \\
\text { parts is used for } \\
\text { cases of rotting and } \\
\text { pus. }\end{array}$ \\
\hline 170. & $\begin{array}{l}\text { Phragmites } \\
\text { communis } \\
\text { Trin. }\end{array}$ & $\begin{array}{l}\text { R } \\
\text { (Kasab bari) }\end{array}$ & Poaceae & $S, R$ & 0.04 & $\begin{array}{l}\text { A decoction of stem } \\
\text { and root is used as } \\
\text { diuretic, also the } \\
\text { ashes of plants with } \\
\text { apple cider vinegar } \\
\text { are used in the } \\
\text { treatment of } \\
\text { alopecia. Peasants } \\
\text { sometimes using the } \\
\text { green parts of plant } \\
\text { after cutting it to } \\
\text { prepare organic } \\
\text { fertilizers. }\end{array}$ \\
\hline 171. & $\begin{array}{l}\text { Phillyrea media } \\
\text { L. }\end{array}$ & $\begin{array}{l}\text { U } \\
\text { (Zarwd) }\end{array}$ & Oleaceae & W & 0.014 & $\begin{array}{l}\text { An infusion of the } \\
\text { plant is used as a } \\
\text { diuretic, menstrual, } \\
\text { and mouthwash. }\end{array}$ \\
\hline 172. & $\begin{array}{l}\text { Pistacia } \\
\text { atlantica Desf. }\end{array}$ & प्रा (Batm) & Anacardiaceae & $F, G$ & 0.094 & $\begin{array}{l}\text { The fruits of the } \\
\text { mastic are called } \\
\text { green ivory in the } \\
\text { Syrian countryside, } \\
\text { fresh green fruits is } \\
\text { used in the treatment } \\
\text { of liver diseases, } \\
\text { tumors, joint } \\
\text { diseases, and for the } \\
\text { treatment of colds } \\
\text { and headaches, the } \\
\text { treatment of joint } \\
\text { pain, gum tree is } \\
\text { useful in treating } \\
\text { scabies, wounds and } \\
\text { fungal diseases, the } \\
\text { traditional Jarmashi } \\
\text { bread with the fruits } \\
\text { of the mastic, where } \\
\text { the green fruits give it } \\
\text { a delicious taste and } \\
\text { gives great energy } \\
\text { and vitality, Mastic } \\
\text { tree keeps poisonous } \\
\text { insects away. }\end{array}$ \\
\hline
\end{tabular}




\begin{tabular}{|c|c|c|c|c|c|c|}
\hline No. & $\begin{array}{l}\text { Name of } \\
\text { Species }\end{array}$ & $\begin{array}{l}\text { Common } \\
\text { Name (Arabic } \\
\text { Language) }\end{array}$ & Family & $\begin{array}{l}\text { Part } \\
\text { Used }\end{array}$ & MUV & Ethnobotanical Uses \\
\hline 173. & $\begin{array}{l}\text { Pinus brutia } \\
\text { Ten. }\end{array}$ & $\begin{array}{l}\text { (Sanobar bruti) } \\
\text { (Sanobar }\end{array}$ & Pinaceae & $\begin{array}{l}\text { Bk, } \\
\text { G, } \\
\text { Rs }\end{array}$ & 0.047 & $\begin{array}{l}\text { A decoction of the } \\
\text { bark is used topically } \\
\text { for wounds as a } \\
\text { soothing plaster. A } \\
\text { boiled extract of the } \\
\text { gum of Calabrian } \\
\text { pine is also used as a } \\
\text { pain reliever for } \\
\text { heumatism, and a } \\
\text { resin is used for } \\
\text { colds, constipation } \\
\text { and chronic } \\
\text { bronchitis. Externally, } \\
\text { the tar was } \\
\text { incorporated into an } \\
\text { ointment, or tar } \\
\text { shampoo, and } \\
\text { employed as a } \\
\text { remedy for such } \\
\text { chronic skin diseases } \\
\text { such as psoriasis and } \\
\text { eczema, and similar } \\
\text { skin problems, and is } \\
\text { used internally for } \\
\text { hemorrhoids, as an } \\
\text { astringent for } \\
\text { diarrhea, and for } \\
\text { cough remedies. }\end{array}$ \\
\hline
\end{tabular}




\begin{tabular}{|c|c|c|c|c|c|c|}
\hline No. & $\begin{array}{l}\text { Name of } \\
\text { Species }\end{array}$ & $\begin{array}{l}\text { Common } \\
\text { Name (Arabic } \\
\text { Language) }\end{array}$ & Family & $\begin{array}{l}\text { Part } \\
\text { Used }\end{array}$ & MUV & Ethnobotanical Uses \\
\hline 174. & $\begin{array}{l}\text { Pinus } \\
\text { halepensis } \\
\text { Mill. }\end{array}$ & 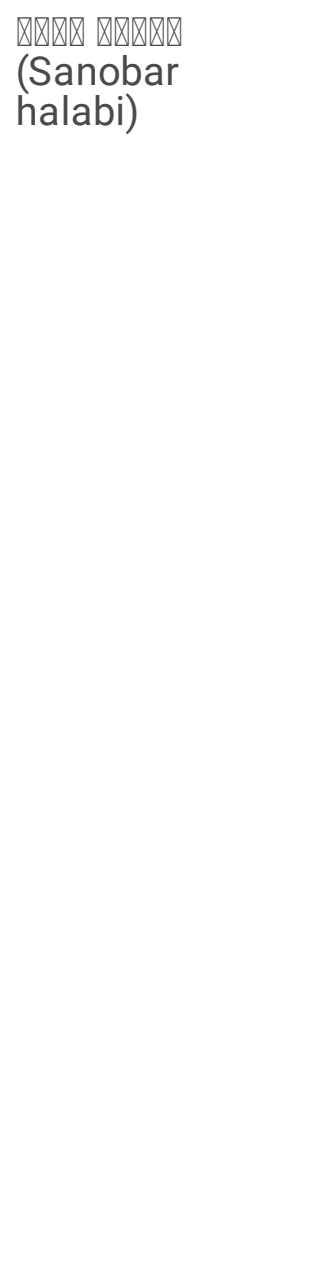 & Pinaceae & $\begin{array}{l}\mathrm{Bk}, \\
\mathrm{Bu}, \\
\mathrm{Sd}\end{array}$ & 0.229 & $\begin{array}{l}\text { The infusion of bark, } \\
\text { buds and needles is } \\
\text { used in the treatment } \\
\text { of kidney and bladder } \\
\text { diseases, } \\
\text { antihelminthic, } \\
\text { antiseptic and } \\
\text { diuretic. Treatment of } \\
\text { mucous membranes } \\
\text { and respiratory } \\
\text { diseases, such as: } \\
\text { colds, coughs, } \\
\text { tuberculosis, } \\
\text { influenza, bronchitis, } \\
\text { stuffy nose, and in } \\
\text { herbal baths as a } \\
\text { treatment for } \\
\text { rheumatic diseases, } \\
\text { and it is used in the } \\
\text { form of compresses, } \\
\text { and pine seed oil is } \\
\text { used in the treatment } \\
\text { of cold, cold and } \\
\text { rheumatism } \\
\text { symptoms, and is } \\
\text { useful For various } \\
\text { skin problems, such } \\
\text { as: wounds, burns, } \\
\text { boils, and sores, and } \\
\text { to relieve muscle and } \\
\text { nerve pain. }\end{array}$ \\
\hline 175. & $\begin{array}{l}\text { Pistacia } \\
\text { lentiscus L. }\end{array}$ & 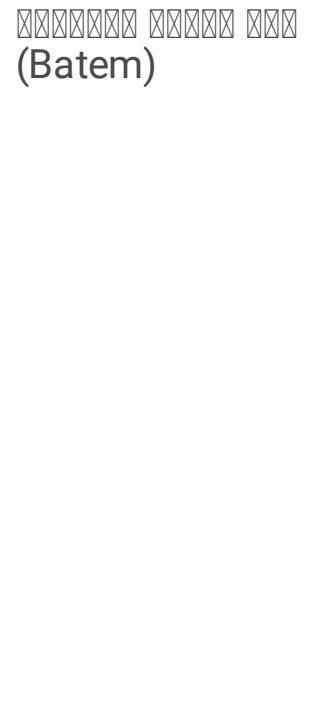 & Anacardiaceae & $L, G$ & 0.25 & $\begin{array}{l}\text { An infusion of leaves } \\
\text { is used internally to } \\
\text { treat respiratory } \\
\text { problems such as: } \\
\text { sore throat, } \\
\text { bronchitis, allergies, } \\
\text { and asthma, stomach } \\
\text { ulcers, and the mastic } \\
\text { gum is used to relief } \\
\text { throat sore and } \\
\text { stomach aches, } \\
\text { diabetes, jaundice } \\
\text { and gastrointestinal } \\
\text { disorders, and } \\
\text { topically is used for } \\
\text { wounds and burns } \\
\text { healing, } \\
\text { haemorrhoids. }\end{array}$ \\
\hline
\end{tabular}




\begin{tabular}{|c|c|c|c|c|c|c|}
\hline No. & $\begin{array}{l}\text { Name of } \\
\text { Species }\end{array}$ & $\begin{array}{l}\text { Common } \\
\text { Name (Arabic } \\
\text { Language) }\end{array}$ & Family & $\begin{array}{l}\text { Part } \\
\text { Used }\end{array}$ & MUV & Ethnobotanical Uses \\
\hline 176. & $\begin{array}{l}\text { Pisum elatius } \\
\text { M.Bieb. }\end{array}$ & 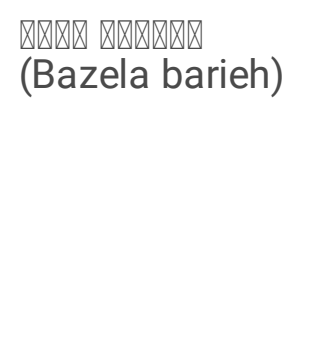 & Fabaceae & $\mathrm{P}, \mathrm{Sd}$ & 0.214 & $\begin{array}{l}\text { A decoction of pods } \\
\text { is used for diabetes, } \\
\text { digestion tonic, } \\
\text { irritable bowel (IBS), } \\
\text { lipid-lowering, and the } \\
\text { seed powder is used } \\
\text { to treat some skin } \\
\text { diseases topically. }\end{array}$ \\
\hline 177. & $\begin{array}{l}\text { Plantago } \\
\text { lanceolata L. }\end{array}$ & 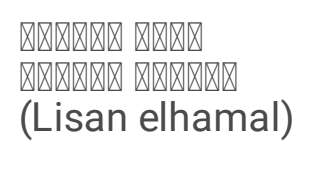 & Plantaginaceae & $\mathrm{L}, \mathrm{Sd}$ & 0.167 & $\begin{array}{l}\text { An infusion of leaves } \\
\text { and seeds is used as } \\
\text { expectorant, and } \\
\text { slimming. }\end{array}$ \\
\hline 178. & $\begin{array}{l}\text { Platanus } \\
\text { orientalis L. }\end{array}$ & प्र (Delb) & Platanaceae & $\mathrm{Ph}$ & 0.112 & $\begin{array}{l}\text { The phloem is used } \\
\text { as phlegm remover. }\end{array}$ \\
\hline 179. & $\begin{array}{l}\text { Plumbago } \\
\text { europaea } \mathrm{L} \text {. }\end{array}$ & 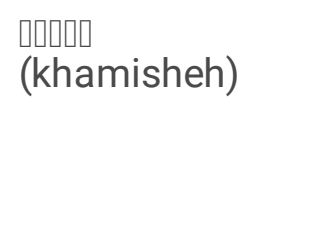 & Plumbaginaceae & $\mathrm{FI}$ & 0.01 & $\begin{array}{l}\text { An infusion of } \\
\text { flowers is used } \\
\text { topically for treating } \\
\text { alopecia and } \\
\text { psoriasis. }\end{array}$ \\
\hline 180. & $\begin{array}{l}\text { Portulaca } \\
\text { oleracea L. }\end{array}$ & स्सा (bakleh) & Portulacaceae & $\mathrm{W}, \mathrm{FI}$ & 0.614 & $\begin{array}{l}\text { A fresh herb is used } \\
\text { as tonic and laxative. } \\
\text { An infusion of } \\
\text { flowering herbs is } \\
\text { used for kidney } \\
\text { disorders and } \\
\text { improve digestion, } \\
\text { prevention of heart } \\
\text { disease and cancer, } \\
\text { and for weight } \\
\text { reduction, stomach } \\
\text { diseases, and bone } \\
\text { strengthening. }\end{array}$ \\
\hline 181. & $\begin{array}{l}\text { Polygala } \\
\text { supina Schreb. }\end{array}$ & 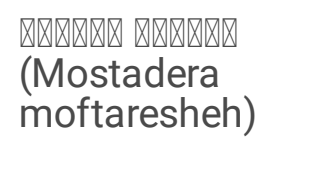 & Polygalaceae & W & 0.018 & $\begin{array}{l}\text { A decoction of whole } \\
\text { plant is used as an } \\
\text { anthelmintic and } \\
\text { expectorant. }\end{array}$ \\
\hline 182. & $\begin{array}{l}\text { Polygala } \\
\text { amara L. }\end{array}$ & 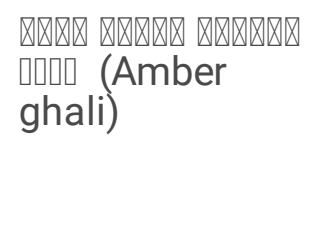 & Polygalaceae & $\mathrm{FI}$ & 0.007 & $\begin{array}{l}\text { An infusion of } \\
\text { flowering herb is used } \\
\text { as diuretic, tonic, } \\
\text { digestive, and } \\
\text { expectorant. }\end{array}$ \\
\hline 183. & $\begin{array}{l}\text { Polygonum } \\
\text { maritimum L. }\end{array}$ & 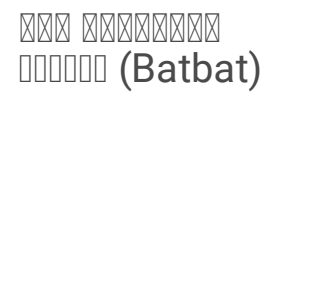 & Polygonaceae & $\mathrm{FI}$ & 0.065 & $\begin{array}{l}\text { A decoction of } \\
\text { flowering herb is used } \\
\text { as analgesic, } \\
\text { antiseptic, astringent, } \\
\text { bile tonic, laxative, } \\
\text { diuretic, tonic, } \\
\text { anthelmintic. }\end{array}$ \\
\hline
\end{tabular}




\begin{tabular}{|c|c|c|c|c|c|c|}
\hline No. & $\begin{array}{l}\text { Name of } \\
\text { Species }\end{array}$ & $\begin{array}{l}\text { Common } \\
\text { Name (Arabic } \\
\text { Language) }\end{array}$ & Family & $\begin{array}{l}\text { Part } \\
\text { Used }\end{array}$ & MUV & Ethnobotanical Uses \\
\hline 184. & $\begin{array}{l}\text { Populus nigra } \\
\text { L. }\end{array}$ & 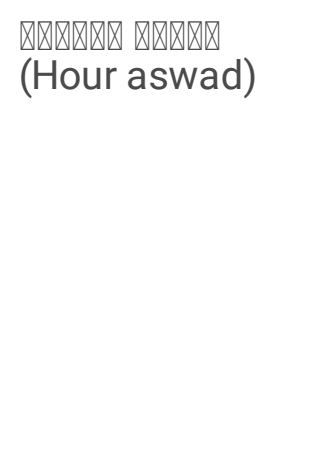 & Salicaceae & $\begin{array}{l}\mathrm{Bk} \\
\mathrm{Bu}\end{array}$ & 0.17 & $\begin{array}{l}\text { An infusion of bark } \\
\text { and buds is used for } \\
\text { fever, gout, kidney } \\
\text { disease, prostatic } \\
\text { hypertrophy, } \\
\text { prostatitis, colds, } \\
\text { influenza, toothache } \\
\text { also it is used } \\
\text { topically for burns, } \\
\text { hemorrhoids, and } \\
\text { rheumatism. }\end{array}$ \\
\hline 185. & $\begin{array}{l}\text { Poterium } \\
\text { spinosum } \mathrm{L} .\end{array}$ & प्राप्रा (Ballan) & Rosaceae & $\mathrm{R}$ & 0.174 & $\begin{array}{l}\text { A decoction of roots } \\
\text { is used internally as } \\
\text { expectorant, } \\
\text { digestive, diuretic, } \\
\text { anti-diarrhea, and for } \\
\text { diabetics, while a } \\
\text { decoction of aerial } \\
\text { parts is used topically } \\
\text { for hemorrhoids. }\end{array}$ \\
\hline 186. & $\begin{array}{l}\text { Primula } \\
\text { vulgaris Huds. }\end{array}$ & 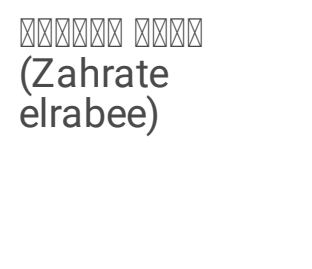 & Primulaceae & $\mathrm{Fl}, \mathrm{R}$ & 0.069 & $\begin{array}{l}\text { An infusion of } \\
\text { flowers and roots } \\
\text { internally is used as } \\
\text { expectorant, and } \\
\text { externally it is used } \\
\text { for eczema. }\end{array}$ \\
\hline 187. & $\begin{array}{l}\text { Prunella } \\
\text { orientalis } \\
\text { Bornm. }\end{array}$ & 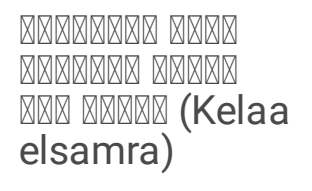 & Lamiaceae & Ap & 0.094 & $\begin{array}{l}\text { An infusion of aerial } \\
\text { parts is used } \\
\text { internally for } \\
\text { hypertension. }\end{array}$ \\
\hline 188. & $\begin{array}{l}\text { Prunus avium } \\
\text { (L.) L. }\end{array}$ & प्रा (Karaz) & Rosaceae & $S, F$ & 0.425 & $\begin{array}{l}\text { Cherry stalk infusion } \\
\text { is used as a sedative, } \\
\text { helps in losing } \\
\text { weight, is good for } \\
\text { the liver, and is a } \\
\text { diuretic in for kidney } \\
\text { stone. The fruits are } \\
\text { nutritious and useful } \\
\text { for diseases of the } \\
\text { respiratory tract } \\
\text { infections. }\end{array}$ \\
\hline 189. & $\begin{array}{l}\text { Prunus } \\
\text { divaricata } \\
\text { Ledeb. }\end{array}$ & प्राप्(Janerek) & Rosaceae & $\mathrm{F}$ & 0.272 & $\begin{array}{l}\text { Cherry plum fruits are } \\
\text { used as an appetite } \\
\text { suppressant, as it } \\
\text { helps in the digestion } \\
\text { of food, and to } \\
\text { prevent kidney } \\
\text { disease, and to } \\
\text { control blood } \\
\text { pressure. }\end{array}$ \\
\hline
\end{tabular}




\begin{tabular}{|c|c|c|c|c|c|c|}
\hline No. & $\begin{array}{l}\text { Name of } \\
\text { Species }\end{array}$ & $\begin{array}{l}\text { Common } \\
\text { Name (Arabic } \\
\text { Language) }\end{array}$ & Family & $\begin{array}{l}\text { Part } \\
\text { Used }\end{array}$ & MUV & Ethnobotanical Uses \\
\hline 190. & $\begin{array}{l}\text { Prunus } \\
\text { mahaleb L. }\end{array}$ & प्राप (Mahlab) & Rosaceae & $\mathrm{F}$ & 0.069 & $\begin{array}{l}\text { The mahlab cherry is } \\
\text { used in the } \\
\text { manufacture of } \\
\text { "pastries" and } \\
\text { "sweets", and the } \\
\text { decoction of the } \\
\text { necks of the cherries } \\
\text { of the mahleb is used } \\
\text { in the treatment of } \\
\text { kidney diseases. }\end{array}$ \\
\hline 191. & $\begin{array}{l}\text { Prunus persica } \\
\text { (L.) Batsch. }\end{array}$ & प्रा (Doraak) & Rosaceae & $\mathrm{F}$ & 0.305 & $\begin{array}{l}\text { Fruits juice is used } \\
\text { for digestive } \\
\text { disorders, helps fight } \\
\text { constipation, kidney } \\
\text { disease, and } \\
\text { rheumatism. }\end{array}$ \\
\hline 192. & $\begin{array}{l}\text { Psoralea } \\
\text { bituminosa L. }\end{array}$ & 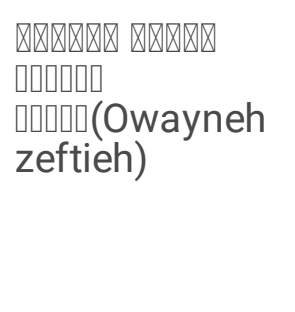 & Fabaceae & $\mathrm{Fl}, \mathrm{L}$ & 0.025 & $\begin{array}{l}\text { An infusion of } \\
\text { flowers and leaves is } \\
\text { used externally to } \\
\text { treat some skin } \\
\text { diseases such as } \\
\text { psoriasis, vitiligo, and } \\
\text { skin ulcers. }\end{array}$ \\
\hline 193. & $\begin{array}{l}\text { Pteridium } \\
\text { aquilinum (L.) } \\
\text { Kuhn }\end{array}$ & 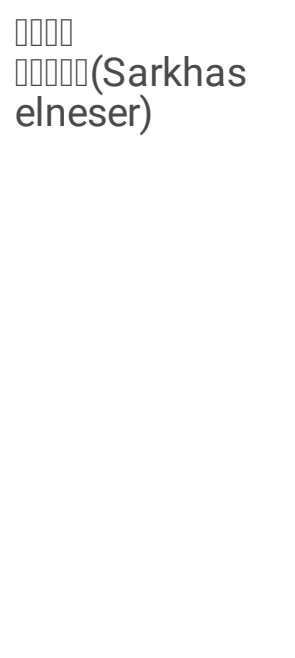 & Pteridaceae & $\mathrm{R}, \mathrm{L}$ & 0.21 & $\begin{array}{l}\text { A decoction of root is } \\
\text { useful in treating } \\
\text { varicose veins and } \\
\text { chronic headaches, } \\
\text { also is used as } \\
\text { laxative and } \\
\text { anthelmintic, the } \\
\text { crushed leaves are } \\
\text { applied to pain, the } \\
\text { sufferer in this case } \\
\text { will feel severe pain, } \\
\text { but it will end after a } \\
\text { short time, it is used } \\
\text { for back pain, } \\
\text { rheumatism, arthritis, } \\
\text { gout. }\end{array}$ \\
\hline 194. & $\begin{array}{l}\text { Punica } \\
\text { granatum L. }\end{array}$ & प्राप्र (Rumman) & Punicaceae & $\mathrm{F}, \mathrm{Bk}$ & 0.454 & $\begin{array}{l}\text { The fruit juice is used } \\
\text { for mouth sores, } \\
\text { cough, malabsorption } \\
\text { syndrome, } \\
\text { hypercholesterolemia, } \\
\text { the bark is used as } \\
\text { anthelmintic, and for } \\
\text { diarrhea, amebic } \\
\text { dysentery, } \\
\text { antibacterial, ulcer. }\end{array}$ \\
\hline
\end{tabular}




\begin{tabular}{|c|c|c|c|c|c|c|}
\hline No. & $\begin{array}{l}\text { Name of } \\
\text { Species }\end{array}$ & $\begin{array}{l}\text { Common } \\
\text { Name (Arabic } \\
\text { Language) }\end{array}$ & Family & $\begin{array}{l}\text { Part } \\
\text { Used }\end{array}$ & MUV & Ethnobotanical Uses \\
\hline 195. & $\begin{array}{l}\text { Pyrus syriaca } \\
\text { Boiss. }\end{array}$ & 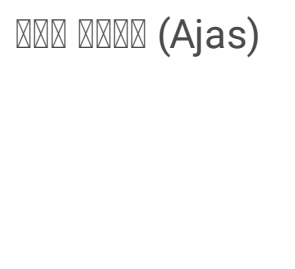 & Rosaceae & $\mathrm{F}$ & 0.101 & $\begin{array}{l}\text { Fresh fruit is used to } \\
\text { improve digestion, } \\
\text { and to lose weight, } \\
\text { while its syrup is } \\
\text { used as a diuretic } \\
\text { and laxative. }\end{array}$ \\
\hline 196. & $\begin{array}{l}\text { Quercus } \\
\text { calliprinos } \\
\text { Webb }\end{array}$ & 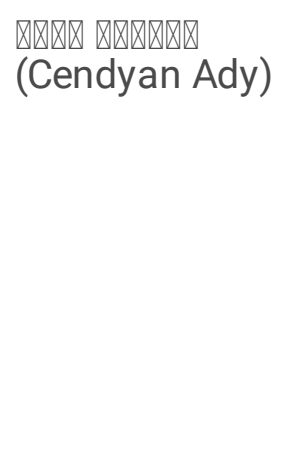 & Fagaceae & Bk & 0.083 & $\begin{array}{l}\text { A decoction of bark is } \\
\text { used as antiseptics } \\
\text { and to treat } \\
\text { gastrointestinal tract } \\
\text { (GIT) disorders such } \\
\text { as chronic diarrhea, } \\
\text { dysentery, and } \\
\text { jaundice. It is used } \\
\text { topically for } \\
\text { hemorrhoids and } \\
\text { wound healing. }\end{array}$ \\
\hline 197. & $\begin{array}{l}\text { Quercus } \\
\text { infectoria } \\
\text { G.Olivier }\end{array}$ & प्रा (Ballot) & Fagaceae & $\mathrm{F}, \mathrm{Bk}$ & 0.105 & $\begin{array}{l}\text { A decoction of fruits } \\
\text { and bark is used as } \\
\text { anti-bleeding and } \\
\text { pain reliever, and } \\
\text { helps in digestion, } \\
\text { blood purification, } \\
\text { coughing, and } \\
\text { topically is used for } \\
\text { eczema treatment. }\end{array}$ \\
\hline 198. & $\begin{array}{l}\text { Quercus } \\
\text { ithaburensis } \\
\text { Decne. }\end{array}$ & $\begin{array}{l}\text { प्राप्रा } \\
\text { (Cendyan) }\end{array}$ & Fagaceae & $\begin{array}{l}S_{1} \\
B k, F\end{array}$ & 0.13 & $\begin{array}{l}\text { A decoction of stem } \\
\text { and bark and fruit is } \\
\text { used for cancer, fever, } \\
\text { bed wetting, high } \\
\text { blood pressure and } \\
\text { ulcer. }\end{array}$ \\
\hline 199. & $\begin{array}{l}\text { Raphanus } \\
\text { raphanistrum } \\
\text { L. }\end{array}$ & 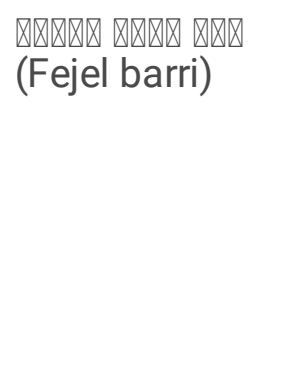 & Cruciferae & $\begin{array}{l}\mathrm{R}, \mathrm{L}, \\
\mathrm{S}\end{array}$ & 0.516 & $\begin{array}{l}\text { A decoction of roots } \\
\text { is used as diuretic, } \\
\text { anti-cancer, and for } \\
\text { rheumatism, and the } \\
\text { dried roots is used for } \\
\text { liver diseases, a } \\
\text { decoction of leaves } \\
\text { and stems as } \\
\text { diuretic. }\end{array}$ \\
\hline 200. & $\begin{array}{l}\text { Rhamnus } \\
\text { alaternus } \mathrm{L} \text {. }\end{array}$ & स्व (Nabak) & Rhamnaceae & $\mathrm{L}$ & 0.123 & $\begin{array}{l}\text { A decoction of leaves } \\
\text { is used as a diuretic, } \\
\text { laxative, hypotensive } \\
\text { drug and for the } \\
\text { treatment of } \\
\text { diabetes. }\end{array}$ \\
\hline
\end{tabular}




\begin{tabular}{|c|c|c|c|c|c|c|}
\hline No. & $\begin{array}{l}\text { Name of } \\
\text { Species }\end{array}$ & $\begin{array}{l}\text { Common } \\
\text { Name (Arabic } \\
\text { Language) }\end{array}$ & Family & $\begin{array}{l}\text { Part } \\
\text { Used }\end{array}$ & MUV & Ethnobotanical Uses \\
\hline 201. & $\begin{array}{l}\text { Rhus coriaria } \\
\text { L. }\end{array}$ & प्रा (Sumac) & Anacardiacea & $\mathrm{F}$ & 0.338 & $\begin{array}{l}\text { A decoction of fruits } \\
\text { is used internally for } \\
\text { respiratory tract } \\
\text { infection, and } \\
\text { coughing, colds and } \\
\text { influenza, bronchitis, } \\
\text { and is used for } \\
\text { digestive disorders, } \\
\text { constipation and } \\
\text { stomach disorders, } \\
\text { while a gargling is } \\
\text { used for sore throat } \\
\text { and mouth. A boiled } \\
\text { sumac peel is used to } \\
\text { treat skin fungus, } \\
\text { burns and skin ulcers. }\end{array}$ \\
\hline 202. & Rhus cotinus $\mathrm{L}$. & प्राप्र (Bakas) & Anacardiacea & W & 0.098 & $\begin{array}{l}\text { A decoction of herb is } \\
\text { used to prepare an } \\
\text { herbal tea for } \\
\text { treatment of diarrhea, } \\
\text { mouth inflammation } \\
\text { and gastric and } \\
\text { peptic ulcers, also it } \\
\text { is used as antiseptic, } \\
\text { anti-inflammatory } \\
\text { while topically it is } \\
\text { used for hair loss, leg } \\
\text { sweating and wound- } \\
\text { healing. }\end{array}$ \\
\hline 203. & $\begin{array}{l}\text { Rhus tripartita } \\
\text { (Ucria) Grande }\end{array}$ & प्राप्र (Aryneh) & Anacardiacea & W & 0.05 & $\begin{array}{l}\text { A decoction of whole } \\
\text { plant is used as } \\
\text { diuretic, and for } \\
\text { kidney stone. }\end{array}$ \\
\hline 204. & $\begin{array}{l}\text { Rosmarinus } \\
\text { officinalis } \mathrm{L} \text {. }\end{array}$ & 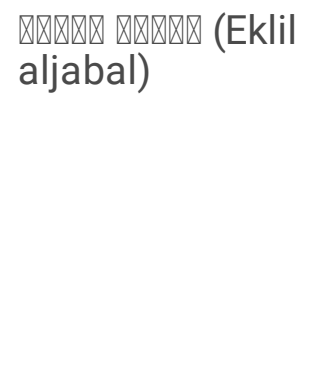 & Lamiaceae & L & 0.901 & $\begin{array}{l}\text { An infusion of leaves } \\
\text { is used respiratory } \\
\text { diseases, heart } \\
\text { disorders, to enhance } \\
\text { memory, enhance the } \\
\text { body's immunity, treat } \\
\text { headache, } \\
\text { antidepressant, and } \\
\text { tonic. }\end{array}$ \\
\hline 205. & $\begin{array}{l}\text { Rubia aucheri } \\
\text { Boiss. }\end{array}$ & स्साप्र (Robia) & Rubiaceae & $\mathrm{R}$ & 0.047 & $\begin{array}{l}\text { A decoction of roots } \\
\text { is used internally for } \\
\text { kidney and bladder } \\
\text { stones, and topically } \\
\text { for strengthening of } \\
\text { hair. }\end{array}$ \\
\hline
\end{tabular}




\begin{tabular}{|c|c|c|c|c|c|c|}
\hline No. & $\begin{array}{l}\text { Name of } \\
\text { Species }\end{array}$ & $\begin{array}{l}\text { Common } \\
\text { Name (Arabic } \\
\text { Language) }\end{array}$ & Family & $\begin{array}{l}\text { Part } \\
\text { Used }\end{array}$ & MUV & Ethnobotanical Uses \\
\hline 206. & $\begin{array}{l}\text { Rubus } \\
\text { fruticosus } \\
\text { G.N.Jones }\end{array}$ & 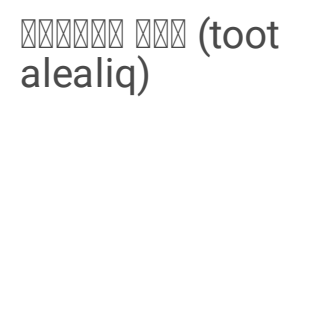 & Rosaceae & $F, R$ & 0.047 & $\begin{array}{l}\text { An infusion of fruits } \\
\text { and root is used for } \\
\text { kidney stone, } \\
\text { glycemic, } \\
\text { atherosclerosis, } \\
\text { hypotensive, and } \\
\text { anticoagulant. }\end{array}$ \\
\hline 207. & $\begin{array}{l}\text { Rubus sanctus } \\
\text { Schreb. }\end{array}$ & 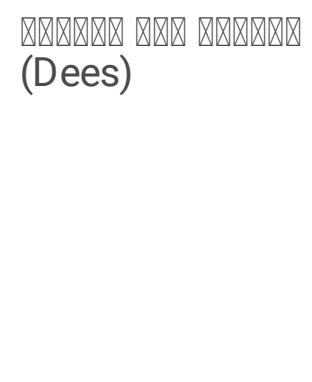 & Rosaceae & $\mathrm{F}, \mathrm{L}$ & 0.323 & $\begin{array}{l}\text { An infusion of fruits } \\
\text { is used as diuretic } \\
\text { and laxative and } \\
\text { general tonic. A } \\
\text { decoction of leaf is } \\
\text { used for disorders of } \\
\text { the gastrointestinal } \\
\text { tract, the respiratory } \\
\text { tract. }\end{array}$ \\
\hline 208. & $\begin{array}{l}\text { Rumex } \\
\text { conglomeratus } \\
\text { Murray }\end{array}$ & प्राप (Hamad) & Polygonaceae & $\begin{array}{l}\text { Ap, } \\
\mathrm{R}\end{array}$ & 0.08 & $\begin{array}{l}\text { An infusion of aerial } \\
\text { parts and roots of the } \\
\text { plants are used as } \\
\text { diuretic and improve } \\
\text { digestion, analgesic, } \\
\text { coughs of all kinds, } \\
\text { colds and bronchitis. }\end{array}$ \\
\hline 209. & $\begin{array}{l}\text { Rumex } \\
\text { obtusifolius L. }\end{array}$ & 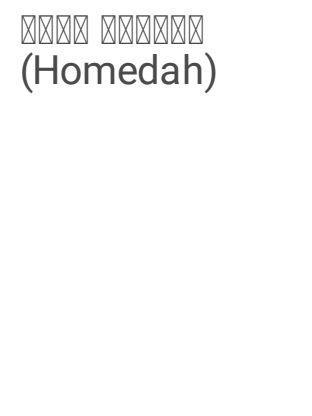 & Polygonaceae & L & 0.05 & $\begin{array}{l}\text { An infusion of leaves } \\
\text { is used for mouth } \\
\text { ulcers, for anemia, } \\
\text { adjust sugar, improve } \\
\text { blood circulation, the } \\
\text { cooked leaves are } \\
\text { edible as special } \\
\text { traditional Syrian } \\
\text { recipe known as } \\
\text { Syrian saleeg. }\end{array}$ \\
\hline 210. & $\begin{array}{l}\text { Ruscus } \\
\text { aculeatus } \mathrm{L} .\end{array}$ & 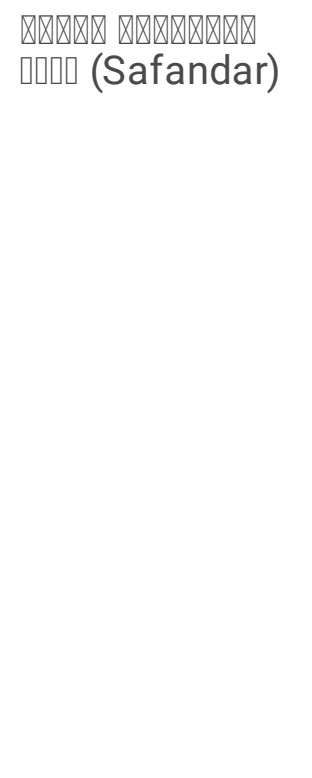 & Alliaceae & L & 0.014 & $\begin{array}{l}\text { A decoction of leaves } \\
\text { and fruit peels are } \\
\text { astringent, and for } \\
\text { menstruation, } \\
\text { hepatitis, colon } \\
\text { disorders, venous } \\
\text { insufficiency, } \\
\text { hemorrhoids, } \\
\text { asthma, uterine } \\
\text { infections, and a } \\
\text { diuretic for cases of } \\
\text { urinary system } \\
\text { infections, and is also } \\
\text { used in the treatment } \\
\text { of jaundice, and } \\
\text { urinary tract stones, } \\
\text { also it is used to heal } \\
\text { broken bones, and } \\
\text { twisted joints. }\end{array}$ \\
\hline
\end{tabular}




\begin{tabular}{|c|c|c|c|c|c|c|}
\hline No. & $\begin{array}{l}\text { Name of } \\
\text { Species }\end{array}$ & $\begin{array}{l}\text { Common } \\
\text { Name (Arabic } \\
\text { Language) }\end{array}$ & Family & $\begin{array}{l}\text { Part } \\
\text { Used }\end{array}$ & MUV & Ethnobotanical Uses \\
\hline 211. & Salix alba L. & 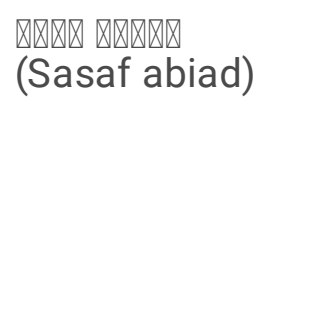 & Salicaceae & $\mathrm{L}, \mathrm{Pe}$ & 0.087 & $\begin{array}{l}\text { A decoction of leaves } \\
\text { and peels are used } \\
\text { for intermittent } \\
\text { fevers, arthritis, gout, } \\
\text { bladder infections } \\
\text { and high } \\
\text { temperature. }\end{array}$ \\
\hline 212. & $\begin{array}{l}\text { Salvia } \\
\text { aramiensis } \\
\text { Rech.f. }\end{array}$ & $\begin{array}{l}\text { (Meiramiea) } \\
\text { (Mend }\end{array}$ & Lamiaceae & $L, R$ & 0.847 & $\begin{array}{l}\text { An infusion of leaves } \\
\text { is used for stomach } \\
\text { and colon disorders, } \\
\text { regulator and } \\
\text { sterilizer for uterine } \\
\text { diseases in women, } \\
\text { intestinal antiseptic, } \\
\text { diuretic, a decoction } \\
\text { of roots is used for } \\
\text { treating diabetes. }\end{array}$ \\
\hline 213. & $\begin{array}{l}\text { Sambucus } \\
\text { ebulus L. }\end{array}$ & 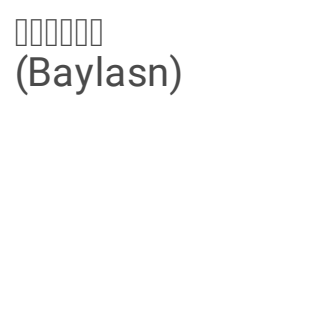 & Caprifoliaceae & $\begin{array}{l}\mathrm{Fl} \\
\mathrm{Sd}\end{array}$ & 0.24 & $\begin{array}{l}\text { An infusion of } \\
\text { flowers and seeds is } \\
\text { used in the treatment } \\
\text { of diabetes, } \\
\text { constipation, } \\
\text { abdominal gas, cold } \\
\text { and flu symptoms. }\end{array}$ \\
\hline 214. & $\begin{array}{l}\text { Sarcopoterium } \\
\text { spinosum L. } \\
\text { Spach }\end{array}$ & 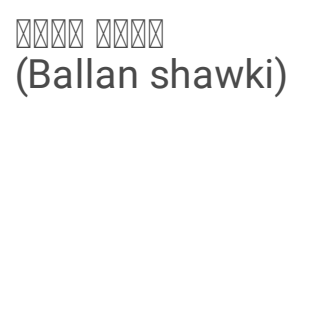 & Rosaceae & $\begin{array}{l}\mathrm{R} \\
\mathrm{Sd}\end{array}$ & 0.265 & $\begin{array}{l}\text { A decoction of roots } \\
\text { is used topically for } \\
\text { treating joints and } \\
\text { spinal disc, a } \\
\text { decoction of seeds } \\
\text { for hemorrhoids, } \\
\text { diabetes. }\end{array}$ \\
\hline 215. & $\begin{array}{l}\text { Saponaria } \\
\text { officinalis } \mathrm{L} \text {. }\end{array}$ & 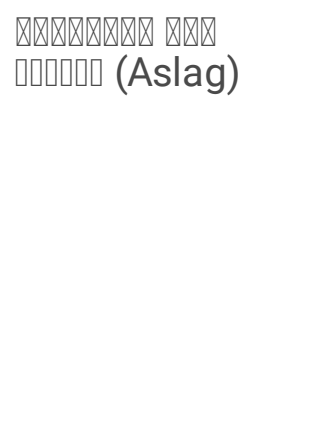 & Caryophyllaceae & $\mathrm{R}$ & 0.28 & $\begin{array}{l}\text { A decoction of roots } \\
\text { is used for getting rid } \\
\text { of phlegm and } \\
\text { relieving congestion } \\
\text { of the respiratory } \\
\text { system, for cases of } \\
\text { gout and arthritis, } \\
\text { and it is used in } \\
\text { cases of } \\
\text { constipation. }\end{array}$ \\
\hline 216. & $\begin{array}{l}\text { Sarothamnus } \\
\text { scoparius (L.) } \\
\text { W.D.J.Koch }\end{array}$ & प्रा (Wazal) & Fabaceae & $\begin{array}{l}\mathrm{Fl}, \\
\mathrm{Sd}, \\
\mathrm{Br}\end{array}$ & 0.047 & $\begin{array}{l}\text { A decoction of } \\
\text { flowers and seeds } \\
\text { and soft branches is } \\
\text { used to treat urinary } \\
\text { disorders. }\end{array}$ \\
\hline 217. & $\begin{array}{l}\text { Scabiosa } \\
\text { syriaca L. }\end{array}$ & 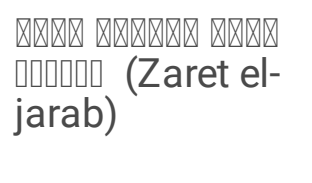 & Dipsacaceae & Ap & 0.029 & $\begin{array}{l}\text { The juice of aerial } \\
\text { parts is used for } \\
\text { treatment of scabies } \\
\text { topically. }\end{array}$ \\
\hline
\end{tabular}




\begin{tabular}{|c|c|c|c|c|c|c|}
\hline No. & $\begin{array}{l}\text { Name of } \\
\text { Species }\end{array}$ & $\begin{array}{l}\text { Common } \\
\text { Name (Arabic } \\
\text { Language) }\end{array}$ & Family & $\begin{array}{l}\text { Part } \\
\text { Used }\end{array}$ & MUV & Ethnobotanical Uses \\
\hline 218. & $\begin{array}{l}\text { Scandix } \\
\text { pecten-veneris } \\
\text { L. }\end{array}$ & 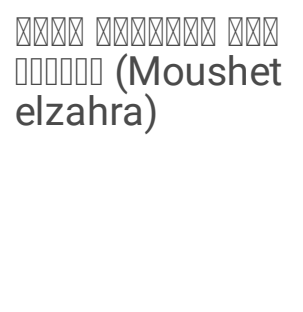 & Apiaceae & Ap & 0.025 & $\begin{array}{l}\text { A wild green leafy is } \\
\text { edible and it is used } \\
\text { in the Mediterranean } \\
\text { diet, which are either } \\
\text { consumed boiled by } \\
\text { just adding Syrian } \\
\text { olive oil, or in pies. }\end{array}$ \\
\hline 219. & $\begin{array}{l}\text { Scutellaria } \\
\text { baicalensis } \\
\text { Georgi. }\end{array}$ & प्रा (Darka) & Lamiaceae & $\begin{array}{l}\mathrm{Ap} \\
\mathrm{R}\end{array}$ & 0.021 & $\begin{array}{l}\text { A decoction of aerial } \\
\text { parts and roots as } \\
\text { diuretic, also is used } \\
\text { for asthma, mental } \\
\text { and nervous distress, } \\
\text { insomnia, epilepsy, } \\
\text { dysmenorrhea. }\end{array}$ \\
\hline 220. & $\begin{array}{l}\text { Securigera } \\
\text { securidaca }(\mathrm{L} .) \\
\text { Degen \& Dorfl }\end{array}$ & प्राप्र (Sobaira) & Fabaceae & Sd & 0.567 & $\begin{array}{l}\text { A decoction of seeds } \\
\text { is used for diabetes, } \\
\text { hyperlipidemia, high } \\
\text { blood pressure, } \\
\text { gastric reflux, and } \\
\text { externally it is used } \\
\text { for wound healing. }\end{array}$ \\
\hline 221. & $\begin{array}{l}\text { Setaria viridis } \\
\text { (L.) P.Beauv. }\end{array}$ & प्रापार (Lezeek) & Poaceae & $\begin{array}{l}\text { L, S, } \\
\text { W, } \\
\text { Sd }\end{array}$ & 0.076 & $\begin{array}{l}\text { A decoction of leaves } \\
\text { and stems for } \\
\text { stimulating digestion, } \\
\text { The plant is crushed } \\
\text { and mixed with water } \\
\text { then used as an } \\
\text { external application } \\
\text { in the treatment of } \\
\text { psoriasis, bruises, } \\
\text { various wounds, } \\
\text { cutaneous eczema, } \\
\text { vaginal gonorrhea. } \\
\text { While the seed is } \\
\text { used as diuretic, } \\
\text { febrifuge, refrigerant } \\
\text { and tonic, to treat } \\
\text { intestinal infection } \\
\text { with parasites and } \\
\text { worms, jaundice, and } \\
\text { to reduce swelling of } \\
\text { the legs and feet in } \\
\text { patients with urinary } \\
\text { tract diseases, } \\
\text { swollen lymph nodes, } \\
\text { and help in cases of } \\
\text { cystitis. }\end{array}$ \\
\hline
\end{tabular}




\begin{tabular}{|c|c|c|c|c|c|c|}
\hline No. & $\begin{array}{l}\text { Name of } \\
\text { Species }\end{array}$ & $\begin{array}{l}\text { Common } \\
\text { Name (Arabic } \\
\text { Language) }\end{array}$ & Family & $\begin{array}{l}\text { Part } \\
\text { Used }\end{array}$ & MUV & Ethnobotanical Uses \\
\hline 222. & $\begin{array}{l}\text { Silybum } \\
\text { marianum (L.) } \\
\text { Gaertn. }\end{array}$ & 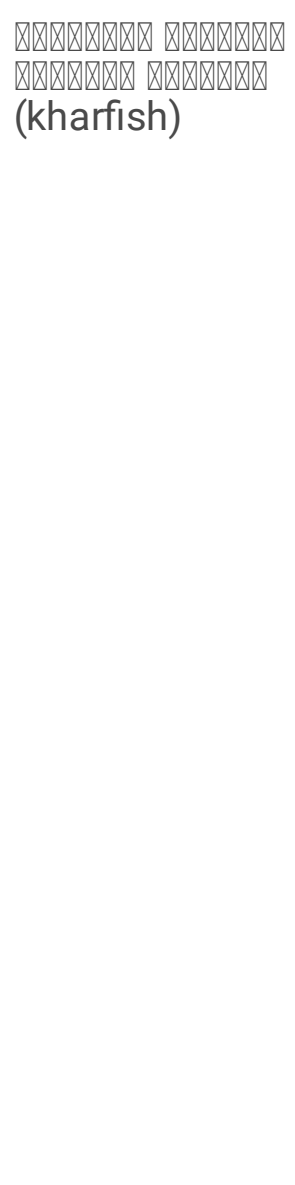 & Asteraceae & Sd & 0.683 & $\begin{array}{l}\text { A decoction of seeds } \\
\text { is used to treat } \\
\text { Crohn's disease, } \\
\text { ulcerative colitis, and } \\
\text { inflammation of the } \\
\text { gastrointestinal tract, } \\
\text { and is used as an } \\
\text { immune system } \\
\text { booster, to prevent } \\
\text { cancer, and to treat } \\
\text { liver diseases and } \\
\text { liver infections, } \\
\text { cleanse the liver from } \\
\text { accumulated toxins, } \\
\text { contribute to the } \\
\text { production of } \\
\text { breastfeeding milk, } \\
\text { treat a lack of } \\
\text { appetite and } \\
\text { indigestion, } \\
\text { dyspepsia, } \\
\text { aphrodisiac for } \\
\text { women and men, and } \\
\text { diabetics, varicose } \\
\text { veins, for the } \\
\text { treatment of } \\
\text { congestion of the } \\
\text { uterus and uterine } \\
\text { infections. }\end{array}$ \\
\hline 223. & $\begin{array}{l}\text { Smilax aspera } \\
\text { L. }\end{array}$ & 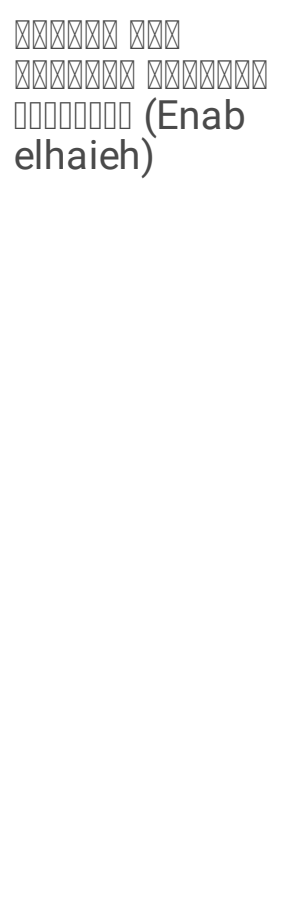 & Smilacaceae & $\mathrm{R}$ & 0.047 & $\begin{array}{l}\text { Root powder used as } \\
\text { a male aphrodisiac } \\
\text { and increases fertility, } \\
\text { and for arthritis and } \\
\text { gout, flatulence and } \\
\text { carminative, chronic } \\
\text { neuropathy, and for } \\
\text { cough and colds, } \\
\text { fatigue, muscle pain } \\
\text { and weakness, useful } \\
\text { as treatment for low } \\
\text { sexual desire, } \\
\text { impotence, headache, } \\
\text { gout, liver damage, } \\
\text { indigestion, fluid } \\
\text { retention and fever. } \\
\text { also it is used for } \\
\text { treating psoriasis, } \\
\text { herpes, skin } \\
\text { problems, foot } \\
\text { fungus, wounds, } \\
\text { ulcers. }\end{array}$ \\
\hline
\end{tabular}




\begin{tabular}{|c|c|c|c|c|c|c|}
\hline No. & $\begin{array}{l}\text { Name of } \\
\text { Species }\end{array}$ & $\begin{array}{l}\text { Common } \\
\text { Name (Arabic } \\
\text { Language) }\end{array}$ & Family & $\begin{array}{l}\text { Part } \\
\text { Used }\end{array}$ & MUV & Ethnobotanical Uses \\
\hline 224. & $\begin{array}{l}\text { Solidago } \\
\text { virgaurea L. }\end{array}$ & 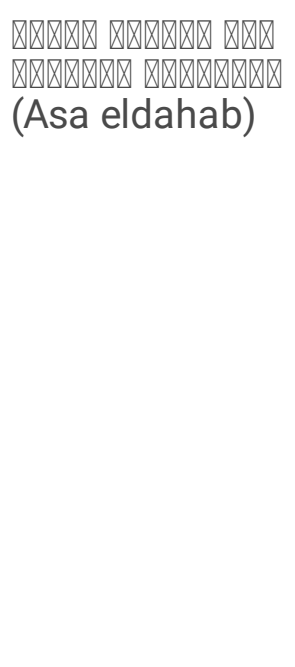 & Asteraceae & $\mathrm{FI}$ & 0.025 & $\begin{array}{l}\text { A decoction of } \\
\text { flowers is used to } \\
\text { treat diabetes and } \\
\text { kidneys disorders, } \\
\text { intestinal diseases, } \\
\text { diseases of the } \\
\text { digestive system and } \\
\text { stomach. The plant } \\
\text { secretes a sticky } \\
\text { substance known } \\
\text { locally as "Nashiha", } \\
\text { which is taken from } \\
\text { the Syrian dialect, } \\
\text { meaning the sticky } \\
\text { substance that } \\
\text { attracts dust and soil. }\end{array}$ \\
\hline 225. & $\begin{array}{l}\text { Sorbus } \\
\text { flabellifolia } \\
\text { (Spach) } \\
\text { Hedl.,p.p.3144 }\end{array}$ & परापा (Gobaira) & Rosaceae & $\mathrm{F}$ & 0.058 & $\begin{array}{l}\text { A decoction of fruits } \\
\text { is used for kidney } \\
\text { diseases, diabetes, } \\
\text { rheumatism, } \\
\text { disorders of the uric } \\
\text { acid, and } \\
\text { menstruation } \\
\text { disturbances. }\end{array}$ \\
\hline 226. & $\begin{array}{l}\text { Sorghum } \\
\text { halepense L. } \\
\text { Pers. }\end{array}$ & प्राप्र (Halyan) & Poaceae & W & 0.043 & $\begin{array}{l}\text { It's a poison plant, } \\
\text { and the plant is used } \\
\text { for the treatment of } \\
\text { urinary tract } \\
\text { disorders, diuretic, } \\
\text { kidney stone. }\end{array}$ \\
\hline 227. & $\begin{array}{l}\text { Stachys } \\
\text { officinalis L. } \\
\text { Trevis. }\end{array}$ & 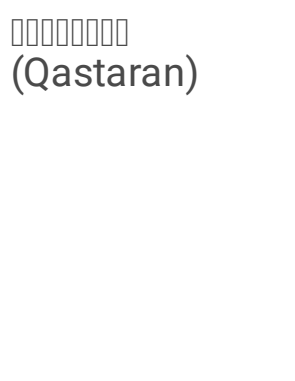 & Lamiaceae & $\begin{array}{l}\mathrm{R}, \\
A p, \mathrm{~L}\end{array}$ & 0.04 & $\begin{array}{l}\text { A decoction of roots } \\
\text { and aerial part is } \\
\text { used as diuretic and } \\
\text { tonic agent, also the } \\
\text { fresh leaves are } \\
\text { placed directly on } \\
\text { sores and wounds to } \\
\text { speed up their } \\
\text { healing. }\end{array}$ \\
\hline 228. & $\begin{array}{l}\text { Stellaria media } \\
\text { (L.) Vill. }\end{array}$ & $\begin{array}{l}\text { (Najmyeh) } \\
\text { (Na) }\end{array}$ & Caryophyllaceae & $\begin{array}{l}\mathrm{R}, \\
\mathrm{Ap}\end{array}$ & 0.018 & $\begin{array}{l}\text { A decoction of roots } \\
\text { and aerial part is } \\
\text { used topically for } \\
\text { cleaning wounds. } \\
\text { Also it is used } \\
\text { internally for } \\
\text { rheumatism, and } \\
\text { gout. }\end{array}$ \\
\hline
\end{tabular}




\begin{tabular}{|c|c|c|c|c|c|c|}
\hline No. & $\begin{array}{l}\text { Name of } \\
\text { Species }\end{array}$ & $\begin{array}{l}\text { Common } \\
\text { Name (Arabic } \\
\text { Language) }\end{array}$ & Family & $\begin{array}{l}\text { Part } \\
\text { Used }\end{array}$ & MUV & Ethnobotanical Uses \\
\hline 229. & $\begin{array}{l}\text { Styrax } \\
\text { officinalis L. }\end{array}$ & 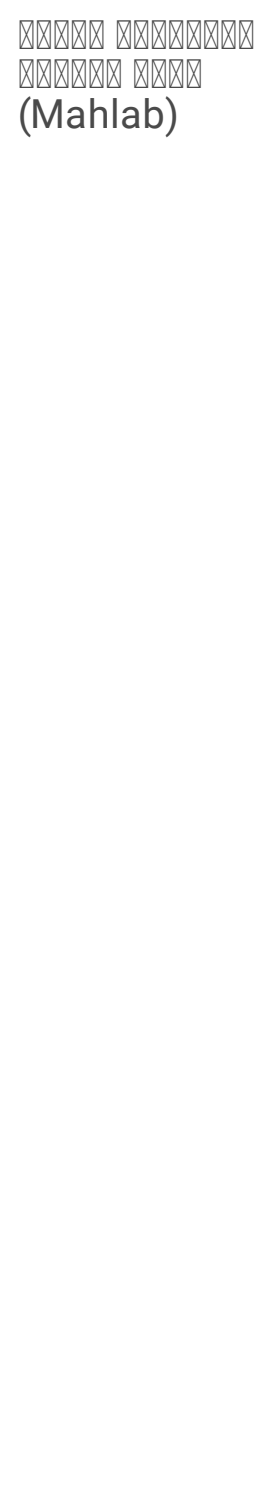 & Styracaceae & G & 0.203 & $\begin{array}{l}\text { It is attributed to } \\
\text { Jableh and is called } \\
\text { styrax gabalite, a } \\
\text { sticky gum that } \\
\text { resembles very white } \\
\text { honey called lactic } \\
\text { honey. Milky is the } \\
\text { gum that is extracted } \\
\text { from the styrax tree } \\
\text { (in English snowbell } \\
\text { bush, in Arabic } \\
\text { Maiah). The gum } \\
\text { extracted from the } \\
\text { tree is used as an } \\
\text { incense and it is usec } \\
\text { to treat cough as } \\
\text { expectorant, } \\
\text { respiratory tract } \\
\text { infection, cold, } \\
\text { hoarseness. } \\
\text { Externally, it is used } \\
\text { as an antiseptic to } \\
\text { treat wounds, ulcers, } \\
\text { rheumatism, gout } \\
\text { and joint diseases. } \\
\text { Also it is used as a } \\
\text { fixative in the } \\
\text { manufacture of } \\
\text { perfumes, and the } \\
\text { gum resin called (Al- } \\
\text { A'bhir) is used in the } \\
\text { manufacture of a } \\
\text { sacred aromatic } \\
\text { incense used in } \\
\text { churches. Burning a } \\
\text { plant is used to keep } \\
\text { snakes away. }\end{array}$ \\
\hline 230. & $\begin{array}{l}\text { Symphytum } \\
\text { officinale L. }\end{array}$ & 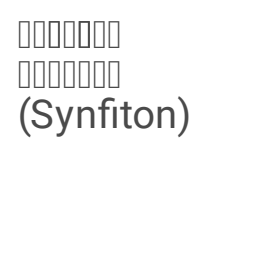 & Boraginaceae & $\begin{array}{l}\mathrm{R}_{\prime} \\
\mathrm{Ap}\end{array}$ & 0.436 & $\begin{array}{l}\text { A decoction of roots } \\
\text { and aerial part is } \\
\text { used topically for } \\
\text { wounds healing, and } \\
\text { internally is used as } \\
\text { expectorant. }\end{array}$ \\
\hline
\end{tabular}




\begin{tabular}{|c|c|c|c|c|c|c|}
\hline No. & $\begin{array}{l}\text { Name of } \\
\text { Species }\end{array}$ & $\begin{array}{l}\text { Common } \\
\text { Name (Arabic } \\
\text { Language) }\end{array}$ & Family & $\begin{array}{l}\text { Part } \\
\text { Used }\end{array}$ & MUV & Ethnobotanical Uses \\
\hline 231. & $\begin{array}{l}\text { Tamarix } \\
\text { articulata Vahl }\end{array}$ & 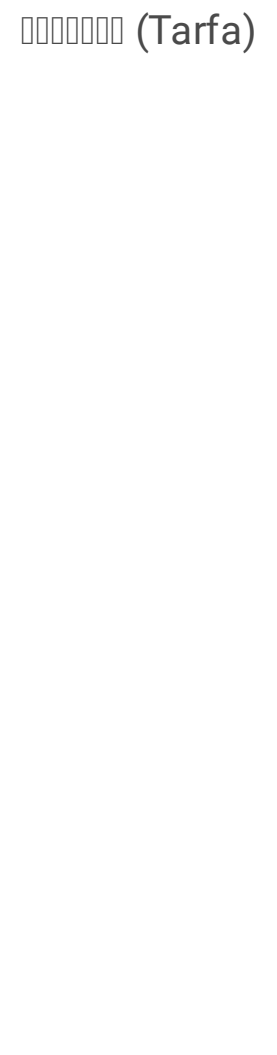 & Tamaricaceae & $L, W$ & 0.09 & $\begin{array}{l}\text { The plant farash } \\
\text { smoke is used for } \\
\text { cold, the salt which is } \\
\text { collected from trees } \\
\text { is used to treat eye } \\
\text { diseases. Its leaves } \\
\text { are cooked to help } \\
\text { treat spleen diseases, } \\
\text { and it is anti-diarrhea } \\
\text { and jaundice, for the } \\
\text { treatment of } \\
\text { toothache as gargle, } \\
\text { and cups of its wood } \\
\text { are prepared to take } \\
\text { advantage of its } \\
\text { properties, and it is } \\
\text { placed on the head } \\
\text { for those affected by } \\
\text { lice and nits in order } \\
\text { to get rid of them, } \\
\text { and the ashes of } \\
\text { farash is scattered on } \\
\text { wet sores and dries } \\
\text { them, especially } \\
\text { sores That is from } \\
\text { burning fire. }\end{array}$ \\
\hline
\end{tabular}




\begin{tabular}{|c|c|c|c|c|c|c|}
\hline No. & $\begin{array}{l}\text { Name of } \\
\text { Species }\end{array}$ & $\begin{array}{l}\text { Common } \\
\text { Name (Arabic } \\
\text { Language) }\end{array}$ & Family & $\begin{array}{l}\text { Part } \\
\text { Used }\end{array}$ & MUV & Ethnobotanical Uses \\
\hline 232. & $\begin{array}{l}\text { Tamus } \\
\text { communis } \mathrm{L} .\end{array}$ & 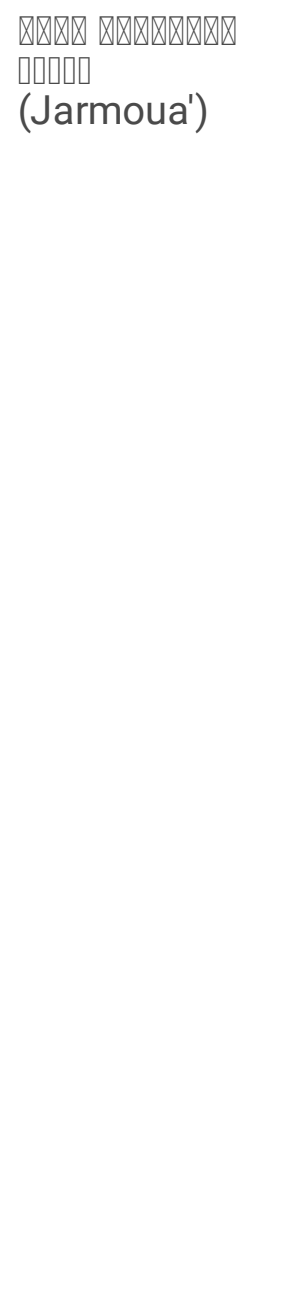 & Dioscoreaceae & $\begin{array}{l}\mathrm{R}, \mathrm{T}, \\
\mathrm{F}\end{array}$ & 0.007 & $\begin{array}{l}\text { All parts of the black } \\
\text { bryony plant, } \\
\text { especially fruits are } \\
\text { highly toxic, causing } \\
\text { severe abdominal } \\
\text { pain, staining and } \\
\text { burning in the mouth, } \\
\text { vomiting and } \\
\text { diarrhea. Fruits often } \\
\text { poison children due } \\
\text { to their } \\
\text { attractiveness, and } \\
\text { cause burns and } \\
\text { blister the mouth and } \\
\text { digestive system, as } \\
\text { well as skin contact } \\
\text { with plant sap, } \\
\text { especially fruit sap, } \\
\text { To its sensitivity, } \\
\text { redness and swelling. } \\
\text { Some local people } \\
\text { use (cutting the roots } \\
\text { or tuber) externally, } \\
\text { as it is applied to the } \\
\text { site of pain in cases } \\
\text { of rheumatism and } \\
\text { sciatica, as it } \\
\text { increases the blood } \\
\text { flow to the skin where } \\
\text { the roots are applied. } \\
\text { And internally it is } \\
\text { used for diabetes. }\end{array}$ \\
\hline 233. & $\begin{array}{l}\text { Tanacetum } \\
\text { vulgare L. }\end{array}$ & 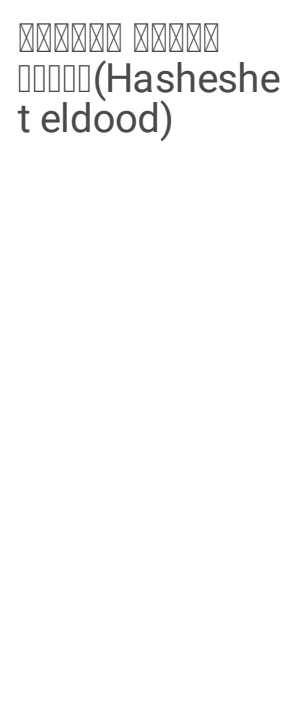 & Asteraceae & Ap & 0.018 & $\begin{array}{l}\text { An infusion of aerial } \\
\text { parts is used as } \\
\text { digestive stimulant, } \\
\text { and to treat coughs, } \\
\text { respiratory tract } \\
\text { infections and } \\
\text { gastritis, and to expel } \\
\text { intestinal worms, and } \\
\text { to treat rheumatism, } \\
\text { venereal diseases } \\
\text { and neurological } \\
\text { diseases. It is also } \\
\text { used externally to } \\
\text { treat wounds. The } \\
\text { aromatic scent of the } \\
\text { plant is used to repel } \\
\text { certain types of ants. }\end{array}$ \\
\hline
\end{tabular}




\begin{tabular}{|c|c|c|c|c|c|c|}
\hline No. & $\begin{array}{l}\text { Name of } \\
\text { Species }\end{array}$ & $\begin{array}{l}\text { Common } \\
\text { Name (Arabic } \\
\text { Language) }\end{array}$ & Family & $\begin{array}{l}\text { Part } \\
\text { Used }\end{array}$ & MUV & Ethnobotanical Uses \\
\hline 234. & $\begin{array}{l}\text { Taraxacum } \\
\text { officinale (L.) } \\
\text { Weber ex } \\
\text { F.H.Wigg. }\end{array}$ & 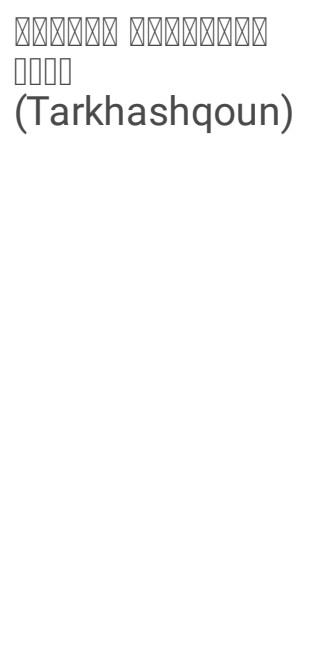 & Asteraceae & W & 0.64 & $\begin{array}{l}\text { An infusion of whole } \\
\text { plant is used as } \\
\text { diuretic, general tonic, } \\
\text { and slimming, and } \\
\text { for liver diseases, } \\
\text { digestive disorders, } \\
\text { diabetes, gallstones, } \\
\text { detoxifying, colon } \\
\text { conditions, joint pain, } \\
\text { rheumatism and } \\
\text { gout. Also it is used } \\
\text { topically to treat skin } \\
\text { diseases such as } \\
\text { psoriasis, eczema, } \\
\text { acne, itching and } \\
\text { varicose veins. }\end{array}$ \\
\hline 235. & $\begin{array}{l}\text { Teucrium } \\
\text { chamaedrys L. }\end{array}$ & $\begin{array}{l}\text { क्वार्या } \\
\text { (Bakhoura) }\end{array}$ & Lamiaceae & W & 0.018 & $\begin{array}{l}\text { An infusion of whole } \\
\text { plant is used for } \\
\text { treatment the kidney } \\
\text { stones. }\end{array}$ \\
\hline 236. & $\begin{array}{l}\text { Teucrium } \\
\text { polium L. }\end{array}$ & प्राप्रा (Jowdeh) & Lamiaceae & Ap & 0.61 & $\begin{array}{l}\text { A decoction of the } \\
\text { aerial parts of the } \\
\text { herb is used to treat } \\
\text { jaundice, peptic ulcer, } \\
\text { arthritis, rheumatism, } \\
\text { and intestinal and } \\
\text { renal colic, and for } \\
\text { cold diseases, and for } \\
\text { cases of poor } \\
\text { appetite and } \\
\text { indigestion, and it is a } \\
\text { diuretic and } \\
\text { menstruation, and it } \\
\text { is cooked with eggs } \\
\text { and eaten as a } \\
\text { treatment for } \\
\text { abdominal pain. }\end{array}$ \\
\hline 237. & $\begin{array}{l}\text { Thymus } \\
\text { syriacus Boiss. }\end{array}$ & प्रा (Zaatar) & Lamiaceae & $\mathrm{L}$ & 0.84 & $\begin{array}{l}\text { An infusion of leaves } \\
\text { is used as anti-cough, } \\
\text { expectorant, } \\
\text { bronchitis, } \\
\text { carminative, } \\
\text { antispasmodic, } \\
\text { anthelmintic, and it is } \\
\text { used for treating } \\
\text { diabetes. }\end{array}$ \\
\hline 238. & $\begin{array}{l}\text { Trifolium } \\
\text { campestre } \\
\text { Schreb. }\end{array}$ & 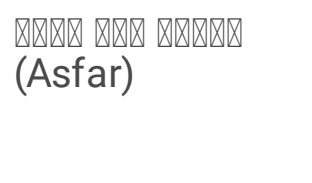 & Fabaceae & W & 0.007 & $\begin{array}{l}\text { An infusion of plant } \\
\text { is used for coughs, } \\
\text { colds, fevers, and as } \\
\text { antirheumatic. }\end{array}$ \\
\hline
\end{tabular}




\begin{tabular}{|c|c|c|c|c|c|c|}
\hline No. & $\begin{array}{l}\text { Name of } \\
\text { Species }\end{array}$ & $\begin{array}{l}\text { Common } \\
\text { Name (Arabic } \\
\text { Language) }\end{array}$ & Family & $\begin{array}{l}\text { Part } \\
\text { Used }\end{array}$ & MUV & Ethnobotanical Uses \\
\hline 239. & $\begin{array}{l}\text { Trifolium } \\
\text { pratense L. }\end{array}$ & 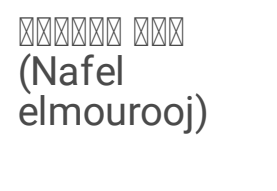 & Fabaceae & L & 0.014 & $\begin{array}{l}\text { An infusion of leaves } \\
\text { is used as diuretic, } \\
\text { and anti- } \\
\text { inflammatory. }\end{array}$ \\
\hline 240. & $\begin{array}{l}\text { Trifolium } \\
\text { purpureum } \\
\text { Loisel. }\end{array}$ & 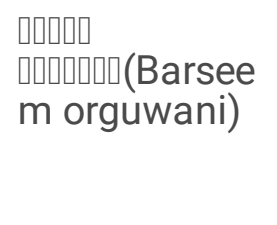 & Fabaceae & Ap & 0.029 & $\begin{array}{l}\text { An infusion of aerial } \\
\text { parts is used for } \\
\text { diarrhea, cough, } \\
\text { insomnia, and } \\
\text { nervousness. }\end{array}$ \\
\hline 241. & $\begin{array}{l}\text { Trifolium } \\
\text { repens } \mathrm{L} .\end{array}$ & प्र (Nafel) & Fabaceae & Ap & 0.03 & $\begin{array}{l}\text { An infusion of aerial } \\
\text { parts has is used in } \\
\text { the treatment of } \\
\text { coughs, colds, fevers, } \\
\text { acute bronchitis, and } \\
\text { for menopausal } \\
\text { syndrome, and it is } \\
\text { used topically for } \\
\text { skin infections. }\end{array}$ \\
\hline 242. & $\begin{array}{l}\text { Trigonella } \\
\text { foenum- } \\
\text { graecum L. }\end{array}$ & 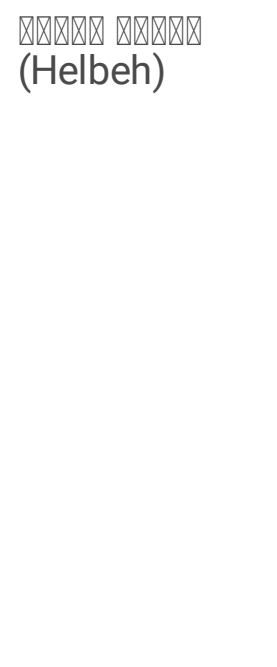 & Fabaceae & $\mathrm{Sd}$ & 0.541 & $\begin{array}{l}\text { A decoction of seeds } \\
\text { is used as } \\
\text { antitussive, } \\
\text { hypercholesterolemia, } \\
\text { galactagogue, } \\
\text { atherosclerosis, } \\
\text { diabetes, blood } \\
\text { pressure, heartburn, } \\
\text { cold, inflammations, } \\
\text { topical massage for } \\
\text { joint and bone pain, } \\
\text { kidney stone, and to } \\
\text { gain weight, the oil of } \\
\text { seed is used topically } \\
\text { for breast } \\
\text { enlargement. }\end{array}$ \\
\hline 243. & $\begin{array}{l}\text { Triticum } \\
\text { aestivum } \mathrm{L} .\end{array}$ & प्सा (Hentah) & Poaceae & $\begin{array}{l}\mathrm{Sd} \\
\mathrm{Pe}\end{array}$ & 0.694 & $\begin{array}{l}\text { An infusion of seeds } \\
\text { is used orally for } \\
\text { constipation and } \\
\text { obesity as the bran } \\
\text { husk is used, external } \\
\text { its used as } \\
\text { compresses for skin } \\
\text { itch. }\end{array}$ \\
\hline 244. & $\begin{array}{l}\text { Tussilago } \\
\text { farfara L. }\end{array}$ & 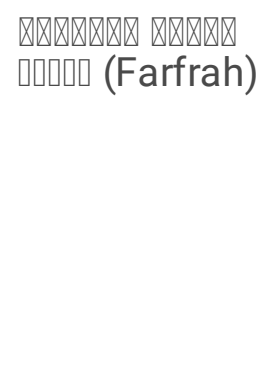 & Asteraceae & $\mathrm{FI}$ & 0.174 & $\begin{array}{l}\text { A decoction of } \\
\text { flowers is used to } \\
\text { treat productive } \\
\text { cough with sputum, } \\
\text { and it is used in } \\
\text { diseases of the } \\
\text { respiratory system } \\
\text { and } \\
\text { bronchopulmonary. }\end{array}$ \\
\hline
\end{tabular}




\begin{tabular}{|c|c|c|c|c|c|c|}
\hline No. & $\begin{array}{l}\text { Name of } \\
\text { Species }\end{array}$ & $\begin{array}{l}\text { Common } \\
\text { Name (Arabic } \\
\text { Language) }\end{array}$ & Family & $\begin{array}{l}\text { Part } \\
\text { Used }\end{array}$ & MUV & Ethnobotanical Uses \\
\hline 245. & $\begin{array}{l}\text { Ulmus } \\
\text { canescens } \\
\text { Melville }\end{array}$ & 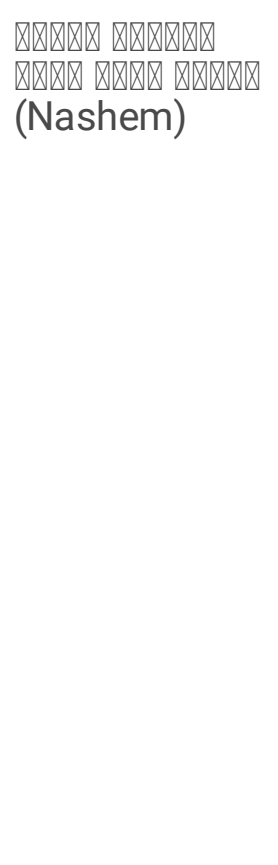 & Ulmaceae & $\begin{array}{l}\text { Bk, } \\
\text { L, Pe }\end{array}$ & 0.083 & $\begin{array}{l}\text { A decoction of the } \\
\text { bark and leaves is } \\
\text { used to stick soft } \\
\text { wounds. If soaked } \\
\text { with vinegar, it is } \\
\text { used to expel phlegm. } \\
\text { The crushed peels } \\
\text { with white medical } \\
\text { vaseline is used to } \\
\text { dress the affected } \\
\text { skin areas, astringent, } \\
\text { cleanser for the skin, } \\
\text { especially in cases of } \\
\text { impetigo, freckles } \\
\text { and freckles, Eau } \\
\text { d'Orme water is used } \\
\text { in cleaning and } \\
\text { disinfecting wounds } \\
\text { and in washing eyes } \\
\text { affected by } \\
\text { conjunctivitis. }\end{array}$ \\
\hline 246. & Urtica dioica L. & प्रा (Kurrais) & Urticaceae & $\begin{array}{l}\mathrm{Fl} \\
\mathrm{Sd} \\
\mathrm{R}\end{array}$ & 0.687 & $\begin{array}{l}\text { An infusion of } \\
\text { flowering part and } \\
\text { seeds and roots is } \\
\text { used orally for } \\
\text { rheumatism, joint and } \\
\text { chest pain, diabetes, } \\
\text { anemia, digestive } \\
\text { diseases, kidney } \\
\text { disease, gall and } \\
\text { diuretic, cough and } \\
\text { respiratory system, } \\
\text { and for cessation of } \\
\text { nosebleeds, the oil is } \\
\text { used for cases of hair } \\
\text { loss and cases of } \\
\text { burns. }\end{array}$ \\
\hline 247. & $\begin{array}{l}\text { Verbascum } \\
\text { thapsus } \mathrm{L} .\end{array}$ & 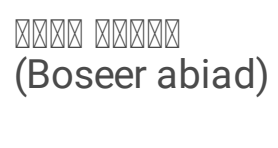 & Scrophulariaceae & $\mathrm{Fl}, \mathrm{L}$ & 0.054 & $\begin{array}{l}\text { A decoction of } \\
\text { flowers and leaves is } \\
\text { used as diuretic. }\end{array}$ \\
\hline 248. & $\begin{array}{l}\text { Verbena } \\
\text { officinalis } \mathrm{L} .\end{array}$ & 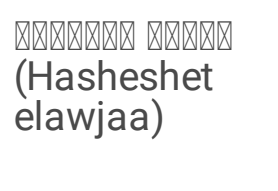 & Verbenaceae & Ap & 0.065 & $\begin{array}{l}\text { An infusion of aerial } \\
\text { parts is used as } \\
\text { antispasmodic and } \\
\text { general tonic. }\end{array}$ \\
\hline 249. & $\begin{array}{l}\text { Valeriana } \\
\text { officinalis } \mathrm{L} .\end{array}$ & 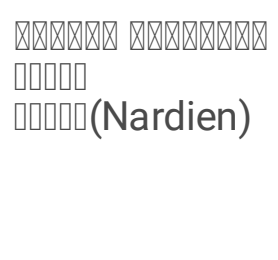 & Caprifoliaceae & $\mathrm{R}$ & 0.163 & $\begin{array}{l}\text { A decoction of roots } \\
\text { is used as sedative } \\
\text { and hypnotic, for } \\
\text { treating mild sleep } \\
\text { disorders and } \\
\text { nervous tension. }\end{array}$ \\
\hline
\end{tabular}




\begin{tabular}{|c|c|c|c|c|c|c|}
\hline No. & $\begin{array}{l}\text { Name of } \\
\text { Species }\end{array}$ & $\begin{array}{l}\text { Common } \\
\text { Name (Arabic } \\
\text { Language) }\end{array}$ & Family & $\begin{array}{l}\text { Part } \\
\text { Used }\end{array}$ & MUV & Ethnobotanical Uses \\
\hline 250. & $\begin{array}{l}\text { Verbascum } \\
\text { tripolitanum } \\
\text { Boiss. }\end{array}$ & 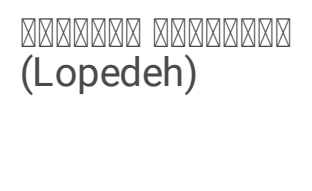 & Scrophulariaceae & $\mathrm{FI}$ & 0.007 & $\begin{array}{l}\text { A decoction of } \\
\text { flowers is used as } \\
\text { expectorant and } \\
\text { diuretic. }\end{array}$ \\
\hline 251. & Vicia faba L. & प्रा (Fool) & Fabaceae & $\mathrm{Sd}$ & 0.403 & $\begin{array}{l}\text { Seeds are used as } \\
\text { tonic, diuretic, } \\
\text { beneficial to the } \\
\text { heart, and good for } \\
\text { women in the } \\
\text { menopause stage, } \\
\text { maintains the level of } \\
\text { sugar in the blood, } \\
\text { and Increased } \\
\text { hemoglobin rate. }\end{array}$ \\
\hline 252. & Vicia hybrida L. & 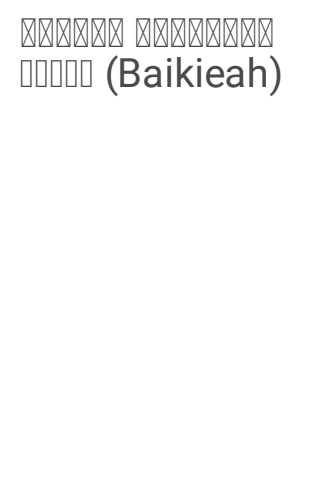 & Fabaceae & $\mathrm{Sd}$ & 0.05 & $\begin{array}{l}\text { Its seeds are used } \\
\text { against smallpox and } \\
\text { erysipelas, and for } \\
\text { skin edema. It is not } \\
\text { used as a foodstuff } \\
\text { due to its toxic } \\
\text { elements that do not } \\
\text { go away until after } \\
\text { soaking in cold water } \\
\text { for } 24-36 \text { hours, and } \\
\text { then it is cooked with } \\
\text { salt water. }\end{array}$ \\
\hline 253. & $\begin{array}{l}\text { Vigna sinensis } \\
\text { (L.) Savi ex } \\
\text { Hausskn. }\end{array}$ & 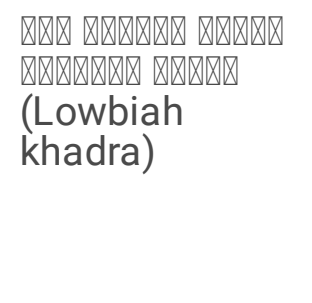 & Fabaceae & $\begin{array}{l}\text { Sd, } \\
S\end{array}$ & 0.41 & $\begin{array}{l}\text { Green seeds and } \\
\text { stems are used } \\
\text { cooked to rid the } \\
\text { body of toxins, to } \\
\text { slim, to protect the } \\
\text { heart, to diabetics, to } \\
\text { depressive states. }\end{array}$ \\
\hline 254. & $\begin{array}{l}\text { Viola suavis } \\
\text { M.Bieb. }\end{array}$ & $\begin{array}{l}\text { (Banafsaj) } \\
\text { (Band }\end{array}$ & Violaceae & $\mathrm{FI}, \mathrm{L}$ & 0.556 & $\begin{array}{l}\text { An infusion of } \\
\text { flowers and leaves is } \\
\text { used to treat } \\
\text { bronchitis and to } \\
\text { facilitate spotting in } \\
\text { respiratory tract } \\
\text { infections. And it is } \\
\text { used in the form of } \\
\text { compresses for the } \\
\text { eyelids affected by } \\
\text { conjunctivitis, and in } \\
\text { hot baths for the feet } \\
\text { to treat insomnia. }\end{array}$ \\
\hline
\end{tabular}




\begin{tabular}{|c|c|c|c|c|c|c|}
\hline No. & $\begin{array}{l}\text { Name of } \\
\text { Species }\end{array}$ & $\begin{array}{l}\text { Common } \\
\text { Name (Arabic } \\
\text { Language) }\end{array}$ & Family & $\begin{array}{l}\text { Part } \\
\text { Used }\end{array}$ & MUV & Ethnobotanical Uses \\
\hline 255. & $\begin{array}{l}\text { Vitex agnus- } \\
\text { castus L. }\end{array}$ & 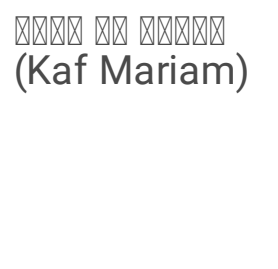 & Verbenaceae & $\mathrm{F}, \mathrm{Sd}$ & 0.585 & $\begin{array}{l}\text { A decoction of fruits } \\
\text { and seeds is used to } \\
\text { reduce premenstrual } \\
\text { symptoms, treat } \\
\text { acne, and treat } \\
\text { prostate enlargement. }\end{array}$ \\
\hline 256. & Vitis vinifera $\mathrm{L}$. & 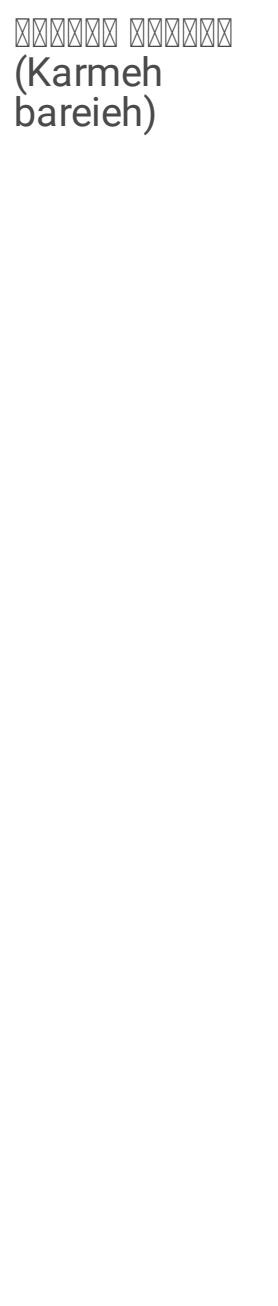 & Vitaceae & $\mathrm{F}, \mathrm{Sd}$ & 0.21 & $\begin{array}{l}\text { Grapes fruits are } \\
\text { popularly used as an } \\
\text { optimal food to } \\
\text { revitalize the body, } \\
\text { especially the brain, } \\
\text { and it is a good food } \\
\text { for the heart, and is } \\
\text { considered one of the } \\
\text { most important } \\
\text { sources of energy for } \\
\text { muscles, besides the } \\
\text { fruits are used for } \\
\text { constipation and } \\
\text { gout, the seeds are } \\
\text { used as } \\
\text { antihypertensives } \\
\text { and reduce blood } \\
\text { sugar, The seeds are } \\
\text { used for menstrual } \\
\text { cramps and period } \\
\text { regulation, dried fruits } \\
\text { called (zabeb for red } \\
\text { and ashlamesh for } \\
\text { white) are used to } \\
\text { strengthen the body's } \\
\text { immunity, and as } \\
\text { general tonic, the } \\
\text { seed oil is used as } \\
\text { tonic for hair, and for } \\
\text { skin diseases, the } \\
\text { fruits vinegar also } \\
\text { used for slimming. }\end{array}$ \\
\hline 257. & $\begin{array}{l}\text { Xanthium } \\
\text { strumarium L. }\end{array}$ & प्राप्र (Hasak) & Asteraceae & Sd, L & 0.054 & $\begin{array}{l}\text { A decoction of seeds } \\
\text { and leaves is used for } \\
\text { infertility and } \\
\text { impotency in males, } \\
\text { galactogogue. }\end{array}$ \\
\hline 258. & Zea mays L. & 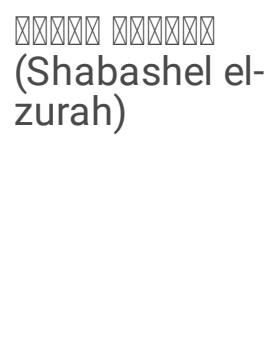 & Poaceae & Si & 0.72 & $\begin{array}{l}\text { An infusion of corn } \\
\text { silk is used for } \\
\text { regulating blood } \\
\text { sugar, reducing } \\
\text { cholesterol, as } \\
\text { diuretic for kidney } \\
\text { stone, weight loss, } \\
\text { gout, bedwetting. }\end{array}$ \\
\hline
\end{tabular}


L: Leaves, S: Stem, R: Root, W: Whole Plant, Fl: Flower, F: Fruit, Sd: Seed, Rm: Rhizome, Rs: Resin, Ap: Aerial Parts, Bb: Bulb, Sk: Sticks, Sh: Shoots, T: Tubers, Bu: Buds, Bk: Bark, G: Gum, P :Pods, Ph: Phloem, Pe: Peel, Br: Branches, Si: Silk.

\subsection{Botanical families of plants used}

The most commonly mentioned family is Asteraceae (13.12\%), followed by Fabaceae (8.49\%), then Rosaceae (7.33\%) and Lamiaceae (6.56\%), Poaceae (5.79\%), Apiaceae (3.08\%), Anacardiacea and Boraginaceae and Caryophyllaceae (1.93\%), then Alliaceae, Brassicaceae, Cuppressaceae, Malvaceae, and Oleaceae (1.54\%), Caprifoliaceae, Cistaceae, Convolvulaceae, Cucurbitaceae, Fagaceae, Papaveraceae, Pinaceae, Polygonaceae, and Primulaceae (1.15\%), Amaranthaceae, Apocynaceae, Araceae, Cyperaceae, Dipsacaceae, Ericaceae, Euphorbiaceae, Hypericaceae, Iridaceae, Myrtaceae, Orchidaceae, Polygalaceae, Portulacaceae, Pteridaceae, Ranunculaceae, Rhamnaceae, Rubiaceae, Rutaceae, Salicaceae, Scrophulariaceae, Solanaceae, and Verbenaceae (0.77\%), then Acanthaceae, Aceraceae, Acoraceae, Araliaceae, Aristolochiaceae, Asparagaceae, Betulaceae, Cactaceae, Campanulaceae, Cannabaceae, Capparaceae, Cornaceae, Cruciferae, Dioscoreaceae, Ephedraceae, Equisetaceae, Frankeniaceae, Gentianaceae, Geraniaceae, Juglandaceae, Juncaceae, Lauraceae, Linaceae, Meliaceae, Menyanthaceae, Moraceae, Plantaginaceae, Platanaceae, Plumbaginaceae, Punicaceae, Santalaceae, Smilacaceae, Styracaceae, Tamaricaceae, Ulmaceae, Urticaceae, Violaceae, and Vitaceae (0.38\%). (Figure 2)

\subsection{Medicinal use plants (MUV)}

Medicinal use plants (MUV) are utilized to find the most frequently used plant species in the study area. Its value ranged from 0.003 to 0.934 (Table 2). The calculated results of MUV showed that Olea europaea L., Origanum syriacum L. was ranked first (MUV=0.934) followed by Laurus nobilis L. (MUV=0.923), Lavatera punctata All., Malva sylvestris L. (MUV=0.916), then Allium cepa L. (MUV=0.909), Rosmarinus officinalis $\mathrm{L}$. (MUV=0.901), Malus silvestris L. Mill. (MUV=0.89), Allium trifoliatum Cirillo (MUV=0.887), while the lowest value was found for Fumana thymifolia (L.) Spach and Cistus creticus L. (MUV=0.003).

\subsection{Medicinal parts of the plant used}

The analysis of the ethnobotanical data showed that coastal region was best suited to the medicinal plant and rangeland. Ethnobotanical use categories showed that leaves were commonly used parts for making indigenous recipes a (21.06\%), followed by roots (13.6\%) and flowers (11.4\%) and seeds (11.2\%) and fruits $(10.93 \%)$ and aerial parts $(10.1 \%)$ then the others parts of plant are rarely used (Figure 3$)$.

\subsection{Modes and conditions of medicine preparation}

The analysis of the ethnobotanical data showed that the most of the herbal recipes (75.2\%) were made from fresh material followed by their dried form (24.8\%). The recipes in the most cases were obtained from single herb, but some of recipes were prepared together, and there is a famous local mixture called Damask tisane (zhourate Shamieh) or (Syrian zahraa) [117]. The major solvent was water (68\%), honey (17\%), seeds oil (10\%) and vinegar (5\%). A mode of traditional medicine preparation reported was an infusion (40.12\%), followed by 
decoction (21.35\%), then other method such as juice, roasted, cooked, boiled, powder, and soak in oils $(38.53 \%)$. Considered according to results that most of the plant preparations are used orally. (Table 2).

\subsection{Ethno medicinal information about treatment the different diseases:}

The results of questionnaires showed that $15 \%$ of the informants were diagnosed with their diseases by a doctor, and $38 \%$ were diagnosed with a conventional therapist, and $47 \%$ self-diagnosed their diseases, while the results of the questionnaires showed that the evaluation of the treatment by informants as following ( $64 \%$ relied on the disappearance of symptoms, and $22 \%$ Through the results of laboratory analysis, $14 \%$ adopted other methods such as chest radiography, adopting the attending physician's opinion and clinical observation of the improvement of skin diseases, and some of them depended on psychological comfort during treatment as evidence of improvement).

Of these studied plants, 185 are used to treat digestive disorders, 118 for respiratory diseases, including asthma, bronchitis and coughs, 91 for several skin diseases, 87 for kidney and urinary tract disorders, 78 for diabetes, 18 for nervous system disorders, and a few plants for treatment the other diseases such as enhance the body's immunity, hemorrhoids, fever, heart disorders, infertility and impotence, treating several types of cancer, increasing breast milk production, losing weight, lowering cholesterol, increasing weight, anemia, blood disorder, anti-toxicant, arthritis and pain, typhoid disorder, infections, gynecological diseases, eye inflammation, anti-toxicant, mouth sores (Figure 4); Many of them are still used today, especially those plants recommended for internal uses such as traditional medicinal teas, which mainly consist of remedies for obesity, weight loss, colds, colds, digestive disorders, abdominal pain, constipation and some skin diseases, and there are many factories that produce medicinal tisane.

\section{Discussion}

The use of traditional Arabic medicine (TAM) has spread to treat various diseases in Syria since ancient time. They are cost-effective with fewer side effects and are more suitable for long-term use compared with chemically synthesized medicines.

In this research a questionnaire was administered to the 475 informants (local inhabitants) of 70 villages through face-to-face interviews, we listed 258 medicinal plants belonging to 83 families in alphabetical order with the parts used and the method of preparation according to their therapeutic use. Of these studied plants, 185 are used to treat digestive disorders, 118 for respiratory diseases, 91 for several skin diseases, 87 for kidney and urinary tract disorders, 78 for diabetes, 18 for nervous system disorders, and a few plants for treatment the other diseases which are commonly spread in study area. The calculated results of medicinal use-value (MUV) showed that Olea europaea L., Origanum syriacum L. was ranked first (MUV=0.934), while the lowest value was found for Fumana thymifolia (L.) Spach and Cistus creticus L. (MUV=0.003).

Ethnobotanical use categories indicated that there is large use of medicinal herbs in the area of study, most of them are wild. Increased exploitation of medicinal plants by the local population, collectors and dealers of herbal medicines, in line with the demand from the pharmaceutical industry. This caused a sharp decrease in the occurrence and products of medicinal plants. Grazing, deforestation by cutting down trees for heating, and fires were mainly responsible for the reduction of medicinal plants. so that the government is working on 
developing strategies to conserve wild plant diversity. Some people collect the medicinal plants for an income. They uproot and collect each part of the medicinal plants in non-scientific way. Thus, to date, a few articles devoted to traditional medicine of Syria have been published for one on the folk medicine in Aleppo governorate (Alachkara et al. 2011), and another for the use of "Zahraa" (Syrian traditional tisane) (Carmona et al. 2005), and third one on the medicinal plants in Golan (Said et al. 2002), which is an occupied Syrian territory.

It is hoped that this research will contribute a lot in providing a useful information on the conservation and sustainable use of the natural resources of the area.

The information contained in the questionnaire was compared with ethnomedicine studies in the countries surrounding Syria such as Lebanon (Taha et al. 2013), Jordan (Lev \& Amar 2002; Al-Qura'n 2009), Palestine (Friedman et al. 1986; Kaileh et al. 2007), Iraq (Al-Douri 2000) and Turkey (Yesilada et al. 1995; Sezik et al. 2001). We noticed a similarity in a lot of traditional uses in Syria, Lebanon, Palestine, and Jordan, the reason for this is due to mutual history of these areas were previously called Bilad Al-Sham; and there is some similarity with a smaller number of folk uses between Syria and Iraq, and there is a difference in the folk uses described between Syria and Turkey.

We did not record significant differences in phytomedicines consumption customs between interviewees of different religions In general, phytomedicines consumption was often explained and justified by interviewees as family tradition. We did not detect any gender-related differences in phytomedicines consumption. However, there weren't gender differences concerning the common traditional use of medicinal plants. The ethno-medicine data presented here in imply that medicinal plants are important as food and particularly as medicine (traditional healing) for various local people. While chemical medicinal treatments are becoming commonplace, traditional medications are still of huge importance in many rural, poor and remote places.

There is no doubt that its study will provide many new data that could contribute to further pharmacological discoveries by identifying the active ingredients and their mechanism of effect by doing a lot of pharmacological work to confirm the alleged biological activities of these plants, and the possibility of developing new pharmaceutical formulas cannot be excluded depending on Syrian medicinal plants and their folk uses. as the discovery of artemisinin from Artemisia annua, based on ethnobotanical information (Acton \& Klayman 1985), serves as evidence that it is possible to find new and effective medicines using data from traditional medicine.

\section{Limitations}

There is insufficient information about the pharmacokinetic efficacy of the medicinal plant species in this study. These herbs that have been reported that have been used traditionally as adjuvant to relieve and treat some diseases.

\section{Conclusion}

A large portion of the uses of medicinal plants mentioned in Syria are still under study. There is no doubt that its study will provide many new data that could contribute to further pharmacological discoveries by 
identifying the active ingredients and their mechanism of effect by doing a lot of pharmacological work to confirm the alleged biological activities of these plants.

\section{Declarations}

\section{Financial support (Funding)}

This study did not receive any particular gift from funding companies in the public, commercial, or not-forprofit sectors.

\section{Declaration of Competing interests}

We declare that there is no conflict of interest with any business organization concerning the study.

\section{Authors' Contributions}

C.H.: Data collection, methodology, investigation, compiled the literature sources, data analysis, evaluation, and interpretation, realization manuscript, helped in data, and made a substantial contribution to data analysis. A.N.: Evaluation the clinical data, performed data analysis and drafted the manuscript. M.I.H.A.: Review \& editing, designed the research and identification of plant species. All contributors understand and accepted the final document.

\section{Acknowledgments}

The authors would like to express their gratitude to Mr. Besher Yazji, Mr. Fares Kallas, and Dr. M.Yasaar Abdeen president of Damascus University, and Dr. Jameela Hasian, Dr. Mays Khazem, Dr. Rasha El-Khateeb at Damascus University - Faculty of Pharmacy, Dr. Haifa Al-Ali, Dr. Aoula Moustapha at Al Baath University Faculty of Pharmacy, Dr. Fawaz Shehneh, Dr. Adawia Kitaz at Aleppo University - faculty of Pharmacy, and Dr. Ahmad Karaali at Tishreen University - Higher Institute of Marine Research, and to Mr. Fawaz Saleh and Dr. Nasser Thallaj Mr. Hisham Jabaji at Al Rasheed Private University, and Dr. Emad Kadi (God rest his soul), Dr. Abdel Aleem Bello, Dr. Bayan Tiba, Dr. Jalal Fandi the taxonomic specialists. Their thanks are also extended to The Syria Trust for Development (Mr. Shadi Alelshi, Mrs. Areen Al-Ali, Mr. Houssam Akel, Mr. Rafed Al-Ali) and the Syrian syndicate of pharmacists board and Dr. Wafa kishi the head, the Syrian Scientific Society for Herbal Medicines and Complementary Medicines and Nutrition Chemist. Hisham Kasem for making this work possible. also they are thankful to the informants in this study for their valuable help in the documentation of indigenous ethnopharmacological knowledge.

\section{Availability of data and material}

Supplementary materials related to this article may be obtained from the authors upon request.

\section{References}

Acton N, Klayman D. 1985. Artemisitene, a new sesquiterpene lactone endoperoxide from artemisia annua. Planta Med. 51: 441- 442. 
Ahmad K.S., Kayani W.K., Hameed M., Ahmad F., Nawaz T. 2012. Floristic diversity and ethnobotany of Senhsa, District Kotli, Azad Jammu \& Kashmir (Pakistan). Pak J Bot. 44: 195-201.

Alachkara A, Jaddouh A, Elsheikh MS, Bilia AR, Vincieri FF. 2011. Traditional medicine in syria: folk medicine in Aleppo governorate. Nat. Prod. Commun. 6: 79- 84.

Alam N., Shinwari Z.K., llyas M., Ullah Z. 2011. Indigenous knowledge of medicinal plants of Chagharzai Valley, District Buner, Pakistan. Pak J Bot. 43: 773-780.

Al-Douri N. 2000. A survey of medicinal plants and their traditional uses in Iraq. Pharm. Biol. 38: $74-79$.

Al-Qura'n S. 2009. Ethnopharmacological survey of wild medicinal plants in Showbak, Jordan. J. Ethnopharmacol. 123: 45- 50.

Amjad M.S., Arshad M., Hussain M.Z. 2013. An overview of human-plant interaction in Nikyal rangeland district Kotli Azad Jammu and Kashmir. Afr J Plant Sci. 7(12): 571-576.

Amjad M.S., Arshad M., Qureshi R. 2015. Ethnobotanical inventory and folk uses of indigenous plants from Pir Nasoora National Park, Azad Jammu and Kashmir, Asian Pac J Trop Biomed . 5(3): 234-241

Campbell M.J., Hamilton B., Shoemaker M., Tagliaferri M., Cohen I., Tripathy D. 2002. Antiproliferative activity of Chinese medicinal herbs on breast cancer cells in vitro. Anticancer Res 2002; 22: 3843-3852

Carmona MD, Llorach R, Obon C, Rivera D. 2005. Zahraa, a Unani multicomponent herbal tea widely consumed in Syria: components of drug mixtures and alleged medicinal properties. J. Ethnopharmacol. 102: 344-350.

Chaachouaya N., Douirab A., Zidaneb L. 2021. COVID-19, prevention and treatment with herbal medicine in the herbal markets of Salé Prefecture, North-Western Morocco, European Journal of Integrative Medicine. Volume 42.

Che C., George V., ljinu T., Pushpangadan P., Andrae-Marobela K. 2017. Traditional medicine: pharmacognosy. [place unknown]: Academic Press. p.15.

Falk E (Editor-in-Chief): Traditional medicine sharing experiences from the field, living heritage series, [Internet]. 2017. Korea: UNESCO; [cited 2021 March 21]. Available from: http://www.ichngoforum.org/

Friedman J, Yaniv Z, Dafni A, Palewitch D. 1986. A preliminary classification of the healing potential of medicinal plants, based on a rational analysis of an ethnopharmacological field survey among Bedouins in the Negev desert. J. Ethnopharmacol.16: 275- 287.

Hameed M., Ashraf M., Al-Quriany F., Nawaz T., Ahmad M.A., Younis A., et al. 2011. Medicinal flora of the Cholistan desert: a review. Pak J Bot. 43: 39-50.

Hamidé A. , Polk W., Smith C., Ochsenwald W., Commins D. et al. Syria. Encyclopedia Britannica. [Internet]. 2021. Chicago: USA; [cited 2021 March 21]. Available from: https://www.britannica.com/place/Syria 
Husain S.Z., Malik R.N., Javaid M., Bibi S. 2008. Ethnobotanical properties and uses of medicinal plants of Morgha Biodiversity Park Rawalpindi. Pak J Bot. 40(5): 1897-1911.

Ibrar M., Hussain F., Sultan A. 2007. Ethnobotanical studies on plant resources of Ranyal hills, District Shangla, Pakistan. Pak J Bot. 39(2): 329-337.

Kaileh M, Berghe WV, Boone E, Essawi T, Haegeman G. 2007. Screening of indigenous Palestinian medicinal plants for potential anti-inflammatory and cytotoxic activity. J. Ethnopharmacol. 113: 510- 516.

Lev E, Amar Z. 2002. Ethnopharmacological survey of traditional drugs sold in the Kingdom of Jordan. J. Ethnopharmacol. 82:131-45.

Mahmood A., Qureshi R.A., Mahmood A., Sangi Y., Shaheen H., Ahmad I., et al. 2011. Ethnobotanical survey of common medicinal plants used by people of district Mirpur, AJK, Pakistan. J Med Plants Res. 5(18): 44934498.

Montvale NJ. 2000. PDR for Herbal Medicines. 2nd ed. [place unknown]: Medical Economics Company.

Said O, Khalil K, Fulder S, Azaizeh H. 2002. Ethnopharmacological survey of medicinal herbs in Israel, the Golan Heights and the West Bank region. J. Ethnopharmacol. 83:251-265.

Sezik E, Yesilada E. Honda G, Takaishi Y, Takeda Y, Tanaka T. 2001. Traditional medicine in Turkey - Folk medicine in Central Anatolia. J. Ethnopharmacol.75: 95-115.

Tabuti J.R.S., Lye K.A., Dhillion S.S. 2003. Traditional herbal drugs of Bulamogi, Uganda: Plants, use and administration J. Ethnopharmacol., 88 (1): p. 19-44, 10.1016/S0378-8741(03)00161-2

Taha D, Knio, Zabta K, Zabta S, Kreydiyyeh, Elias S, Elias B. 2013. Survey of medicinal plants currently used by herbalists in Lebanon. Pak. J. Bot. 45: 543-555.

Tenté A., Lougbégnon O., Houessou G., Dossou M., Codjia J. 2012. Etude ethnobotanique des ressources forestières ligneuses de la forêt marécageuse d'Agonvè et terroirs connexes au Bénin Tropicultura. 30 (1): p. 41-48.

World Health Organization (WHO): WHO traditional medicine strategy 2002-2005. [Internet]. 2002. Geneva. WHO Press [cited 2021 March 21]. Available from: https://apps.who.int/

World Health Organization (WHO): WHO medicines strategy countries at core 2004-2007. [Internet]. 2004. Geneva: WHO Press. [cited 2021 March 21]. Available from: https://apps.who.int/

World Health Organization (WHO): National policy on traditional medicine and regulation of herbal medicines report of a WHO global survey. [Internet]. 2005. Geneva: WHO Press [cited 2021 March 21]. Available from: https://apps.who.int/

World Health Organization (WHO): WHO traditional medicine strategy 2014-2023. [Internet]. 2013. Geneva. WHO Press [cited 2021 March 21]. Available from: https://apps.who.int/ 
Yaseen T. 2010. Phytophthora citrophthora is the predominant Phytophthora species in Syrian citrus groves. Phytopathologia Mediterranea. 49(2): 205-211.

Yaseen G. et al. 2015. Ethnobotany of medicinal plants in the Thar Desert (Sindh) of Pakistan, J. Ethnopharmacol. 163: p. 43-59, 10.1016/j.jep.2014.12.053

Yesilada E, Honda G, Sezik E, Tabata M, Fujita T, Tanaka T, Takeda Y, Takaishi Y. 1995. Traditional medicine in Turkey - folk medicine in the inner Taurus mountains. J. Ethnopharmacol. 46:133-152.

\section{Figures}




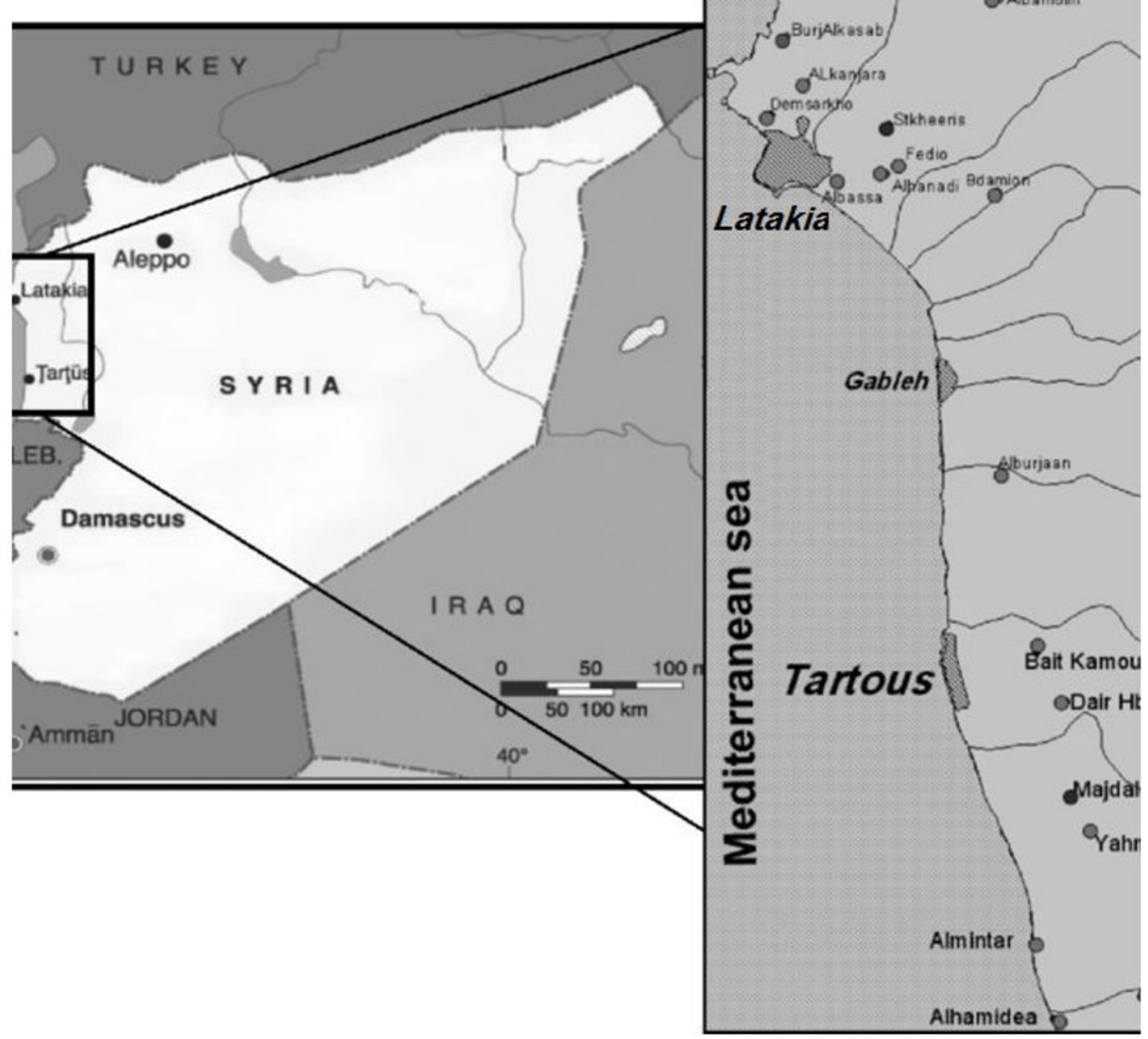

\section{Figure 1}

Geographical Location of the study area, Latakia \& Tartus (Yaseen 2010). Note: The designations employed and the presentation of the material on this map do not imply the expression of any opinion whatsoever on the part of Research Square concerning the legal status of any country, territory, city or area or of its authorities, or concerning the delimitation of its frontiers or boundaries. This map has been provided by the authors. 


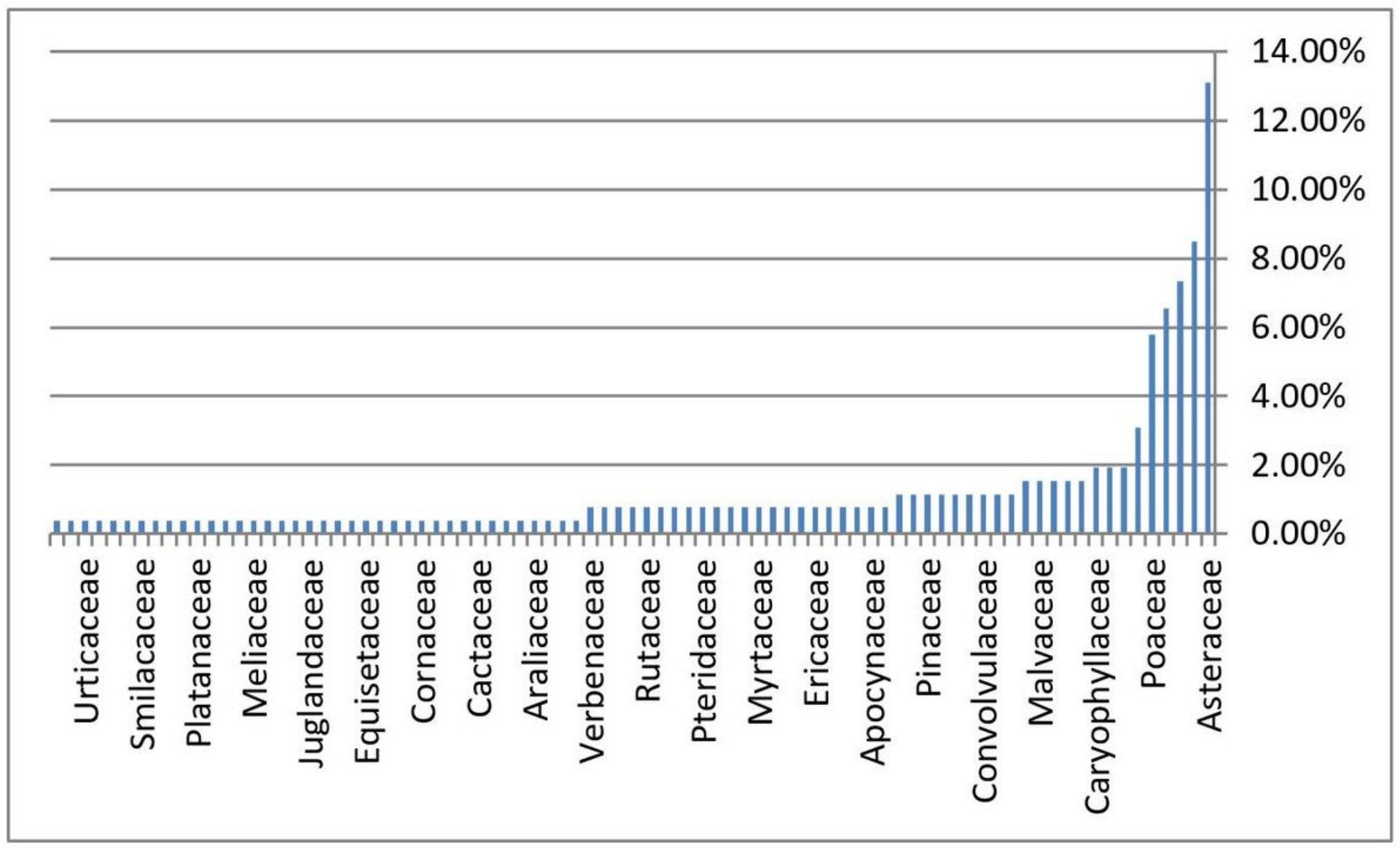

Figure 2

Plant families common used in ethnomedicinal survey of Western region in Syria (Latakia and Tartus). 


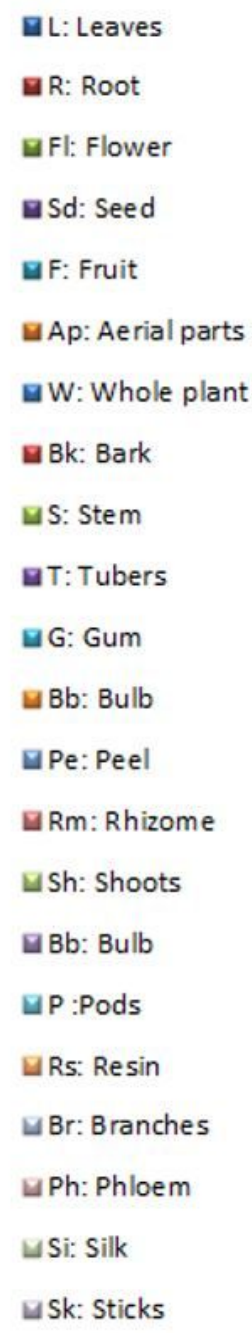
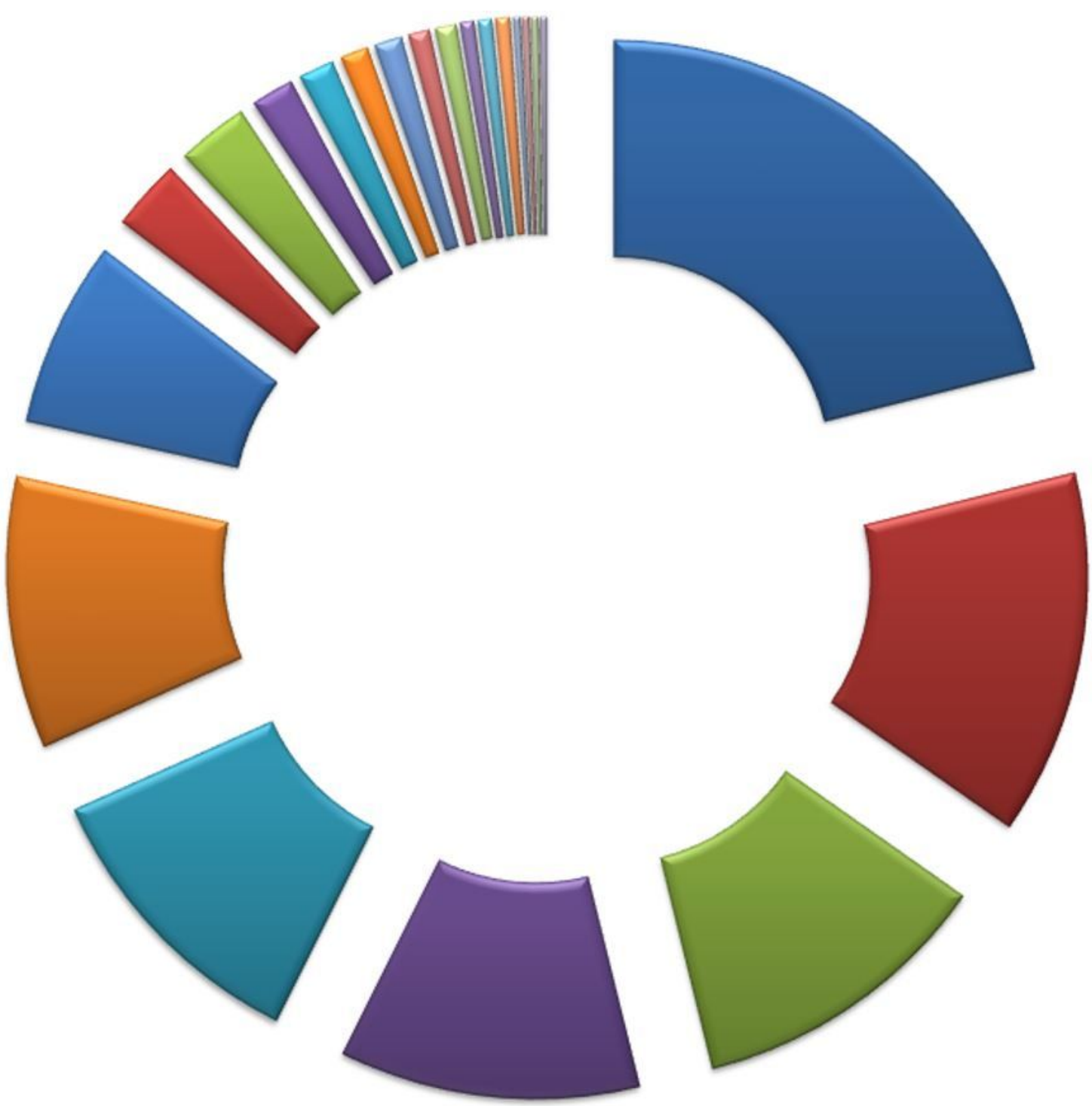

\section{Figure 3}

Parts used for ethnomedicinal purpose of flora related to Western region in Syria (Latakia and Tartus). 


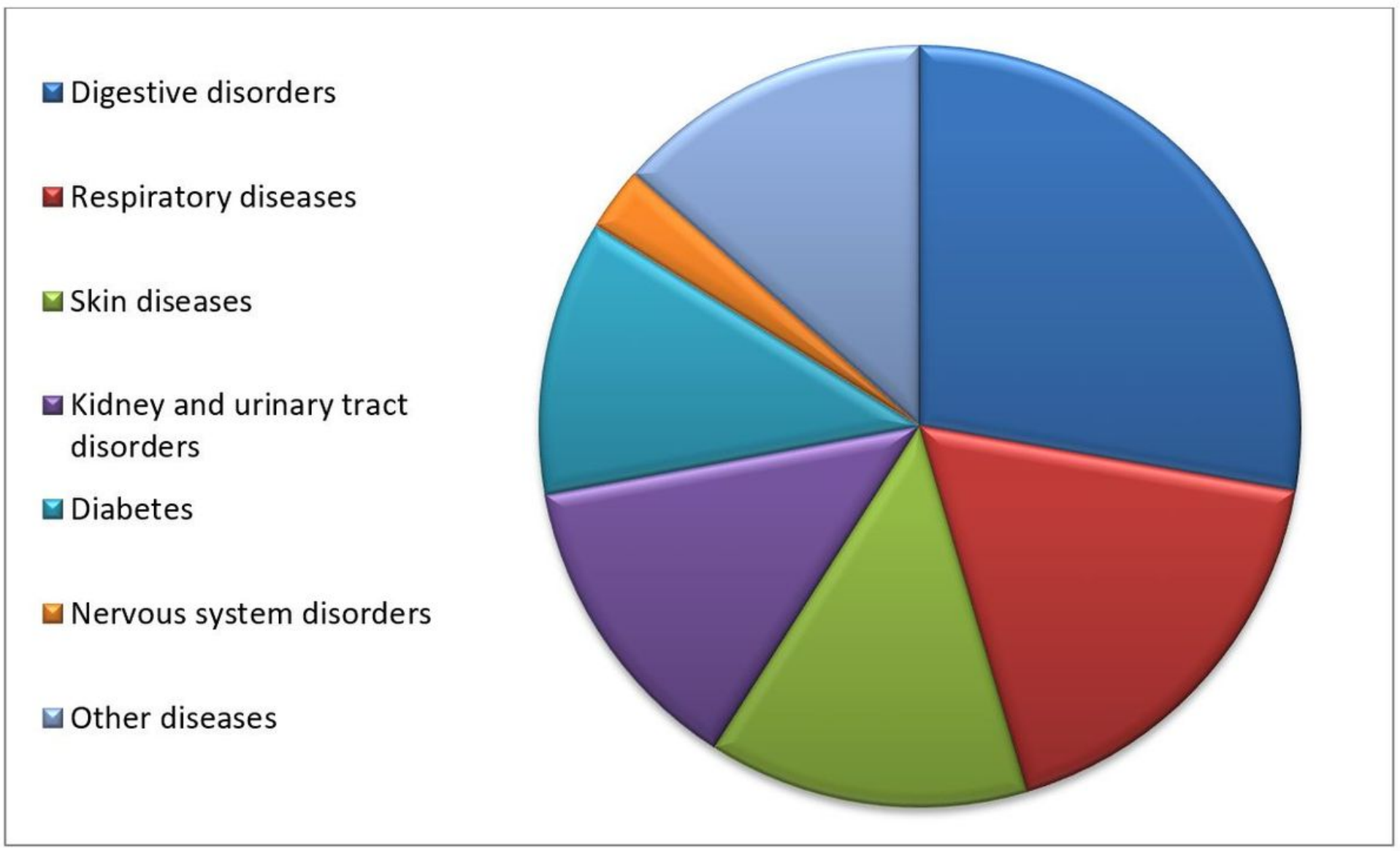

\section{Figure 4}

Ethno medicinal information about treatment the different diseases related to Western region in Syria (Latakia and Tartus).

\section{Supplementary Files}

This is a list of supplementary files associated with this preprint. Click to download.

- SupplementaryMaterial.docx 